FACULDADE DE FILOSOFIA, LETRAS E CIÊNCIAS HUMANAS

DEPARTAMENTO DE LETRAS CLÁSSICAS E VERNÁCULAS

PROGRAMA DE PÓS-GRADUAÇÃO EM ESTUDOS COMPARADOS

DE LITERATURAS DE LÍNGUA PORTUGUESA

\title{
MANUEL BANDEIRA E CLARIDADE: CONFLUÊNCIAS LITERÁRIAS ENTRE O MODERNISMO BRASILEIRO E O CABO-VERDIANO
}

\author{
JÚLIO CESAR MACHADO DE PAULA
}

Dissertação apresentada ao programa de Estudos Comparados de Literaturas de Língua Portuguesa do Departamento de Letras Clássicas e Vernáculas da Universidade de São Paulo como parte dos requisitos exigidos para a obtenção do grau de Mestre.

Orientador: Prof. Dr. Hélder Garmes

Co-orientador: Prof. Dr. Rubens Pereira dos Santos 
UNIVERSIDADE DE SÃO PAULO

FACULDADE DE FILOSOFIA, LETRAS E CIÊNCIAS HUMANAS

DEPARTAMENTO DE LETRAS CLÁSSICAS E VERNÁCULAS

PROGRAMA DE PÓS-GRADUAÇÃO EM ESTUDOS COMPARADOS

DE LITERATURAS DE LÍNGUA PORTUGUESA

\section{MANUEL BANDEIRA E CLARIDADE: CONFLUÊNCIAS LITERÁRIAS ENTRE O MODERNISMO BRASILEIRO E O CABO-VERDIANO}

JÚLIO CESAR MACHADO DE PAULA

São Paulo

2005 
Ficha catalográfica elaborada pelo Serviço de Biblioteca e Documentação da Faculdade de Filosofia, Letras e Ciências Humanas da Universidade de São Paulo.

P324 Paula, Júlio Cesar Machado de

Manuel Bandeira e Claridade: confluências literárias entre o modernismo brasileiro e o cabo-verdiano. / Júlio Cesar Machado de Paula ; orientador Hélder Garmes ; co-orientador Rubens Pereira dos Santos. -- São Paulo, 2005.

$130 \mathrm{f}$.

Dissertação (Mestrado - Programa de Pós-Graduação em Estudos Comparados de Literaturas de Língua Portuguesa ) - Faculdade de Filosofia, Letras e Ciências Humanas da Universidade de São Paulo.

1. Literatura comparada 2. Literatura brasileira 3. Literatura africana - Cabo Verde 4. Literatura de expressão portuguesa 5. Modernismo literatura 6. Manuel Bandeira 7. Revista Claridade I. Título II. Garmes, Hélder III. Santos, Rubens Pereira dos 
FOLHA DE APROVAÇÃO

\section{Júlio Cesar Machado de Paula}

Manuel Bandeira e Claridade: confluências literárias entre o modernismo brasileiro e o cabo-verdiano

Dissertação apresentada ao programa de Estudos Comparados de Literaturas de Língua Portuguesa do Departamento de Letras Clássicas e Vernáculas da Universidade de São Paulo como parte dos requisitos exigidos para a obtenção do grau de Mestre.

Aprovado em:

\section{Banca Examinadora}

Nome:

Instituição:

Assinatura:

Nome:

Instituição:

Assinatura:

Nome:

Instituição:

Assinatura: 
Dedico este trabalho a meus pais, João Batista e Regina Célis; a minha avó, Nazareth; e à copiosa Irmandade dos Machados de Paula. 


\section{AGRADECIMENTOS}

Aos meus orientadores:

Rubens Pereira dos Santos, pelo exemplo humano demonstrado em sua dedicação incondicional ao aluno;

e Hélder Garmes, que acolheu-nos nessa empreitada, matriz, espero, mais do que de um relacionamento acadêmico, de uma longa amizade.

À professora Norma Seltzer Goldstein, primeira orientadora, pelo inquebrantável incentivo e pela confiança depositada em meu trabalho, acadêmico ou literário, desde o primeiro momento; e pela participação, rica, como sempre, na Banca de Qualificação desta pesquisa.

À professora Benilde Caniato, pelo profundo conhecimento das questões caboverdianas e pela disposição em compartilhá-lo na Qualificação deste trabalho.

À CAPES, Coordenadoria de Aperfeiçoamento de Pessoal de Nível Superior, pela Bolsa de Mestrado que possibilitou-me dispor de tempo para a realização das pesquisas.

A Márcia e Creusa, do Centro de Estudos Portugueses, e Jacó, da Secretaria de Pós-graduação do DLCV, nossos fidelíssimos escudeiros. 


\section{RESUMO:}

PAULA, J. C. M. Manuel Bandeira e Claridade: confluências literárias entre o Modernismo brasileiro e o cabo-verdiano. São Paulo, 2005, 130 p. Dissertação (Mestrado). Departamento de Letras Clássicas e Vernáculas. Universidade de São Paulo.

Este trabalho analisa a importância da poesia de Manuel Bandeira, dentro do contexto do Modernismo literário brasileiro, para o grupo de autores cabo-verdianos ligados à publicação da revista Claridade, sobretudo em sua primeira fase, nos anos de 1936 e 1937. Destacamos aspectos que contribuíram para a confluência literária que se verifica entre tais autores, como a similaridade das formações culturais, a busca por um modernismo que servisse de transição entre a herança literária do passado e as inovações formais, e o caráter utópico da literatura. Como conclusão, esperamos contribuir para uma nova leitura da obra do poeta brasileiro, enaltecendo aspectos até então relegados a um segundo plano, e, como conseqüência, promover uma valorização dos autores cabo-verdianos como agentes no vasto sistema das literaturas de língua portuguesa.

PALAVRAS-CHAVE: comparatismo literário; Manuel Bandeira; Literatura cabo-verdiana; Revista Claridade; modernismo.

\section{ABSTRACT:}

PAULA, J. C. M. Manuel Bandeira and Claridade: literary confluences of Brazilian and Cape Verdean Modernism. São Paulo, 2005, 130 p. Dissertation (Master). Departament of Classical and Vernacular Languages. University of São Paulo.

This work analyzes the importance of Manuel Bandeira's poetry, in the context of Brazilian literary Modernism, for the group of Cape Verdean authors responsible for the publication of Claridade magazine, especially in its first phase, in 1936 and 1937. Emphasis is given to some aspects that contributed to the literary confluence existent between these authors, such as the similarities of cultural formation, the quest for a Modernism that could function as a bridge between the literary heritage and the formal esthetic innovation, and the utopian nature of the literature. The intention is to contribute to a new reading of the Brazilian poet, stressing aspects that were relegated to the background, and, as a result, promoting a valorization of the Cape Verdean authors as agents in the vast system composed of all literatures written in the Portuguese language.

Keywords: literary comparatism; modernism; Manuel Bandeira; Cape Verdean literature; Claridade magazine. 


\section{SUMÁRIO}

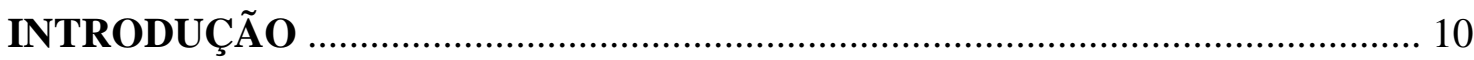

CAPÍTULO 1: O PERCURSO CRÍTICO ........................................................... 13

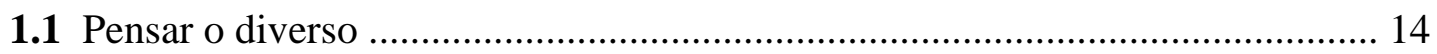

1.2 Abolir o centro - uma poética da relação ……................................................ 15

1.3 Do exílio à errância - Cabo Verde 'entre-dois-mundos' .....................................16

1.4 Do despertar da consciência crítica à construção de homens novos ................. 19

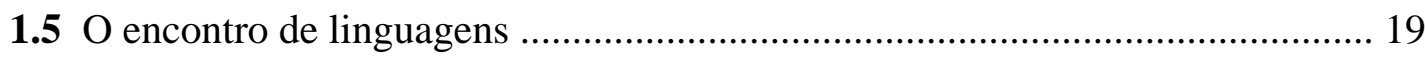

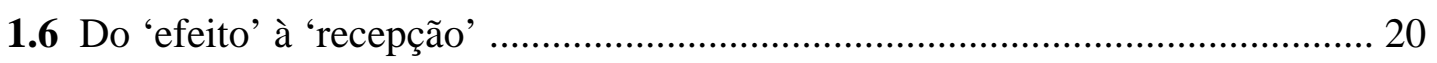

CAPÍTULO 2: ANTES DOS PAIS, OS MESMOS AVÓS ..................................... 23

2.1 A originalidade crioula ou "o salão de sangues misturados" .......................... 24

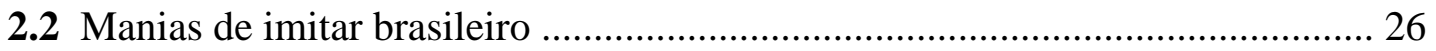

2.3 A presença de Gilberto Freyre e o sentimento (equivocado) do Brasil ............. 31

CAPÍTULO 3: O MODERNISMO COMO PROCESSO DE TRANSIÇÃO ........ 37

3.1 Simbolismo - Penumbrismo - Modernismo: caminhos da transição ................. 39

3.2 Entre necessária e maldita, a herança do passado ........................................... 42

3.3 Da meia-luz à Claridade: a transição cabo-verdiana para o modernismo ......... 47

3.4 A busca pela "unidade de imaginação" ............................................................. 52

\section{CAPÍtULO 4: DE TERRA-LONGE A PASÁRgADA: A SUPRESSÃo}

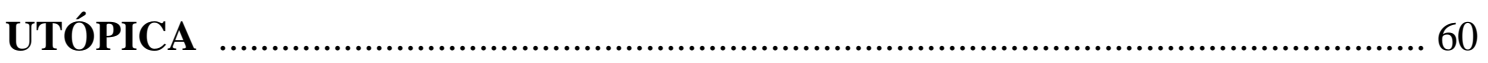

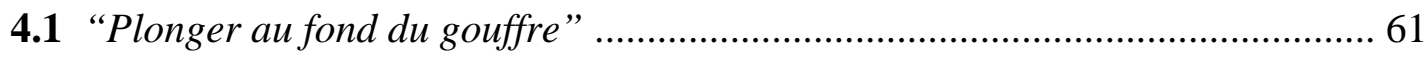

4.2 Mímica do ausente: o caráter supressivo da utopia ...................................... 61

4.3 Saudades de amanhã: utopia como negação do presente ................................. 64

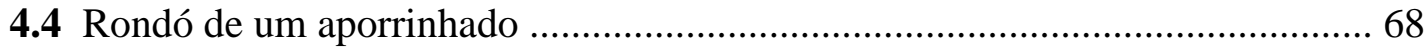

4.5 Da utopia pessoal à res publica …................................................................... 70

4.6 O mito de Pasárgada em Cabo Verde ............................................................. 72

4.7 Os inimigos do rei: poesia engajada e antipasargadismo ................................ 75 
5.1: Bandeira e Jorge Barbosa: discursos da humildade ........................................ 80

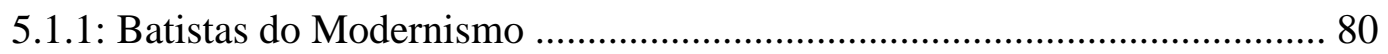

5.1.2: Estratégia da simplicidade: significar o insignificante ............................ 83

5.1.3: Ocorrência em Birmingham e uma notícia de jornal ............................... 87

5.2: Bandeira e Osvaldo Alcântara: poéticas do alumbramento .............................. 91

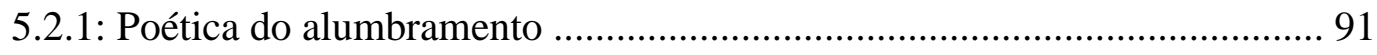

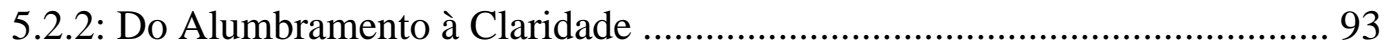

5.2.3: "Evocação do Recife" e "A Serenata" ........................................................ 95

5.2.4: Futuro do pretérito ............................................................................... 102

5.2.5: Da evocação inconsciente ao exercício poético ..................................... 103

5.2.6: U-topos: negar o espaço para reconstruí-lo ............................................ 105

5.3: Bandeira e Manuel Lopes: lições de partir ..................................................... 108

5.3.1: Do cisne de veludo... ............................................................................ 109

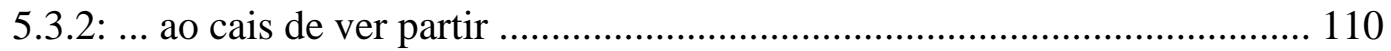

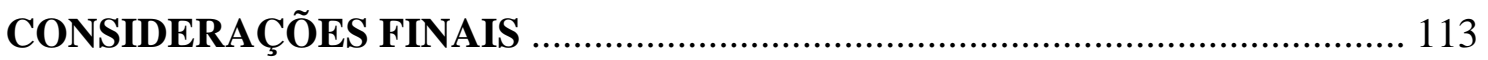

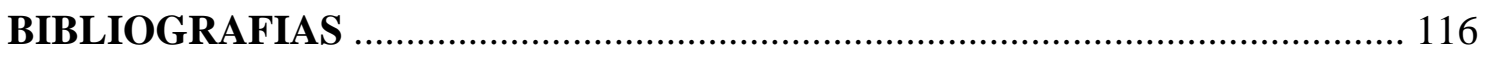

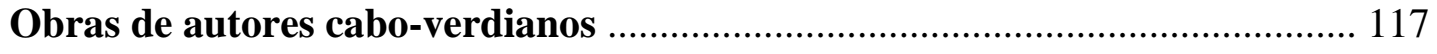

Obras sobre literatura cabo-verdiana e seus autores .................................... 119

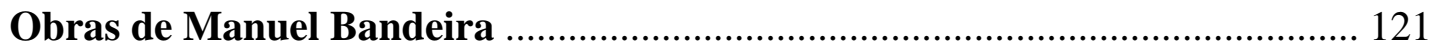

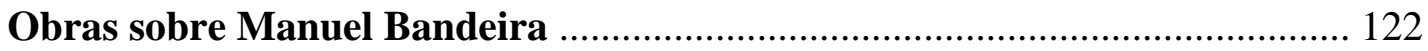

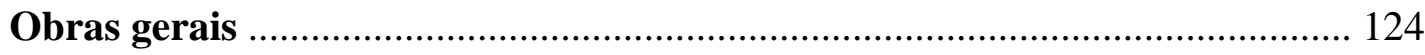


INTRODUÇÃO 
Ao iniciarmos as primeiras buscas bibliográficas para a elaboração do projeto de pesquisa que originou esta Dissertação, pretendíamos desenvolver um trabalho que se centrasse especificamente no estudo da recepção e da reescritura, por parte de um determinado grupo de autores cabo-verdianos, do mito utópico de 'Pasárgada', desenvolvido por Manuel Bandeira a partir do poema "Vou-me embora pra Pasárgada", publicado em 1930 no livro Libertinagem.

No entanto, tão logo fosse nosso trabalho adquirindo profundidade, percebemos que a importância da obra do poeta brasileiro para a literatura cabo-verdiana, sobretudo no momento de afirmação de seu Modernismo e de sua especificidade (publicação de Arquipélago, de Jorge Barbosa, em 1935, e da revista Claridade ${ }^{1}$, no ano seguinte), vai muito além do aproveitamento ou da reescritura de um mito ou de um tema literário específico, independentemente do quanto sua recorrência possa ter criado, entre as duas literaturas, vínculos bastante intensos.

Além das freqüentes referências diretas a Bandeira, pode-se observar uma série de elementos, tanto de natureza sócio-cultural quanto literária, propriamente dita, que confirmam a presença do poeta brasileiro entre seus pares do arquipélago africano e a importância crucial de sua poesia para eles. Evidentemente, tais referências feitas e tais elementos observáveis não são fatos apenas coincidentes ou aleatórios, e pressupõem, por parte dos autores envolvidos, afinidades diversas, experiências, substratos literários comuns, motivações e outros fatores que justificaram uma análise comparativa da questão.

Inicialmente, concentramos nosso trabalho de pesquisa no estudo desses elementos e anseios comuns, essenciais para a aproximação entre duas literaturas. Finda esta etapa, demos início a um trabalho de análises textuais comparatistas com o intuito de demonstrar a importância de determinados recursos estéticos, significativos na obra de Manuel Bandeira, para a literatura dos três principais autores claridosos: Jorge Barbosa, Manuel Lopes e Osvaldo Alcântara (pseudônimo poético de Baltasar Lopes).

Finalmente, invertendo-se o sentido do fluxo de trocas, buscamos verificar como a experiência cabo-verdiana pode ser valiosa como subsídio para uma nova leitura da obra de Manuel Bandeira, atenta a elementos até então despercebidos ou relegados por nós, leitores brasileiros, a um segundo plano.

2 Mais precisamente em sua primeira fase, correspondente aos três números iniciais, publicados entre 1936 e 1937, em intervalos irregulares de aproximadamente seis meses. 
No capítulo 1, "O Percurso Crítico", buscamos traçar as principais linhas teóricas e conceituais que nortearam nosso trabalho e que julgamos serem as mais adequadas para a abordagem do corpus da pesquisa.

No capítulo 2, "Antes dos pais, os mesmos avós", buscamos verificar como as semelhanças de formação entre Brasil e Cabo Verde contribuíram para a aproximação literária de autores de ambos os lados do Atlântico.

No capítulo 3, "O Modernismo como Processo de Transição", estudamos as transformações estéticas graduais que desembocariam, em Cabo Verde, na Claridade, a exemplo do que se dera com Bandeira em seu percurso formador, do penumbrismo de $A$ Cinza das Horas ao modernismo de Libertinagem e Estrela da Manhã.

No capítulo 4, "De terra-longe a Pasárgada: a supressão utópica", discorremos sobre o uso da literatura como instrumento de supressão utópica daquilo de que se foi privado, no plano pessoal, no caso de Bandeira, ou no plano coletivo, no caso dos caboverdianos.

No capítulo 5, "Bandeira entre seus Pares", desenvolvemos leituras paralelas de poemas de Bandeira e de cada um dos três principais autores da Claridade (Jorge Barbosa, Baltasar Lopes/Osvaldo Alcântara e Manuel Lopes) à luz das confluências literárias estudadas nos capítulos anteriores. 


\section{CAPÍTULO 1:}

O Percurso crítico 


\subsection{Pensar o diverso}

Em um campo relativamente novo como o dos Estudos Comparados de Literaturas de Língua Portuguesa, cujas fronteiras multiplicam-se continuamente, expandindo seus domínios em direção a outras áreas do conhecimento, como a Sociologia, a História e a Ciência Política, os trabalhos de pesquisa devem, tanto quanto seja possível, conjugar o conhecimento do corpus definido a teorias e métodos passíveis de serem aplicados a ele.

Benjamin Abdala Jr (2000), ao tentar definir estratégias para uma abordagem adequada de nossas questões literárias, chama nossa atenção para a constituição progressiva de grupos supranacionais, unidos por fatores de diversa natureza, e para a necessidade de se estudá-los de modo conjunto. A esse respeito, ao comentar a pertinência das trocas culturais e dos fluxos literários entre os países de língua portuguesa, Maria Aparecida Santilli valeu-se de uma feliz imagem, comparando a imensa comunidade lusófona a um "sistema de vasos comunicantes" (1985: p. 8), no qual os fluxos literários circulariam por todos os lados, em todos os sentidos, em busca do equilíbrio.

Tendo como objeto de estudo o processo gradual de transformação da poesia cabo-verdiana nas décadas de 1930 e 1940, suportado em grande medida pela leitura de autores brasileiros, desde cedo foi preciso buscar modelos críticos de análise nãoessencialistas, fundados sobre a idéia da diversidade.

Por se tratar de um caso de relacionamento profundo entre duas literaturas nãohegemônicas, descartamos, desde o primeiro momento, os modelos historicistas baseados no estudo de fontes e influências, que ainda hoje encontram adeptos, dentre os quais, o crítico norte-americano Harold Bloom, que neles se apóia para fundamentar sua idéia de cânone ocidental. Deve-se a esse mesmo motivo a preferência pelo termo confluência, utilizado no título desse trabalho, ao invés de influência.

Também os modelos estritamente estruturalistas pareceram-nos insuficientes, uma vez que, reservando um espaço reduzido para os processos históricos, não permitiriam um estudo aprofundado das similaridades de formação e contexto que possibilitaram o desencadeamento do modernismo literário no Brasil e em Cabo Verde.

Dentro dos objetivos a que nos propusemos, pareceu-nos adequado optar por uma linha teórica que se aproximasse da estética da recepção, permitindo uma abordagem que levasse em conta não apenas os recursos formais utilizados para a 
produção literária, mas o contexto histórico-cultural que desencadeia e no qual se processa tal produção. Além disso, a distinção feita por Jauss entre efeito e recepção, propriamente dita, como veremos ao fim desse capítulo, mostrou-se bastante funcional em nosso intuito de abordar os autores cabo-verdianos como agentes nos processos literários do macrossistema de língua portuguesa.

\subsection{Abolir o centro - uma poética da relação}

Contra a abordagem essencialista das culturas, vários autores começaram a destacar, a partir de meados do século XX, a idéia de que os valores culturais são, na verdade, intercambiáveis, criando, em certa medida e ao revés da estandardização econômica operada pelo que discutivelmente se convencionou chamar de globalização, condições para o surgimento de culturas híbridas, sobretudo nos espaços pós-coloniais.

Gruzinski reage contra o que considera "enfoques dualistas e maniqueístas" (2001, p. 48), cuja intenção seria negar os trânsitos culturais e as comunidades heterogêneas surgidas a partir deles. Diz ele: "Como demonstram inúmeros exemplos, uma fronteira costuma ser porosa, permeável, flexível: desloca-se e pode ser deslocada." (2001, p. 48). Valendo-se de imagens semelhantes, García Canclini defende a capacidade criativa e criadora da "porosidade das fronteiras" e dos "fluxos multidirecionais" (2000, p. 122).

No afã de se obter uma autonomia cultural e literária, operou-se uma busca pelo que Rama designou de "discurso lingüístico homologante" (2001, p. 219), a se construir a partir da elaboração literária de variantes lingüísticas locais. No Brasil, o uso de tais registros deixa de ser um adorno regional, como se vê nas primeiras décadas do século XX na prosa rebuscada de Affonso Arinos ou Coelho Neto, dentre outros, para ser incorporada à literatura, no Modernismo, como fundamento da escrita, enriquecida, igualmente, com o falar cotidiano dos centros urbanos que então se encorpavam. Em Cabo Verde, o crioulo (ou língua cabo-verdiana, como mais tarde se diria), idioma cotidiano do país, foi enaltecido pelos claridosos, que dele fizeram uso desde a primeira página de Claridade, revista literária que, em 1936, inaugura o modernismo literário no arquipélago.

A valorização de línguas ou registros lingüísticos locais, alçadas à condição de mananciais dignos de aproveitamento para a produção literária, funcionou (e funciona) 
como um dispositivo de resistência ao "eixo vertical do poder cultural" (HALL, 2003, p. 60), promovendo as "modernidades vernáculas" e, à revelia do processo global de homogeneização, uma "proliferação subalterna das diferenças".

Glissant, em oposição aos modelos (hegelianos, sobretudo) construídos a partir de relações binárias de exclusão (presença/ausência; fundo/forma; natureza/cultura etc.), propõe, valendo-se do conceito de différance (DERRIDA, 1972), a busca de um modelo múltiplo e móvel, adequado a um mundo que se compõe cada vez mais de culturas igualmente múltiplas e móveis, ou, como ele prefere chamar, compósitas. Multiplicidade e movimento pressupõem, para Glissant, um novo modelo de enraizamento cultural, sintetizado por Deleuze e Guattari (1995, p. 32) pela imagem do rizoma (rhizome), estrutura vegetal composta por raízes múltiplas que se espalham por várias direções, permitindo a absorção de elementos igualmente vários. Em oposição a uma identidade de raiz-única, cuja definição prescinde de qualquer alteridade, cada elemento do rizoma não pode ser definido senão pelas relações que estabelece com os demais, o que levou Glissant a imaginar uma "poética da relação" (1990) ou uma "poética do diverso" (1996).

Para Glissant, a circulação das "palavras poéticas” (1990, p. 41) entre espaços originalmente considerados periféricos seria responsável por uma espécie de abolição da idéia de centro, permitindo ou mesmo estimulando novas rotas de intercâmbio cultural em cujo itinerário não mais se incluía, necessariamente, a mediação das antigas metrópoles européias.

\subsection{Do exílio à errância - Cabo Verde 'entre-dois-mundos'}

Glissant (1990, p. 27) propõe ainda, como estratégia discursiva dos que estão à margem, a substituição da "experiência do exílio", associada à escravidão e ao trabalho forçado, e cujos efeitos extremos seriam a destruição da memória e, conseqüentemente, da linguagem, por uma "experiência da errância", na qual o deslocamento, longe de promover um esfacelamento cultural, instaura a própria cultura pela manutenção, entre os indivíduos, de um imaginário comum.

Entendemos que, no caso de Cabo Verde, país que, ainda hoje, experimenta a condição sui generis de ter aproximadamente dois terços de sua população dispersos 
pelo mundo, a passagem de uma experiência do exílio para uma experiência da errância poderia constituir uma estratégia de sobrevivência cultural e de resistência ao que Hall chamou de "conceito fechado de diáspora" (2003, p. 33), fundado "sobre a construção de uma fronteira de exclusão".

Pensando na originalidade da formação crioula e no papel de entreposto desde cedo exercido pelas ilhas, isto é, no fato de serem, secularmente, um lugar de passagem e elo de comunicação entre outros espaços, Manuel Ferreira avalia a designação que muitas vezes se fez do cabo-verdiano como um "homem-de-dois-mundos" (1975, p. 40). O termo, comum em outros lugares do continente africano, foi usado em Cabo Verde para designar os ilhéus de educação européia, os quais, ao aculturar-se, abrindo mão ou mesmo repudiando os elementos africanos de suas origens, demonstrariam, aos olhos da metrópole, sua capacidade de civilização.

Por trás de tal idéia, colonialista, afinal, esconde-se o princípio absurdo de que os valores europeus de cultura seriam universais, devendo, portanto, ser adotados como norma, em detrimento de qualquer diversidade.

Em oposição, Ferreira propõe o termo "homem-de-entre-dois-mundos", resultado não de um processo aculturador, em que se esfumariam os valores africanos diante de uma suposta superioridade cultural européia, mas de um processo de transculturação, pelo qual grupos distintos concorreriam mutuamente para a formação de uma cultura original.

Utilizado por Ferreira em passagens distintas de Aventura Crioula, o termo transculturação foi cunhado pelo sociólogo cubano Fernando Ortiz (1963) para descrever, pelo viés econômico, o processo original de formação da sociedade cubana, em que tomaram parte elementos distintos, oriundos, por um lado, da cultura européia do açúcar, incubada nas ilhas atlânticas, e, por outro, da cultura ameríndia do tabaco. Ortiz chegou à conclusão de que não ocorrera (como pretendiam não poucos etnocentristas) uma suplantação das culturas pré-existentes, mas o surgimento de outras, engendradas pela rearticulação de diversos substratos, reelaborados dinamicamente pelos grupos nativos, e pela transitividade dos valores culturais, evocada pela pelo radical comum 'trans-'. 


\subsection{Do despertar da consciência crítica à construção de homens novos}

Em seu estudo sobre a poesia de Manuel Bandeira, Davi Arrigucci Jr (1992) atenta-nos para o fato de que uma das características vitais da literatura no século XX foi o desenvolvimento de uma consciência crítica que, sob formas variadas, incorporouse aos projetos de construção das próprias obras.

Também em Cabo Verde é possível observar a interpenetração de teoria crítica e obra literária. Cientes da necessidade de conjugarem suas obras a teorias que lhes dessem sustentação, os claridosos reservaram em sua revista o devido espaço para artigos de natureza ensaística.

Uma das principais tarefas a que se propunham era justamente a de voltar suas atenções para a realidade original da formação crioula cabo-verdiana, até então menosprezada pela visão eurocêntrica do colonizador, que "gozou por três mil anos do privilégio de ver sem ser visto." (SARTRE, 1948, p. IX). Não por acaso, a mais importante seção ensaística da Claridade, assinada por ninguém menos que Manuel Lopes, recebeu o nome de "Tomada de Vista", uma verdadeira tomada de posição no processo de visualização de si e de seu próprio espaço, tarefa imprescindível para a emancipação literária.

Mesmo se tratando ainda de uma espécie de "nacionalismo sem nações"2 (BONNAFFÉ, 1964, p. 52), o trabalho iniciado por esse grupo de autores, visando à criação de um sistema autônomo, não apenas literário, mas de pensamento, pode ser entendido como uma conscientização cultural que, por criar uma nova mentalidade intelectual em Cabo Verde, desencadeia seu processo de descolonização, já que "a descolonização é, em verdade, criação de homens novos." (FANON, 1968, p. 26)

Evidentemente, todo esse processo estaria inconcluso se se esgotasse na criação pura e simples de homens novos. Seria preciso, em seguida, que eles se organizassem em grupos, buscando uma unidade de classe que lhes permitisse enfrentar os valores hegemônicos impostos pela ordenação colonial. A idéia de que essa unidade de classe deve ser construída é partilhada também por Hall, que se dedica ao assunto ao analisar os Cadernos do Cárcere de Gramsci. Para Hall:

a chamada 'unidade de classe' nunca é pressuposta, a priori. Compreende-se que as classes, ao mesmo tempo em que compartilham certas condições

\footnotetext{
${ }^{2}$ Ou ainda, segundo esse mesmo autor, de "nacionalismos de caráter 'projetivo'."
} 
comuns de existência, também são perpassadas por conflitos de interesses, historicamente segmentadas e fragmentadas no curso real da formação histórica. (2003, p.310)

E destaca, ainda, a importância dessa unidade de classe na superação de modelos ideológicos anteriores ao novo momento histórico a que se pretende dar início.

O que importa é a crítica à qual esse complexo ideológico será sujeitado pelos primeiros representantes da nova fase histórica. Essa crítica possibilita um processo de diferenciação e mudança no peso relativo que os elementos ideológicos anteriores possuíam. (2003, p. 288)

Em Cabo Verde, como na África, de um modo geral, é significativo o fato de esse processo se dar, antes de tudo, em um grupo literário. Para Bakhtin (1997), a ideologia é um fenômeno cuja construção se dá no âmbito da linguagem, e, como tal, está sujeita a flutuações de sentido que lhe são naturais. Por trás disso tudo está, naturalmente, uma crítica à concepção da linguagem oriunda da lingüística saussureana, para a qual a língua (langue) já traria em seu bojo todas as possibilidades de construção concretizadas no momento da fala (parole). Um determinismo lingüístico compatível com o que Hall chama de "metáfora clássica de transformação" e que receberia, na década de 1950, críticas efusivas de autores da Nova Esquerda (New Left $)^{3}$, insatisfeitos com a polarização maniqueísta entre base e superestrutura construída pelo chamado Marxismo clássico.

\section{$1.5 O$ encontro de linguagens}

Se entendermos o movimento da Claridade como uma resposta de seus autores ao que Rama chamou de "impacto modernizador" (2001, p. 213), veremos que o papel dos claridosos assemelha-se ao de escritores latino-americanos classificados pelo crítico uruguaio como transculturadores, como Rulfo, Arguedas, Guimarães Rosa e Garcia Márquez, "criadores literários que constroem as pontes indispensáveis para resgatar as culturas regionais" (2001, p. 213). Essa seria, ante o mencionado impacto modernizador, a resposta da "plasticidade cultural" (RAMA, 2001, p. 214), em que 
haveria, entre os dois lados envolvidos, uma troca de valores, ao invés de uma imposição aculturadora por parte do dominador ou de um encasulamento dos grupos dominados, cujas manifestações culturais correriam o risco de perder sua vitalidade dinâmica, tornando-se peças folclóricas estéreis. O próprio Baltasar Lopes vale-se da imagem da plasticidade ao definir o papel de mediador cultural que Chiquinho, personagem de seu romance homônimo, assume ao postar-se entre a herança tradicional da oralidade e o universo dos emigrados, cujas cartas o menino letrado lia aos demais. Diz o protagonista: "Eu era matéria plástica que se submetia a todas as experiências. E todas me iam deixando seu depósito de sabedoria e perversão.” (1986, p. 67).

\subsection{Do 'efeito' à 'recepção'}

Em Para uma Estética da Recepção, Jauss busca distinguir duas formas distintas de se abordar a reação dos leitores à obra literária. Uma, herança das análises positivistas, que, aplicando à literatura um "princípio de explicação puramente causal, assinalaram apenas determinismos extrínsecos às obras" (1978, p. 29), destacaria o efeito (wirkung), que, determinado unilateralmente, teria como único agente o autor, cuja enunciação partiria, sempre, de uma literatura hegemônica. Outra, enaltecendo o papel construtivo dos leitores, estaria centrada na recepção propriamente dita, em que um destinatário ativo apropriar-se-ia do discurso que recebe para produzir, em sequiência, seu próprio discurso, tornando-se um dos agentes do processo literário, que se torna interativo, circular.

Esse segundo modo de abordagem, ao romper com a idéia de linearidade das trocas literárias, confere aos autores que escrevem a partir das margens do sistema um grau de importância equivalente ao dos que o fazem a partir dos espaços hegemônicos. Dessa forma, experimenta-se uma (re)inscrição das sociedades não-européias no processo histórico global, no qual afirmam-se como agentes.

Mais do que um mero dispositivo analítico, o cruzamento dos eixos sincrônico e diacrônico estaria na base constitutiva essencial da própria literatura:

O que faz com que a literatura seja a literatura, sua 'literariedade', não se define apenas em sincronia, pela oposição da linguagem poética e da

\footnotetext{
${ }^{3}$ Stallybrass e Allon White, dentre outros; a esse respeito, ver HALL, 2003, pp. 219-244.
} 
linguagem prática, mas também em diacronia, pela oposição formal sempre renovada entre as obras novas e as que as precederam na 'série' literária. (JAUSS, 1978, p. 41). ${ }^{4}$

E, adiante:

\begin{abstract}
A literatura, como continuidade coerente de eventos, constitui-se apenas no momento em que se torna objeto da experiência literária dos contemporâneos e da posteridade _ leitores, crítica e autores, segundo o horizonte de expectativas que lhes é próprio. (JAUSS, 1978, p. 48-49).
\end{abstract}

Starobinski, prefaciando o estudo de Jauss, afirma que a literatura passa a fazer parte do processo histórico concreto apenas pela mediação que se estabelece entre a produção das obras e sua acolhida, incluindo-se, nesse processo, o julgamento dos textos, sua seleção e preservação pela memória ou seu esquecimento. Dessa forma, os leitores passam a "adotar o papel ativo que consiste em responder a uma tradição, produzindo obras novas." (apud JAUSS, 1978, p. 10).

No mesmo prefácio, insistindo em um mecanismo de questões e respostas, Starobinski passa da produção, propriamente dita, para a crítica literária, em busca de uma metodologia reativa de abordagem, partindo do princípio de que

Toda obra é resposta a uma questão, e a questão que o intérprete, por sua vez, deve fazer, consiste em reconhecer, no texto da obra e por meio dele, qual foi a questão inicialmente feita e como foi articulada a resposta." (apud JAUSS, 1978, p. 17).

Pensando-se nisso e no objeto de estudo que tínhamos ao iniciarmos o presente trabalho, formulamos uma dupla questão, cujas respostas deveriam nortear nossa pesquisa: Que leitura fizeram, da poesia de Manuel Bandeira, os autores da primeira fase da Claridade? E, a partir dessa leitura, como foram capazes de responder, ativamente, produzindo literatura, ao invés de simplesmente recebê-la da Europa ou mesmo do Brasil?

Ao buscar respostas para tais questões, buscamos fazê-lo sem entender as relações literárias que se estabeleceram entre o modernismo brasileiro e o cabo-verdiano como uma mera mudança de órbita, como se os autores ilhéus, deixando de lado o uso

\footnotetext{
4 Jauss parece desenvolver o que Jakobson (1969, pp. 118-162) propusera, no plano lingüístico, em "Lingüística e Poética"; para o lingüista, no cruzamento de um eixo sincrônico, da similaridade,
} 
passivo de modelos eurocêntricos, lançassem mão, de modo igualmente passivo, de modelos brasileiros.

fundamento da metáfora, e de um eixo diacrônico, da contigüidade, fundamento da metonímia, residiria a função poética da linguagem. 


\section{CAPÍTULO 2:}

Antes dos pais, os mesmos avós

"Eu gosto de Você, Brasil,

porque Você é parecido com a minha terra."

(Jorge Barbosa)

"De fato este salão de sangues misturados parece o

Brasil...”

(Manuel Bandeira) 


\title{
2.1 A originalidade crioula ou "o salão de sangues misturados"
}

Desabitadas quando os portugueses pela primeira vez ali aportaram, as ilhas de Cabo Verde desde cedo desempenharam um importante papel econômico como entrepostos comerciais, favorecendo o surgimento de uma sociedade crioula. Diferentemente das regiões ocupadas pelos portugueses no continente, nas quais os contatos limitaram-se, até o século XIX, a uma estreita faixa litorânea, os processos de crioulização em Cabo Verde espraiaram-se desde muito cedo pelo arquipélago, criando fortes vínculos entre mestiçagem e identidade local.

\begin{abstract}
Houve deslocamentos populacionais em Angola, Moçambique e na GuinéBissau tanto dentro quanto fora destes territórios, mas o desenraizamento e a transplantação dos povos que construíram a preponderância numérica da população do arquipélago não puderam deixar de resultar num processo de aculturação mais rápido e mais profundo em Cabo Verde do que nas colônias situadas no continente africano. (HAMILTON, 1984, p. 93).
\end{abstract}

Nas regiões que constituiriam as colônias do continente, embora também se verificassem, inevitavelmente, processos de crioulização, estes se concentravam nos núcleos urbanos nascentes, não tendo suficiente expressão para fazer surgir, a partir da mestiçagem, identidades angolanas ou moçambicanas, por exemplo. ${ }^{5}$

Aliado a sucessivas crises econômicas (declínio da produção agrícola nos decênios de 1860 e 1870, abolição da escravatura, decadência do porto de Mindelo) e ao descaso da metrópole, o posicionamento geográfico do arquipélago, distante da costa e parcialmente isolado do resto do mundo, levou à irrupção precoce, se comparada às demais colônias portuguesas, de um sentimento de nativismo e identidade, amalgamados por manifestações mescladas de cultura, como a morna e o idioma crioulo, em cuja constituição tomavam parte tanto elementos europeus quanto africanos.

Para Manuel Ferreira, o sentimento de "intersecção entre África e Europa e entre nacionalidade e supranacionalismo português" (1985, p. 100) faria do intelectual caboverdiano um "homem-de-entre-dois-mundos" (1975, p. 40), dividido entre um “europeísmo arraigado" (1985: p. 100), absorvido, em geral, pela formação clássica dos liceus, e a aceitação dos africanismos, que, afinal, diferenciam-no dos portugueses,

\footnotetext{
${ }^{5}$ Para Orlando de Albuquerque (1976), os processos de formação cultural e identitária nas ilhas e no continente seriam diferentes a ponto de exigirem nomes distintos. Para ele, o "crioulismo" seria observável em Cabo Verde, mas não em Angola e Moçambique, exemplos de "mulatismo".
} 
inclusive dos também ilhéus da Madeira ou dos Açores. Ambivalência definida em verso por Jorge Barbosa no poema significativamente intitulado "Povo":

\author{
Conflito numa alma só \\ de duas almas contrárias \\ buscando-se, almalgamando-se \\ numa secular fusão \\ (...) \\ N'alma do povo ficou \\ esta ansiedade profunda \\ - qualquer coisa de indeciso \\ entre o clima tropical \\ e o espelho de Portugal...
}

(BARBOSA, 2002, p. 46)

No romance Chiquinho, em que o autor, Baltasar Lopes, busca reconstituir, conforme declarou em entrevista a Michel Laban, o ambiente em torno dio qual constituiu-se o grupo da Claridade, é possível encontrar essa imagem de uma identificação ambivalente, construída por intersecções de fragmentos europeus e africanos. Incumbido pelos amigos do Grêmio de compor um ensaio sobre a vida social de sua ilha de origem, São Nicolau, o protagonista Chiquinho sai em busca de fontes documentais. Não as encontrando, lança-se por conta própria numa investida arqueológica cujos resultados são um amontoado de cacos e fragmentos:

Os documentos antigos, desaparecidos. Tudo queimado nas agitadas peripécias da vida passada de S. Nicolau. A história da minha ilha ficava sem base documental. Fiz uma excursão ao Porto da Lapa, onde, segundo a tradição, se fixara o primeiro povoado da ilha. Levei pá e enxada para as escavações. Muitos ficaram desconfiando de tesouros enterrados em potes de barro, como se referia nas histórias de assombrações das casas antigas. Cacos de louça de Lisboa, fragmentos de cantaria do Reino, um esboço de povoado, tudo mandei para o grupo, ao cuidado de Andrezinho. (1986, p. 152). 
Curiosamente, durante o período de atividade intelectual no Grêmio, Chiquinho sente-se atraído (e tem plena consciência disso, já que o declara) por autores cujos temas apontam, recorrentemente, para uma idéia de desagregação:

\begin{abstract}
Atraíam-me principalmente os autores em que o desarticulado do estilo põe na emoção um estremecimento mórbido de neurose. Fialho era o meu deus. Ainda hoje tenho na alma o travo do respeito religioso que me invadia quando eu penetrava na prosa do Cancro. Aquele final de Fialho, em que o cancro transforma a beleza da heroína num fruto podre, cadaverizando-lhe a vida lentamente, por entre paixões e festas, num inferno pavoroso de agonias, ficava-me bulindo cá dentro, como modelo inultrapassável de expressão de certos enigmáticos. (1986, p. 81).
\end{abstract}

Naturalmente, uma identidade que se busca construir a partir de fragmentos que se desagregam e se reordenam continuamente jamais encontrará uma representação definitiva. Pelo contrário, estará em constante processo de significação, pois "O híbrido não é a marca deixada pela continuidade da criação. É o produto de um movimento, de uma instabilidade estrutural das coisas.” (GRUZINSKI, 2001, p. 179).

\title{
2.2 Manias de imitar brasileiro
}

"Bô sabe, cabo-verdiano sempre teve manias de imitar brasileiro".

(Manuel Ferreira)

No verso final do poema "Presença de Gilberto Freyre" (apud FERREIRA, 1975, p. 145), do qual se extraiu o título deste capítulo, Guilherme Rocheteau, tomando a si mesmo e a Gilberto Freyre como exemplos, sintetiza, numa construção metonímica, a similar formação de suas respectivas culturas. De fato, dos países africanos que estiveram colonialmente subjugados a Portugal, Cabo Verde é, étnica e culturalmente, o que mais se assemelha ao Brasil. Tal semelhança, que sempre se evidencia nos trabalhos comparatistas sobre os dois países, cuidou para que surgisse, quer literária, quer culturalmente, uma relação de fraternidade entre Brasil e Cabo Verde, inúmeras vezes evocada por autores diversos e presente também na tradição popular, que cunhou a expressão "nôs irmão" para designar os brasileiros. 
Quando os escritores cabo-verdianos, às vésperas da Claridade, propuseram-se a criar uma literatura de emancipação, fundamentada sobre bases culturais originalmente cabo-verdianas, viram-se divididos entre o substrato paternalista português, imposto pela própria condição colonial, e o substrato de uma África materna mítica e simbólica, intangível, perdida na noite dos tempos. Como síntese entre um e outro referencial, descobriram, por essa altura, a voz ou as vozes do "irmão mais velho", em expressão de Baltasar Lopes.

Neste cenário de afinidades fraternas, a literatura modernista brasileira acabaria por ocupar o lugar em que antes se assentava a literatura portuguesa, representada no arquipélago, às vésperas da publicação da Claridade, sobretudo pela revista Presença. Sobre essa mudança de eixo, pronunciou-se José Osório de Oliveira em seu artigo "Palavras sobre Cabo Verde para serem lidas no Brasil":

\footnotetext{
Os cabo-verdianos precisavam dum exemplo que a literatura de Portugal não lhes podia dar, mas que o Brasil lhes forneceu. As afinidades existentes entre Cabo Verde e os Estados do Nordeste do Brasil predispunham os caboverdianos para compreender, sentir e amar a nova literatura brasileira. Encontrando exemplos a seguir na poesia e nos romances modernos do Brasil, sentindo-se apoiados, na análise do seu caso, pelos novos ensaístas brasileiros, os cabo-verdianos descobriram o seu caminho. (CLARIDADE, 1936, p. 4)
}

Não se tratou, evidentemente, de uma imitação meramente passiva, mas de uma reação produtiva diante das semelhanças observadas entre a realidade brasileira, que se mostrava apta a fomentar uma literatura emancipada, e a cabo-verdiana, desejosa de enveredar pelas mesmas sendas.

Baltasar Lopes, discorrendo sobre o período de formação do grupo da Claridade, reconhece, dada a escassez de meios, a necessidade de se valer de "certezas sistemáticas que só podiam vir, como auxílio metodológico e como investigação, de outras latitudes." (LOPES, 1956, p. 5). E o auxílio viria, como o próprio Lopes explicita adiante, da leitura de obras brasileiras, muitas das quais, como as de Bandeira, evidenciavam a semelhança existente entre os dois países. Diz Lopes sobre o pernambucano: "Em poesia foi um alumbramento a 'Evocação do Recife', de Manuel Bandeira, que, salvo um ou outro pormenor, eu visualizava com as suas figuras dramáticas na minha Ribeira Brava." (1956, p. 5) 
A mesma similaridade seria descrita por Manuel Lopes como um caso de "ressonância", fruto "de um encontro repercussivo de determinantes rácicos", cujos "elementos formativos comuns provieram, em grande parte, de fontes quase idênticas." (1959, p. 14). Jorge Barbosa, também destacando as semelhanças de formação, enaltece a absorção, por parte dos cabo-verdianos, do gesto brasileiro de voltar-se para os valores locais. Diz ele:

Tal influência resultou sobretudo do exemplo dos escritores brasileiros ao se debruçarem sobre sua terra natal e sobre a gente irmã, onde foram encontrar os temas de suas obras. Deles aproveitamos, pois, a descoberta e a experiência, que nos contagiaram com seu entusiasmo de coisa nova. (1953, p. 23).

Entusiasmo que, associando emancipação cultural e literatura, isto é, arte produzida com palavras, levaria, inevitavelmente à questão da língua. Mais do que um mero capricho expressivo, dispor de seu próprio registro lingüístico e dele valer-se para a produção literária era afirmar a própria emancipação enquanto povo. "Povos diferentes, língua diferente, literatura diferente" (apud TELLES, 1982, p. 327), sintetizou Monteiro Lobato em uma fórmula didática.

A esse respeito, qual deveria ser a língua literária cabo-verdiana, capaz de afirmar, por si só, a própria emancipação diante do sistema metropolitano? O português, que, apesar do ranço colonial, propiciaria uma maior exposição dos autores para além das fronteiras estreitas do arquipélago, ou o crioulo dos "nominhos", falado cotidianamente e veículo de expressão da morna, símbolo da própria afirmação cultural de Cabo Verde?

Vem de Baltasar Lopes, filólogo do grupo e autor do primeiro grande tratado sobre o crioulo, a afirmação da indissociabilidade entre o povo cabo-verdiano e o falar cotidiano das ilhas: "A linguagem crioula, essa, está tão arraigada no solo das ilhas como o próprio indivíduo" (apud FERREIRA, 1985, p. 115). Assim sendo, como uma literatura que se pretendia erigir a partir de um profundo "fincar pé" no solo caboverdiano pôde ser produzida em português, e não no próprio crioulo?

Manuel Ferreira, que em mais de uma ocasião debruçou-se sobre o tema, defende a existência de um bilingüismo literário em que haja contribuições mútuas entre 
a expressão em crioulo e a expressão em língua portuguesa, ambas, afinal, pertencentes à história lingüística e literária do arquipélago.

Literariamente bilíngües já seriam, antes da Claridade, Pedro Cardoso ${ }^{6} \mathrm{e}$ Eugênio Tavares ${ }^{7}$. Contudo, há que se observar que no bilingüismo de Eugênio Tavares não ocorre qualquer interpenetração entre as duas línguas do arquipélago, pois se sua lírica em crioulo, indissociável do gênero musical cabo-verdiano por excelência, a morna, traz em si as marcas populares do falar cotidiano, de que se alimenta, sua lírica em língua portuguesa vale-se de registros lingüísticos absolutamente formais, mesmo castiços, vazados sobretudo por meio de formas fixas como o soneto.

Com o modernismo, os registros populares e eruditos de linguagem, em Cabo Verde identificados com o crioulo e o português, respectivamente, deixam de ser paralelos e interpenetram-se, o que, para Manuel Ferreira, longe de ser um problema,

\begin{abstract}
é garantia de terem eles encontrado um modo ótimo de se exprimirem _e vem a ser, em muitos casos, o compromisso entre o português e o crioulo: um português não de todo puro tal como qualquer falante de Portugal, cioso ou ortodoxo, o entenderia, mas sem dúvida contaminado pelas interferências do crioulo. (1985, p. 135)
\end{abstract}

Para Freyre, a descoberta, por parte dos africanos, de registros locais da língua portuguesa, deu-se sobretudo pela leitura de autores brasileiros que, em sua escrita, já teriam se valido desses mesmos registros. Diz ele:

\begin{abstract}
A linguagem do romancista Jorge Amado, por exemplo, ou a do romancista José Lins do Rego, ou a do romancista Érico Veríssimo, ou a do poeta Manuel Bandeira, ou a do poeta Jorge de Lima tem hoje imitadores entre jovens de Cabo Verde, da África portuguesa, do próprio Portugal. Imitadores que, nessa imitação antes ativa que servil, se utilizam de equivalentes regionais nativos das expressões portuguesas ou mestiças empregadas por vigorosos escritores brasileiros de hoje sob o impacto de condições antes regionais que nacionais de vida brasileira. (s./d., p. 116).
\end{abstract}

\footnotetext{
${ }^{6}$ Pedro Monteiro Cardoso nasceu em 1883. Poeta, jornalista e compositor, foi um dos primeiros pesquisadores da identidade cultural cabo-verdiana, tendo publicado, em 1933, o importante Folclore cabo-verdiano, em que já se debruça sobre as questões ligadas às similaridades de formação existentes entre Brasil e Cabo Verde. Faleceu em 1942.

${ }^{7}$ Eugénio de Paula Tavares nasceu na Ilha Brava, a 18 de Outubro de 1867. Órfão desde muito cedo, foi sobretudo autodidata. Jornalista, colaborou em diversos jornais e revistas, como o Almanaque de Lembranças Luso-africano, sendo um dos mais importantes animadores culturais do arquipélago entre 1890 e 1930, ano em que faleceu. Como compositor, atribui-se a ele um papel significativo na configuração da morna. Dois anos após sua morte, publicaram-se em Lisboa, aos cuidados de José Osório de Oliveira, suas Mornas: cantigas crioulas.
} 
Todos os autores brasileiros citados por Freyre tiveram seus nomes igualmente citados pelos cabo-verdianos na Claridade, sobretudo nos números iniciais, quando a busca pela afirmação literária, orientada pela experiência brasileira, liderava o rol de preocupações. Baltasar Lopes, em artigo sobre o crioulo, cita a importância de Bandeira ao chamar-lhes a atenção, em seus poemas, para a verdadeira língua do povo, transcrevendo, como exemplo, o famoso trecho de "Evocação do Recife":

A vida não me chegava pelos jornais nem pelos livros.

Vinha pela boca do povo, na língua errada do povo,

Língua certa do povo,

Porque ele é que fala gostoso o português do Brasil.

Ao passo que nós

O que fazemos

É macaquear

A sintaxe lusíada.

(apud FERREIRA, 1985, Claridade 4, p. 18)

Como resultado desse "imitar brasileiro", viu-se o aumento progressivo do espectro de literaturas em língua portuguesa produzidas a partir de contribuições de registros locais, alçados à categoria de linguagem literária devido ao trabalho de autores que, para Gilberto Freyre,

E tendem a tornar-se, todos eles _ escritores cabo-verdianos, luso-africanos, portugueses, influenciados por brasileiros _, a seu modo telúricos e regionais em sua língua e em seu estilo, escrevendo, porém, em português e não em línguas diferenciadas de tal modo da portuguesa a ponto de constituírem outras tantas línguas nacionais ou subnacionais. (s/d., p. 116)

No caso de Cabo Verde, o uso, tanto na prosa quanto na poesia, de formas do português enriquecidas pelo contato consciente com o crioulo, é mais um exemplo da significativa contribuição dos claridosos no processo de consolidação de um sistema 
literário efetivamente cabo-verdiano. Com isso abriu-se caminho para autores que, retomando o bilingüismo, produziriam textos em que conviveriam, lado a lado, o português e o crioulo, como nos poemas de Corsino Fortes, grande revelação, talvez a mais importante, da última fase da revista, já na década de 1960.

\subsection{A presença de Gilberto Freyre e o sentimento (equivocado) do Brasil}

João Lopes, no artigo "Apontamento", publicado no segundo número da Claridade, afirma que, pela falta de estudos próprios sobre a realidade cabo-verdiana, o melhor a fazer seria valer-se de estudos brasileiros, dada a similar formação afroeuropéia de ambos os países. Por "formação afro-européia", entendia Lopes, naturalmente, a mestiçagem, sobretudo segundo a partir do que fora descrito na obra mais conhecida de Freyre.

De fato, Casa Grande \& Senzala distingue-se dos trabalhos anteriores por incluir os índios, negros e mestiços como elementos decisivos para a constituição do povo brasileiro e de sua especificidade. Um enfoque, portanto, bastante distinto do de Oliveira Vianna e de outros adeptos, assumidamente ou não, das políticas oficiais de embranquecimento, enfraquecidas, é bem verdade, com a crise de 1929 e o fim da República Velha.

No entanto, seguindo preceitos das teorias funcionalistas norte-americanas, duramente criticadas por Antonio Candido em Plataforma de uma geração, Freyre procura analisar a História a partir da harmonização de opostos: o senhor e o escravo, a casa-grande e a senzala, pares que, devido à predisposição do luso para a miscigenação, aprendida ao longo de sua própria formação híbrida na península ibérica, misturaram-se sem que houvesse grandes tensões ou conflitos.

As "três raças tristes" conciliavam-se, por fim, numa relação supostamente harmoniosa, e os netos da antiga elite agrária brasileira, temerosos de qualquer associação com o passado escravocrata de seus ascendentes, abraçaram entusiasticamente a idéia, mesmo porque, se não se concebia nosso passado como uma sucessão de atos de violência e exploração, não seria preciso repartir no presente, as riquezas do país. Antes, indígenas e africanos deveriam agradecer aos portugueses pelo tratamento benigno a eles dispensado, o que não teria acontecido se tivessem caído nas mãos de terríveis ingleses ou preconceituosos holandeses. 
No conhecido artigo "Palavras sobre Cabo Verde para serem lidas no Brasil", publicado no segundo número da Claridade, José Osório de Oliveira refere-se a "novos ensaístas brasileiros" (CLARIDADE, 1936, p.4), cuja leitura, pelos cabo-verdianos, teria sido de vital importância para a consolidação do modernismo no arquipélago. Oliveira tinha em mente, sobretudo, um nome: Gilberto Freyre, citado várias vezes nesse mesmo artigo, e com quem vinha mantendo copiosa correspondência desde 1931 . A conclusão do texto destaca, como faria Freyre tantas vezes, a excelência adocicada da colonização portuguesa, o que os distinguia dos demais europeus em sua lida com os autóctones. Diz ele: “O facto positivo é a criação em Cabo Verde de um ambiente de grande liberdade humana, nascida desse processus sui generis absolutamente português, ao invés dos colonizadores anglo-saxónicos" (CLARIDADE, 1936, p.4). Anos mais tarde, partiria dele a sugestão para que o governo salazarista, na figura do Ministro de Ultramar, Sarmento Rodrigues, convidasse o sociólogo Pernambucano para uma viagem às colônias e domínios portugueses.

Curiosamente, a recepção à obra de Gilberto Freyre em Portugal e em Cabo Verde seguiu caminhos simetricamente opostos. Quando da publicação de Casa Grande \& Senzala, em 1933, o salazarismo ensaiava seus primeiros passos, apoiado pelo pensamento fascista, em franca ascensão na Europa. A elite portuguesa, católica fervorosa e pretensamente branca, viu com péssimos olhos o retrato do luso como alguém que, híbrido em sua origem, tenderia por natureza à miscigenação. Não por acaso, estudava-se em Portugal, por essa altura, a pedido do Ministro das Colônias, Armindo Monteiro (1931-1935), a introdução de políticas oficiais de segregação racial, a exemplo do que vinha sendo feito na Rodésia e na então União Sul-africana. Já os cabo-verdianos, às vésperas da publicação da Claridade, cuja principal bandeira seria justamente a especificidade crioula do arquipélago, vislumbraram em Gilberto Freyre o modelo que imaginavam ideal para a análise da realidade cabo-verdiana e rechearam a revista com citações e idéias do sociólogo.

Com o fim da Segunda Guerra Mundial e a derrocada das ideologias nazifascistas, os planos para implantação de sistemas assumidamente segregacionistas por parte da ditadura de Salazar tornaram-se inviáveis e a política lusa para a África tomou novo rumo. Não que o governo português pretendesse alterar qualquer relação mantida com suas colônias, mas o discurso acerca de tais relações, incluindo as que tiveram lugar nos séculos anteriores, deveria mudar. E o discurso luso-tropicalista, que se mostrara tão adequado aos netos dos senhores de engenho e dos barões do café, que 
emergiam como classe econômica dominante no Brasil na transição do modelo agrário para o urbano-industrial, no início dos anos de 1930, serviu como uma luva aos dedos salazaristas, afinal, não tão diferentes assim.

Do perfil que Freyre traça para os portugueses, duas características interessaram diretamente ao ideário salazarista: a natureza etnicamente democrática, visível nas relativamente boas relações entre senhores e escravos, e a capacidade civilizadora do luso nos trópicos. No trecho seguinte, o autor põe em relevo ambos os pontos:

Também quanto à relativa benignidade nas relações, no Brasil, entre os vários grupos étnico-culturais. São grupos que, interpenetrando-se, vêm concorrendo, através de considerável mobilidade social, quer horizontal, quer vertical. Para favorecer, nesta parte da América, sob a forma de uma civilização moderna em ambiente tropical, uma democracia dinamicamente étnico-cultural com o mérito pessoal tendendo, cada vez mais, a superar desvantagens tanto de etnia quanto de classe que possa prejudicar indivíduos. (1971, p. XXI)

Impossível não enxergar as idéias do brasileiro nas palavras do próprio Salazar. Em entrevista a Life, o ditador deixa transparecer em seu discurso esses dois pontos cruciais do pensamento de Gilberto Freyre: a relação harmoniosa do português com outros povos e o efeito civilizador da colonização portuguesa. Diz ele:

Estes contatos jamais envolveram a menor idéia de superioridade racial ou discriminação... creio poder dizer que a característica principal da África portuguesa - apesar dos esforços conjugados em muitos setores para atacála com palavras e ações - é a primazia que sempre demos e continuaremos a dar à intensificação do valor e da dignidade do homem, sem distinção de cor ou de credo, à luz de princípios da civilização que nós levamos às populações que em todos os sentidos estavam aquém de nós. (apud MEDEIROS, 1984, p. 35)

Não por acaso, duas das obras de Freyre em que o luso-tropicalismo é mais evidente, Integração portuguesa nos trópicos (1958) e O Luso e o Trópico (1961), foram publicadas às expensas do governo salazarista e distribuídas aos diplomatas portugueses para que as utilizassem em defesa da manutenção do colonialismo em terras africanas.

Também as críticas não tardariam. Os cabo-verdianos, que, ao contrário dos portugueses, acolheram desde o primeiro momento as idéias de Freyre, mostraram-se profundamente decepcionados com o que o sociólogo escreveu sobre Cabo Verde, 
sobretudo em Aventura e Rotina. Nesse relato de viagens, Freyre vê os habitantes das ilhas não como mestiços ou crioulos, mas como africanos que, tendo recebido certos valores europeus, encontrar-se-iam em um estado de indefinição cultural, cujos indícios seriam a fragilidade econômica, o uso de um dialeto bárbaro, incapaz de servir como meio complexo de expressão, e a ausência de uma legítima arte popular.

Baltasar Lopes, fazendo-se porta-voz do grupo da Claridade, rebate as críticas de Freyre em Cabo Verde visto por Gilberto Freyre, de 1956. Grande filólogo, talvez o principal sistematizador do crioulo cabo-verdiano, incomodou Lopes sobretudo o menosprezo pelo idioma das ilhas, que para o cabo-verdiano, sobreviveria como a verdadeira língua nacional. O tempo dar-lhe-ia razão.

As críticas mais ferrenhas, contudo, viriam, paradoxalmente, de dentro de uma instituição oficial, a Companhia dos Diamantes de Angola, na figura de seu comandante, Ernesto Vilhena. Freyre, que passara alguns dias em regiões de operação da Companhia, criticou seu modo de ação, que julgou segregacionista, por influência de um suposto modelo belga de colonização. O comandante Vilhena, que não negou o segregacionismo, defendeu-se dizendo que "A política indígena da Companhia é essencialmente a clássica e tradicional orientação portuguesa.” (1955, p. 7).

O próprio Osório de Oliveira, amigo de Freyre, e que em artigo publicado no segundo número da Claridade louvara, citando o brasileiro, a "excelência da colonização portuguesa e da nossa capacidade civilizadora" (CLARIDADE, 1936, p.4), decepcionou-se com a frivolidade das análises e com o menosprezo ao caráter crioulo de Cabo Verde.

Contudo, mesmo após a frustração da expectativa criada acerca do que Gilberto Freyre escreveria sobre Cabo Verde, levando a reações quase imediatas, como a resposta crítica dada por Baltasar Lopes com Cabo Verde Visto por Gilberto Freyre, a ideologia da miscigenação harmônica nas colônias portuguesas, sobretudo em Cabo Verde, teria seus defensores. Exemplo disso é o artigo "A originalidade humana de Cabo Verde", assinado por Pedro de Sousa Lobo e publicado no último número da Claridade, já em 1960. Sobre a dupla formação étnica cabo-verdiana, diz ele que "A fusão decorreu sem sobressaltos, nem violências, dando lugar, por uma contínua miscigenação, a um tipo humano do maior interesse antropo-sociológico." (apud FERREIRA, 1986, Claridade, nº. 9, p. 64). Seguindo a lição de Gilberto Freyre, citado textualmente, Sousa Lobo atribui a harmonia de tal miscigenação à excelência da colonização portuguesa, a qual, 
tanto em África como na Ásia, tanto na América do Sul como na Oceania, foi sempre (ou quase sempre) do tipo transculturativo da adaptação, ao contrário do que se deu com os negros, os asiáticos, os índios e os insulíndios sob o domínio de outros colonizadores. (apud FERREIRA, 1986, Claridade, $\mathrm{n}^{\circ} .9$, p. 64)

Contraditoriamente, ao referir-se a um suposto modelo transculturativo de colonização, característico dos portugueses, Sousa Lobo, faz eco ao conceito de transculturação, desenvolvido por Fernando Ortiz (1963) para descrever a formação crioula cubana, logo, sob a égide de outra metrópole colonizadora, a vizinha Espanha. Conceito que, aliás, não exclui a violência do processo de colonização.

Do artigo de Sousa Lobo depreende-se ainda a idéia de que o europeu teria sido o único agente no processo de formação cultural do arquipélago, no qual introduzira, em resposta às agruras naturais, "alguns mimos metropolitanos" (apud FERREIRA, 1986, Claridade, $\mathrm{n}^{\circ} .9$, p. 64), como vinhas e jardins temperados, raciocínio afim ao de José Evaristo d'Almeida, que em seu romance oitocentista $O$ Escravo (1856) relata os "melhoramentos" que os portugueses promoveram nas ilhas, dando-lhes, em alguns pontos, o aspecto de "uma quinta européia" (ALMEIDA, 1989, p. 25).

Quanto aos elementos de origem africana, Sousa Lobo questiona sua importância ou mesmo sua existência:

E, o que é importantíssimo quanto a nós: aquilo que a um determinado observador pode parecer África, África viva, herança africana, sobrevivência africana, comportamento africano, simples reminiscência (mais ou menos acentuadas, mais ou menos tênue) africana, sê-lo-á inquestionavelmente?

O observador estará perfeitamente cônscio da identificação?

Não lhe terá escapado qualquer pormenor importantíssimo menos visível? Nenhuma sombra terá sorrateiramente, sem que o pressinta, embaciado as suas lentes?

Relativamente a Cabo Verde, coisas que para uns são 'Ácafri', outros, igualmente autorizados (mas mais qualificados por uma longa e consciente permanência nas ilhas) identificam como 'Europa'. (apud FERREIRA, Claridade, $n^{\circ} .9$, pp. 67-68).

Citação longa que, de certo modo, pode ser resumida pela fórmula do próprio Sousa Lobo: "Cultural e sociologicamente, Cabo Verde já não é África, embora etnicamente não seja Europa." (apud FERREIRA, Claridade, nº. 9, p. 67), uma forma dissimulada de, como Antônio Vieira, afirmar que os cabo-verdianos, mesmo com o 
"acidente" $" 8$ de serem negros, gozavam, como os europeus, de admiráveis faculdades intelectuais.

Uma visão diferente da questão apareceria com Gabriel Mariano, que destaca a importância da ascensão econômica dos mulatos para sua valorização sócio-cultural em Cabo Verde, país cuja originalidade residiria na "africanização dos europeus" (MARIANO, 1991, p. 95), e não no contrário, como era comum se pensar.

Mesmo em Aventura Crioula, obra em que Manuel Ferreira busca, entre outras coisas, demonstrar que há uma cultura legitimamente cabo-verdiana, fruto de uma originalidade crioula, negada por Freyre em Aventura e Rotina, são perceptíveis vestígios da ideologia de uma miscigenação harmônica nos espaços coloniais portugueses. O "choque da conquista" (GRUZINSKI, 2001), embora não seja negado por Ferreira, perde-se na noite dos tempos, uma vez que "O homem cabo-verdiano é uma simbiose de duas culturas em trânsito para uma perfeita harmonia, para um equilíbrio cultural obtido primeiro pelo choque e depois pelo encontro das culturas em contato: africana e européia." (1985, p. 111). E, como resultado, "Cabo Verde de há muito pôde naturalmente libertar-se das implicações que relevam da natureza da epiderme..." (1985, p. 38).

\footnotetext{
${ }^{8}$ Citação exata: "São todos pretos, mas somente neste acidente se distinguem dos europeus. Têm grande juízo e habilidade, e toda a política que cabe em gente sem fé e sem riquezas, que vem a ser o que ensina a natureza." (apud FERREIRA, 1985, p. 107).
} 


\section{CAPÍtulo 3:}

\section{O Modernismo como Processo de Transição}

"A rigor, ainda que para destruir as regras ou esquecer-se delas,

é preciso _ evidentemente _ começar por conhecê-las.”

(Guillermo de Torre) 
Em seu estudo sobre a história das literaturas de vanguarda, Guillermo Torre chama nossa atenção para o fenômeno de multiplicação, no final do século XIX e começo do século XX, das tendências artísticas advindas dos movimentos de reação ao pensamento positivista. O rigorismo normativo e a inflexibilidade estética dão lugar, pouco a pouco, a uma multiplicidade de tendências (Impressionismo, Expressionismo, Cubismo, Dadaísmo, Surrealismo, Futurismo etc.) que denunciam um anseio comum por mudanças, já que os ismos "valem um único espírito novo mundial: descentralização". (1971, p. 26)

Mas se é possível, por um lado, identificar um anseio comum por mudanças, pode-se vislumbrar, por outro, uma série de diferentes percursos poéticos trilhados por cada tendência ou grupo de autores, ou mesmo, no limite, por cada autor isoladamente, no intuito de satisfazer seu desejo de renovação estética. Para Albert Thibaudet (Le Liseur de Romans), tal fenômeno estaria mesmo no cerne da definição de "geração literária", identificável nesse período de transição, já que "Aquilo que se chama uma geração literária é, talvez, simplesmente, certa maneira comum de delinear os problemas, com maneiras muito diferentes de resolvê-los." (apud TORRE, 1971, p. 55)

Tendo como objeto de estudo a poesia de Manuel Bandeira e sua importância para a consolidação da literatura cabo-verdiana, tratamos de averiguar o que há de similaridade no modo como o autor de Libertinagem e os autores da Claridade buscaram resolver, diferentemente de outros, a questão que a todos, então, igualmente se impunha: a construção de literaturas modernistas em seus respectivos países.

Destacaremos, no presente capítulo, três pontos de convergência que unem Bandeira e os claridosos em seus percursos poéticos: primeiramente, a matriz simbolista comum, que se depura progressivamente, sobretudo pela dissolução das estruturas rítmicas, no Brasil, pelos poetas penumbristas, dentre os quais o Bandeira dos primeiros livros, e, em Cabo Verde, pelos poetas da fase "hesperitana", às vésperas do surgimento da Claridade; em seguida, o modo de se relacionarem com a herança do passado, sobretudo acerca da tradição lírica portuguesa; e, finalmente, no que diz respeito à fatura textual, a descoberta de formas próprias, capazes de expressar temas nacionais que, mesmo não sendo inéditos, só se versavam por meio de modelos europeus. 


\subsection{Simbolismo - Penumbrismo - Modernismo: caminhos da transição}

O Simbolismo, já em si uma reação à ordem literária estabelecida pelas correntes positivistas, perduraria (assimilado, mais do que diluído), em muitos aspectos, entre os movimentos de vanguarda do início do século $\mathrm{XX}$, fornecendo-lhes subsídios

estéticos para as transformações pretendidas. É o que constata Fernando Góes, em momentos diversos, seja fazendo referência à reação simbolista, "Porque, antes de mais nada, o simbolismo foi, como todas as escolas literárias que se prezam, um movimento de revolta contra as formas consagradas da arte." (1959, p.3), seja aludindo à conseqüente transformação estética, já que "Do ponto de vista da forma e da arte poética, fizeram os simbolistas brasileiros uma verdadeira revolução.” (1959, p.13).

Também Norma Goldstein, na obra em que analisa a poesia penumbrista brasileira, deixa evidente esta mesma idéia já a partir do título de sua introdução: "O Simbolismo como ponto de partida para o estudo da poesia modernista: o veio crepuscular”. E, adiante, ainda na mesma introdução, após enunciar certas divergências teóricas acerca do movimento, conclui: "Há, no entanto, um ponto em que todos os autores são unânimes: o Simbolismo é considerado manancial para as tendências poéticas do Modernismo.” (1983, p. 3)

Se é pertinente dizer com propriedade que o Simbolismo serviu de estofo para os poetas modernistas brasileiros em geral, o mesmo, e com mais razão, aplica-se a Bandeira especificamente. $\mathrm{O}$ inventário de nomes que o próprio poeta expõe em Itinerário de Pasárgada como fontes decisivas para sua formação não deixa a menor dúvida. Entre Simbolistas propriamente ditos e poetas crepusculares, cita os franceses Verlaine, Samain, Guérin, Verhaeren e Francis Jammes, os italianos Palazzeschi, Soffici, Goroni e Corazzini, além do português António Nobre, que julga, aliás, representar a última grande influência da poesia portuguesa sobre o Brasil.

Na depuração de sua linguagem rumo a uma estética francamente modernista, nota-se, de fato, um abandono progressivo do rigorismo formal parnasiano, processo gradual já perceptível em O Ritmo Dissoluto, de 1919, e cujo ápice seria atingido em Libertinagem, de 1930. No entanto, elementos estéticos herdados do Simbolismo, como a presença recorrente da musicalidade, serão uma constante em todos os seus livros.

Anna Balakian, em um dos mais importantes estudos sobre o Simbolismo, destaca, dentro das diversas tendências que o compuseram, três traços comuns que lhe serviriam de amálgama: “A ambigüidade da comunicação indireta, a associação com a 
música e o espírito 'decadente'." (1985, p. 81) Em graus e modos diferentes, esses três aspectos definidores do Simbolismo são observáveis na poesia de Manuel Bandeira, não apenas em seu período penumbrista (A Cinza das Horas e alguns poemas de Carnaval), mas em sua obra modernista, e na poesia cabo-verdiana, tanto às vésperas da publicação da revista Claridade, quanto nos versos que revestem suas páginas.

A "ambigüidade da comunicação indireta", fruto da reação ao preciosismo descritivista do Naturalismo/Parnasianismo, é uma constante na obra e no pensamento de Mallarmé, para quem a poesia é "a anunciação de imagens suspensas, oscilantes, e constantemente evanescentes" (HAUSER, 1968, p. 1078), afinal, "nomear um objeto é destruir três quartos do prazer que reside no adivinhar gradual da sua verdadeira natureza." (apud HAUSER, 1982, p. 1078); e traduz-se, em Verlaine, pela defesa da sugestão e da imprecisão de sentimentos, já que "as emoções agridoces são mais sutis do que as apenas doces ou amargas." (apud BALAKIAN, 1985, p. 53). "Emoções agridoces" que Goldstein observa nos penumbristas brasileiros como "melancolia agridoce" (1983, p. 5) e Hamilton, em Cabo Verde, como "sentimento agridoce discernível em muitas obras cabo-verdianas" (1984, p. 127).

Balakian observa ainda, nesse momento do Simbolismo, em seu principal núcleo de difusão, a França, a presença de autores de outros países, que cuidarão de emprestar ao movimento as cores de suas específicas nacionalidades. Diz ela:

O segundo influxo de escritores estrangeiros para a França é diferente do primeiro; os últimos chegam não para tentar se tornar simbolistas franceses, como fizeram os anteriores, mas para adaptar o Simbolismo ao seu caráter nacional e às suas tradições literárias. (1985, p. 83)

Conforme se vê em crônicas ou no Itinerário de Pasárgada, muitos dos autores citados por Balakian como representantes desse "segundo influxo", como António Machado e Miguel de Unamuno9, estiveram entre os preferidos de Bandeira. Ruben Darío, nicaragüense que aportou em Paris em 1892 e cujos escritos orientariam grande parte da renovação poética nos países hispano-americanos, encontrou no poeta brasileiro não apenas um exímio tradutor, mas um divulgador entusiasta de sua obra.

Dentre os brasileiros que testemunharam esse ambiente de abertura do Simbolismo às tradições literárias nacionais, merece destaque a figura de Nestor Vítor,

\footnotetext{
${ }^{9}$ Ver BANDEIRA, 1958, pp. 520 e 686.
} 
o mais importante crítico do Simbolismo brasileiro, ele próprio um poeta significativo do movimento, que viveu em Paris por quatro anos, de 1902 a 1905, trabalhando como correspondente dos jornais Correio Paulistano e $O$ País, este, muito lido por Bandeira em sua juventude. Amigo íntimo de Cruz e Sousa, de quem editaria os últimos trabalhos, Vítor escreveu diversos artigos sobre a cultura e a literatura francesa, franqueando aos que aqui estavam o que então se produzia de novo na Europa.

$\mathrm{Na}$ década seguinte, o próprio Bandeira encontrar-se-ia na Europa, para tratamento de sua doença, não em Paris, é verdade, mas no sanatório de Clavadel, na Suíça, onde partilha suas horas com Paul Éluard, que se tornaria, segundo o próprio Bandeira, um dos maiores nomes da literatura francesa no século XX. Datam desse período os poemas que compõem A Cinza das Horas (1917), considerado por Nestor Vítor (1923) uma obra de transição. João Ribeiro, que também ocupou-se da obra de estréia de Bandeira, classificou-a como "A poesia nova", título de um artigo publicado no jornal O Imparcial, parcialmente transcrito em Itinerário de Pasárgada. Diz Ribeiro:

\footnotetext{
A Cinza das Horas, pequenino volume, é neste momento um grande livro. De tal arte nos havíamos estragado o gosto com o abuso das convenções, dos artifícios e das nigromâncias mais esdrúxulas, que esta volta à simplicidade e ao natural é uma consolação reparadora e saudável. (apud BANDEIRA, 1977, p. 56)
}

Ao destacar o despojamento de artificialismos e a busca por uma maior naturalidade da expressão, Ribeiro soube observar, desde o primeiro momento, uma das características essenciais da lírica de Bandeira, que se intensificaria nos livros seguintes e que permitia, por essa altura, incluí-lo entre os penumbristas, que, em surdina, vinham aproximando a literatura dos registros populares de cultura.

Mas essa aproximação exigiria, naturalmente, um esforço por mudanças formais. Urgia, sobretudo, minorizar o desgastado hermetismo da linguagem, levado ao extremo pela repulsa ao naturalismo e sua maneira supostamente crua, não-mediata de representação da realidade. A solução, para Balakian, viria também de forma gradual, já que nesse período final do Simbolismo, "A forma mais bem-sucedida de símbolo foi a criada pela fusão da realidade física ou concreta com o estado de espírito interior ou abstrato." (1985, p. 87)

Em nosso entender, essa mescla de realidade física e interioridade abstrata, já em si uma reação ao rigorismo dogmático parnasiano, assinala o caráter de transição desse 
período, no qual se processou a incorporação progressiva de elementos inovadores, associados, sobretudo, à flexibilização rítmica.

Para Bosi, as marcas desse processo podem ser detectadas em quase todos os autores modernistas, embora sejam mais nitidamente visíveis nos que se iniciaram nas letras antes da consolidação do Modernismo. Diz ele:

\footnotetext{
Em outros escritores que começaram a sua carreira antes de 22, é ainda mais visível a impregnação de um passado recente. Manuel Bandeira e Ribeiro Couto foram intimistas da última fase do Simbolismo. Bandeira, com $A$ Cinza das Horas, parecia um eco perdido do Decadentismo belga ("Eu faço versos como quem morre"), mas já assimilaria, em Carnaval (1919), sugestões mais ousadas dos crepusculares italianos Corazzini e Gozzano, poetas capazes de dissolver em auto-ironias cadências heróicas de Caducci e D’Annunzio. (1994, p. 334)
}

Também em Cabo Verde, dos primeiros anos do século XX à década de 1930, quando surge a Claridade, um processo semelhante de transformações literárias progressivas pode ser observado. Em José Lopes, Pedro Cardoso e Eugênio Tavares, representantes da "geração da ambigüidade" (FERREIRA, 1986, p. XLV), é perceptível um sentimento ainda incipiente de nativismo, expresso, como não poderia deixar de ser, em formas regulares européias. António Pedro, pouco depois, arrisca os primeiros poemas polimétricos em seu Diário (1929), um precursor, sem dúvida, para os versos livres de Claridade. Pires Laranjeira (1995) chama nossa atenção para o prolongamento, por parte de Eugênio Tavares e de suas mornas, de uma atmosfera fim-de-século, que se estenderia sobre Claridade e suas ramificações futuras. Para Ana Luísa Ventura Pereira (1995), por exemplo, o próprio sentimento de instabilidade decorrente da condição insular, quer para os claridosos, quer para vários autores açorianos, seria já um ponto de afinidade, dada sua semelhança com certos núcleos temáticos do Simbolismo (imagens marítimas, dolência, imprecisão de sentimentos.

\subsection{Entre necessária e maldita, a herança do passado}

A multiplicidade de tendências do Modernismo a que acima nos referimos não passou despercebida por autores e críticos brasileiros, muitos dos quais se posicionaram a respeito da questão. Para o gaúcho Raul Bopp (1966, p. 36), poeta e pensador 
múltiplo, que freqüentou grupos os mais diversos após a Semana de 22, do Verdamarelismo à Antropofagia, haveria um Modernismo de "evolução", praticado, por exemplo, no Rio de Janeiro, desde a revista Fon-fon!, e um Modernismo de "revolução", que emerge a partir do grupo paulista. Wilson Martins, levantando uma hipótese, expressa-se sobre a questão de modo muito semelhante, valendo-se, inclusive, dos mesmos termos, pois, para ele “... talvez, sem a 'Semana', não tivéssemos uma 'revolução', mas uma 'evolução' natural dessa linha, em direção ao Modernismo." (1967, p. 224). Para Alfredo Bosi (1994, pp. 335-336), são discerníveis, nesse momento, duas correntes principais: uma "impressionista-cubista-abstracionista", cujas preocupações estariam centradas na "construção do objeto poético autônomo", e outra "primitivista-expressionista-surrealista", à qual se filiaria Bandeira e sua poética de alumbramentos.

A forma imprecisa de se nomear tais tendências, pela simples justaposição de adjetivos, já denuncia a dificuldade de se conceituar um movimento essencialmente múltiplo como o Modernismo. Como quer que seja, as diversas tendências acabam por configurar, em certa medida, dois modos distintos de ação diante da tarefa (nada fácil) de promover a transformação almejada para as formas literárias. Um primeiro que, mesmo tendo produzido obras "viciadas pelo decadentismo retórico" (BOSI, 1994, p. 334) em seu período de formação (Os Condenados, de Oswald de Andrade, Moisés e Máscaras, de Menotti del Picchia), prega a ruptura incondicional com o passado, aderindo, não exatamente ao Futurismo enquanto escola ou doutrina literária, mas a uma idéia futurista que busca associar o modernismo literário a um modelo urbano de modernidade. E outro que, tendo como objetivo comum a emancipação das formas literárias, busca fazê-lo progressivamente, dando continuidade a um processo que se iniciara, ainda que discretamente, com o Simbolismo, e que ganhara força entre os poetas penumbristas.

Naturalmente, aos diferentes meios empregados na busca pela transformação literária corresponderiam formas igualmente distintas de se relacionar com a herança cultural e literária do passado, sobretudo no que diz respeito à herança portuguesa.

Mário de Andrade, tomando como genérico seu próprio modo de ação, mais um dentre tantos outros existentes, diz que o modernismo "Foi uma ruptura, foi um abandono de princípios e técnicas conseqüentes, foi uma revolta contra o que era a Inteligência nacional.” (1942, p. 25), opinião também de Mário da Silva Brito, para quem "Um dos traços marcantes do modernismo é apartar das letras a influência 
portuguesa, é a ruptura com as formas tradicionais e de expressão, fundadas no purismo, na gramática herdada dos descobridores." (1997, p. 136) A nosso ver, ambos incorrem em erro ao atribuir a todo o Modernismo uma característica pertinente a um grupo que, conquanto fosse talvez o mais representativo, não pode ser considerado único.

Longe de pertencer somente à esfera das discussões literárias, o sentimento antiluso, perceptível nas obras de Mário e Oswald de Andrade, vinha ganhando corpo com a aproximação das comemorações do primeiro centenário da Independência política do Brasil. Associações entre patrióticas e patrioteiras, como a Ação Social Nacionalista (1915), cresciam em poder econômico e número de adeptos, leitores ávidos da revista Brazílea (1917) e de Bilac, já alçado, por essa altura, à condição de "poeta cívico" (BOSI, 1994, p. 226), dividindo-se entre a luta (nem sempre vã) com palavras e a defesa apaixonada do serviço militar obrigatório.

A “onda lusófoba” (SARAIVA, 2004, p. 74), perceptível em textos de nacionalistas de direita, como Jackson de Figueiredo, co-autor, com Bilac, de obras didáticas, atingiu, por vezes, tons inflamados, como em As razões da Inconfidência (1925), de Antônio Torres, com a defesa de um enfrentamento mais aberto aos persistentes vínculos com Portugal. Para Figueiredo: “O Brasil libertou-se do governo português; continua contudo a suportar agora sem mais impaciência a ascendência dos lusitanos no seu comércio, indústria, imprensa e até nas letras.” (1921, p. 50)

Em carta a Carlos Drummond de Andrade, que escrevera, pouco antes, serem os portugueses um "povo que gerou os Lusíadas e morreu"10, Mário de Andrade chegou a classificar Portugal como "um paisinho desimportante" (1982, p. 22) para os modernistas, opinião compartilhada por Tristão de Ataíde, para quem "Portugal deixou, de tudo em tudo, de exercer sobre nós qualquer espécie de influência literária” (1928).

Deve-se observar, contudo, que, ao menos da parte de Mário de Andrade, a declaração de repúdio à herança portuguesa parecia fazer parte de uma estratégia emancipadora, segundo a qual seria profícuo manifestar a pouca importância de Portugal para a moderna literatura brasileira, ainda que isso não se verificasse na prática. É o que o próprio autor declara em carta a José Osório de Oliveira: “A verdade é que nas minhas tentativas de dar a minha contribuição pessoal à realidade brasileira, me esqueço propositadamente de Portugal (...)” (apud SARAIVA, 2004, p. 389)

10 "Poesia Brasileira”, in: Diário de Minas, 17/10/1924. 
Desejo semelhante de distanciamento é dispensado, por essa vertente, à própria herança brasileira. No artigo "Matemos Peri!" ${ }^{11}$, publicado na edição paulista do Jornal do Commercio, Menotti del Picchia engrossa, a partir da crítica à artificialidade dos símbolos nacionalistas românticos, o tom de repúdio ao passado. Mesmo a arte colonial brasileira, cuja natureza mestiça seria revalorizada anos mais tarde, é incluída entre os exemplos de passadismo a se combater em nome de um país moderno e urbano que emergia com o processo de industrialização.

Dentro da crítica literária, merece destaque uma série de artigos publicados por Mário de Andrade também na edição paulista do Jornal do Commercio. Ironicamente intitulados "Mestres do Passado", 12 , Mário faz um balanço negativo dos principais poetas parnasianos, possuidores então de enorme prestígio público, criticando de Francisca Júlia (“a de menos inspiração”) e Raimundo Correia (“a sua inspiração era muito curta e rara") a Alberto de Oliveira ("perseguido por uma grande infelicidade: não teve que dizer") e Olavo Bilac (“não o considero dos maiores”).

Outra vertente de extrema importância para a constituição de nosso Modernismo buscou relacionar-se de modo completamente diverso diante da herança do passado, viesse ela da própria literatura brasileira anterior ao Modernismo ou da tradição lírica portuguesa. Para os autores desse grupo, a emancipação literária, por eles igualmente desejada, não deveria impedir o pertencimento a uma tradição lírica que, nascida com os cancioneiros medievais, não teria outra pátria senão a própria língua. Inscrevem-se em suas fileiras poetas como Guilherme de Almeida (Meu Portugal, 1933), Ribeiro Couto (Sentimento Lusitano, 1961) e, evidentemente, Manuel Bandeira, a quem o crítico português Arnaldo Saraiva atribuiu um "jeito de Portugal" (SARAIVA, 2004, p. 203) e cujo livro de estréia, A Cinza das Horas (1917), faz referência direta a autores portugueses nos sonetos "A Camões" e "A Antônio Nobre" e a temas trovadorescos no "Solau do Desamado".

O próprio Bandeira destaca, ao comentar as primeiras impressões causadas por sua estréia, uma observação de Américo Facó, para quem A Cinza das Horas seria uma obra de "raízes portuguesas",13, imagem que, estendida à poesia de Bandeira em geral, seria utilizada anos depois por Henrique Galvão na introdução à edição portuguesa dos poemas do brasileiro, o "mais alto valor contemporâneo de uma poética luso-brasileira

\footnotetext{
11 Jornal do Commercio, SP, 23/1/1921.

12 Transcritos em BRITO, 1997: pp. 251 e ss.

${ }^{13}$ Fon-fon!, 28/4/1917, apud BANDEIRA,
} 
(muito portuguesa nas raízes, muito brasileira nos ramos).” (apud BANDEIRA, 1956b, p. 1). Raízes que mergulham em fontes profundas do idioma, mesmo quando o intento é promover mudanças. Em carta datada de 1925, antes, portanto, das inovações radicais de Libertinagem (1930), já dizia o poeta: "No português que falo e escrevo hoje, mesmo quando me utilizo de formas brasileiras mais rebeldes à tradição clássica, eu sinto as raízes profundas que vão mergulhar nos cancioneiros.” (apud SARAIVA, 2004, pp. 212-213). Imagem que, longe de adequar-se apenas à obra inicial de Bandeira, mostrase vivaz para toda sua trajetória poética, pois "Apesar de ter sido ele quem, pela primeira vez entre nós, empregou o verdadeiro verso livre, não se tornou necessário o abandono das cadências tradicionais para que nos desse algumas das suas criações mais audaciosas" (HOLANDA, 1978, p. 13), fenômeno natural em uma obra surgida, "não obstante os influxos simbolistas, após um contato assíduo com a venerável tradição lírica de Portugal.” (Idem)

Também em seus trabalhos de crítica literária, as relações de Bandeira com os "mestres do passado", sem ironia, mostraram-se bastante distintas. Tendo iniciado sua produção poética como um "intimista da última fase do Simbolismo" (BOSI, 1994, p. 334), o poeta pernambucano nunca negou a importância das estéticas parnasiana e simbolista (de que se considerava tributário) em sua formação, motivo pelo qual declarou não se sentir à vontade para participar da Semana de 22. Raimundo Correia, tão criticado por Mário, era para Bandeira autor de "alguns dos versos mais misteriosamente belos da nossa língua” (1961, p. 12). Bilac, mesmo tendo sua "Profissão de Fé" parodiada por Bandeira em "Os Sapos", fazia-o "sentir nos grandes escritores do passado esse elemento indefinível que é o gênio da língua, a que sempre se mostrou tão particularmente sensível. A sua lição foi, e continuou sendo vida afora, muito preciosa para minha experiência poética.” (BANDEIRA, 1977, p. 36).

Longe de representar apenas uma tomada de posição, a relação de Bandeira com a herança portuguesa ou brasileira anterior ao Modernismo implicou um modelo de transformação gradual da literatura, sem cortes abruptos e com o suporte, em grande medida, das próprias lições aprendidas a partir do convívio com autores do passado e do estudo de suas obras. O que, de modo muito semelhante, ocorreria com os claridosos em Cabo Verde. 


\subsection{Da meia-luz à Claridade: a transição cabo-verdiana para o modernismo}

Em Cabo Verde, pode-se observar um processo semelhante ao brasileiro de transfiguração poética, partindo-se de uma poesia de natureza decadentista, que se estende pelas primeiras décadas do século vinte, até que se atinja a liberação formal de que dão testemunho os poemas publicados em Claridade. A revista, vinda à luz em 1936, foi, como se sabe, o órgão literário responsável pela introdução do Modernismo no arquipélago, buscando promover uma emancipação formal com relação aos modelos portugueses. No entanto, por se tratar, de certa forma, de um momento de transição, são perceptíveis nos poemas, ensaios e textos de ficção da revista vestígios da literatura anterior, ainda fortemente vinculada, histórica e esteticamente, ao sistema português, trazendo em si "A contaminação do velho pelo novo e a emergência do novo a partir do velho.” (FERREIRA, 1975, p. LXXIX). Dessa interpenetração nasceria, para Jaime de Figueiredo, a característica convivência, na literatura cabo-verdiana, de poesia "de sentido moderno" e "formas residuais de ultrapassada influência humanista." (1961, p. XII).

No período que antecede imediatamente a Claridade, alguns autores portugueses, de passagem ou mesmo morando no arquipélago, ocuparam lugar de destaque no cenário ainda restrito das letras cabo-verdianas. Alguns, como o capitão antifascista Augusto Casimiro e José Osório de Oliveira, que publicou as Mornas: Cantigas crioulas, de Eugênio Tavares, em Portugal, contribuíram para a consolidação de um ambiente literário propício à emancipação dos autores cabo-verdianos a partir de meados da década de 1930. Tais autores cuidaram, além disso, de uma divulgação efetiva de revistas portuguesas que vinham divulgando idéias e preceitos estéticos modernistas em terras lusas.

Aos portugueses, somam-se autores de extrema importância, que, embora nascidos em Cabo Verde, prendem-se ainda diretamente ao sistema literário português, numa espécie de indefinição identitária que levou Manuel Ferreira a classificá-los como a "geração da ambigüidade" (1986, p. XLV). São eles José Lopes, Pedro Cardoso, Eugênio Tavares, cultuado como um verdadeiro herói nacional cabo-verdiano em função de suas mornas, e António Pedro.

Tal indefinição identitária tornava quase impossível um entendimento do arquipélago cabo-verdiano como algo que não fosse uma mera extensão do território 
português, impedindo qualquer tentativa de se pensar em uma literatura distinta, inserida em um sistema próprio, não europeu.

Em José Lopes e Pedro Cardoso, tal indefinição quanto à origem e, portanto, quanto à própria identidade, se portuguesa, se cabo-verdiana, assume um caráter mítico a partir de comparações feitas por ambos entre Cabo Verde e grupos de ilhas lendárias, como as Hespérides. Nas Hesperitanas (1929), de Lopes, a indefinição de espaço alarga-se para abarcar também o Brasil, como se depreende dos versos seguintes:

$$
\begin{aligned}
& \text { gravados na minh'alma que assim sente, } \\
& \text { três nomes ficarão eternamente: }
\end{aligned}
$$$$
\text { Cabo Verde, Brasil e Portugal. }
$$

(apud FERREIRA, 1986, p. XXXVII)

Já Pedro Cardoso, às vésperas do surgimento da Claridade, no prefácio de seu Sonetos e Redondilhas, de 1934, mostra-se bastante veemente ao considerar Cabo Verde um pedaço de Portugal: "Sim, seja entendido, de uma vez para todo o sempre, que Cabo Verde é tão Portugal como o Minho ou a Madeira." (apud FERREIRA, 1986, p. LXX). Mesmo no prefácio que escreveu para a coletânea Mornas: cantigas crioulas, de Eugênio Tavares, obra tida como fundamental para a consolidação da identidade caboverdiana, logrou afirmar que "Cabo Verde é uma terra portuguesa. Um bloco ideal do velho heroísmo lusitano..." (Idem).

A própria crítica diverge sobre a classificação de tais autores. Para Hamilton, Eugênio Tavares é um "precursor" (1984, p. 111), já que consolida com sua lírica uma temática nativista que serviria, anos mais tarde, de alicerce à Claridade. Manuel Ferreira, por sua vez, por privilegiar a forma, e não os temas, reserva tal classificação apenas para António Pedro, que com os versos polimétricos de seu Diário (1929), causou certamente profunda impressão no jovem Jorge Barbosa que então começava a produzir seus primeiros poemas. Em um meio em que ainda imperavam os temas advindos de uma atmosfera fim-de-século, em geral construídos a partir de modelos já superados na Europa, empurrados, pouco a pouco, para as margens do sistema colonial, a opção por temas ligados à realidade das ilhas, em versos de métrica irregular e sem a obrigatoriedade das rimas, contribuíram para a consolidação de um ambiente literário propício ao surgimento da revista Claridade. 
Pedro, natural da ilha de Santiago, de onde saiu, ainda muito novo, para viver em Portugal, retornou ao arquipélago aos 19 anos (1929), trazendo consigo uma bagagem de vanguarda logo partilhada com Jaime de Figueiredo e Jorge Barbosa. Já no ano de sua volta, publicou na cidade da Praia o livro Diário, surpreendente pela inclusão da paisagem e dos dramas locais como temas e pelo uso desinibido de versos polimétricos. Não por acaso, foi o único autor anterior à Claridade incluído em No Reino de Caliban (1975), conhecida antologia organizada por Manuel Ferreira, que se refere a ele nos seguintes termos:

\begin{abstract}
Numa época em que, para os literatos cabo-verdianos, a realidade social e humana crioula literariamente não cabia na sua perspectiva, Diário, que António Pedro ali mesmo edita (cidade da Praia), forçosamente haveria de os impressionar e ajudá-los. Sobretudo a Jorge Barbosa, e não só na descoberta da modernidade formal do verso mas também no abandono espetacular de uma matéria poética de fatal subserviência perante o que, nesse domínio, de mais gasto havia em Portugal. Não era que a poesia de Diário se tecesse de um conteúdo de autêntica cabo-verdianidade mas, embora carecendo de rigor e profundidade humana, continha a novidade de quem, um pouco displicentemente, é certo, tenta olhar à sua volta. E isto, só por si, na poesia de Cabo Verde em língua portuguesa, era então um fenômeno inédito e porventura sedutor. (1975, p. 74)
\end{abstract}

Exatamente por essa altura, os cabo-verdianos tomam conhecimento da nova poesia que vinha sendo praticada no Brasil, sobretudo por intermédio de José Osório de Oliveira, amigo de Ribeiro Couto e divulgador, no arquipélago, da literatura modernista brasileira. A antologia por ele organizada, Literatura Brasileira, de 1926, é a primeira, das publicadas em Portugal, a compor-se exclusivamente de autores de vanguarda, o que causaria significativo impacto, a ser superado apenas pelas publicações, quatro anos mais tarde, de Libertinagem, de Manuel Bandeira, e de Alguma Poesia, de Carlos Drummond de Andrade. Osório, entusiasta da literatura cabo-verdiana, buscou também estreitar os vínculos entre Mário de Andrade, com quem trocou farta correspondência de 1923 a $1943^{14}$, com permuta de livros e revistas, e os claridosos. Em carta a Manuel Lopes, o português sugere o envio da Claridade a Mário, o que possivelmente ocorreu, já que há exemplares dos três primeiros números da revista na coleção Mário de Andrade do IEB/USP, composta pelo espólio pessoal do escritor paulista.

Pela primeira vez na literatura cabo-verdiana (e uma das primeiras no universo das literaturas africanas em língua européia), pode-se observar uma busca consciente 
por modelos literários produzidos por um país não hegemônico, e em cuja história estiveram presentes dramas semelhantes, como a colonização e o escravismo.

Se foi amplo o espectro de autores brasileiros cujos versos, pelas mãos de Osório, desembarcaram em Cabo Verde às vésperas da publicação da Claridade, diferente foi a recepção de cada um deles no arquipélago e, conseqüentemente, sua importância para a constituição do Modernismo cabo-verdiano.

Jorge de Lima, que iniciou sua carreira literária como um sério produtor de versos alexandrinos, chegando a ser laureado com o título de "príncipe dos poetas de Alagoas", causou espécie entre os cabo-verdianos com sua poética afro-brasileira, nascida de seu contato com o Centro Regionalista do Nordeste, fundado por Gilberto Freyre em 1924 e de que faziam parte, dentre outros, José Lins do Rego e José Américo de Almeida.

As referências a Drummond, sobretudo após a publicação de A Rosa do Povo (1945), pertencem ao segundo momento da Claridade, a partir de meados da década de 1940, quando as vozes de ambos os lados do Atlântico, em resposta à experiência dolorosa da Segunda Guerra Mundial, afinam-se pelo mesmo diapasão da poesia social.

Mário e Oswald de Andrade, figuras centrais na Semana de 22, não parecem ter despertado grande interesse, não havendo referências diretas a eles na Claridade, o que se verifica também nas longas entrevistas concedidas por autores cabo-verdianos, incluindo-se Baltasar e Manuel Lopes, a Michel Laban (1992).

Percebe-se, por outro lado, uma grande afinidade dos claridosos com Manuel Bandeira e Ribeiro Couto, cujas poéticas firmaram-se por um processo gradual de depuração estilística, que, se lança ramos, não deixa de ter entre suas raízes a própria tradição lírica portuguesa.

Ora, se para os brasileiros, cem anos após a independência política, ainda era polêmica a questão de haver ou não uma literatura nacional realmente distinta da portuguesa, como atestam as referências feitas à Semana de 22 como um "Grito do Ipiranga literário", o que dizer de Cabo Verde, ainda imerso no colonialismo, em um ambiente difuso em que nem mesmo os autores que se dedicavam a temas nativistas sabiam se diferenciar com clareza dos portugueses?

Neste cenário ambíguo, de indefinição identitária e domínio colonial, seria impensável em Cabo Verde, como se verificou no Brasil, uma onda antilusa, e, por

\footnotetext{
${ }^{14}$ Ver transcrição da correspondência em SARAIVA, 2004, pp. 382-461.
} 
extensão, uma literatura que se proclamasse revolucionária a ponto de prescindir de quaisquer vínculos com a literatura da metrópole. ${ }^{15}$

Mesmo a publicação da Claridade não logrou resolver definitivamente a questão de haver ou não uma identidade literária cabo-verdiana perfeitamente distinta da portuguesa. Embora as associações míticas anteriores já não fossem tão freqüentes e a busca de uma identidade legitimamente cabo-verdiana estivesse entre os objetivos do grupo claridoso, ainda não se tem uma percepção nítida da revista como órgão de um movimento não-português. Um ano após a publicação do primeiro número, viria à luz na Presença, revista portuguesa em que colaboraram vários cabo-verdianos, o seguinte comentário sobre a Claridade:

É a primeira manifestação de autêntico espírito moderno português fora da metrópole. Note-se ainda o caráter nitidamente cabo-verdiano desta publicação, em que um particularismo indiscutível, uma personalidade própria, sabe integrar-se no universal sem perder as suas características. (apud FERREIRA, 1986, XXVI; grifo nosso)

Exemplo significativo da ambigüidade identitária do período pode ser dado pelo livro de testemunho Memórias e reflexões (1947), de Juvenal Cabral, ninguém menos que o pai de Amílcar Cabral, herói dos movimentos de independência da Guiné-Bissau e de Cabo Verde. Juvenal, um dos raros negros a receber educação formal em Cabo Verde nas primeiras décadas do século XX, enaltece em suas memórias a educação portuguesa recebida, que o teria livrado das influências bárbaras das selvagens matrizes africanas. A língua crioula, uma das principais bandeiras dos claridosos, é definida como "restos fragmentados de um português arcaico deturpado", lembrando o Gilberto Freyre de Aventura e Rotina, em quem o crioulo causaria repugnância, ao contrário do português falado em Cabo Verde, "sempre com açúcar" (s./d. b, p. 240), como no Brasil.

A idéia de que a Claridade seria de fato um movimento de ruptura brusca com a literatura portuguesa surgiria muito mais tarde, com o movimento de independência, quando, por razões óbvias, buscou-se construir um histórico de ruptura de Cabo Verde

\footnotetext{
${ }^{15}$ Embora Pedro Cardoso, em seu Folclore Cabo-verdiano (1933), faça comentários elogiosos a autores da Inconfidência Mineira, símbolo da aversão a Portugal (ver o já mencionado As razões da Inconfidência, de 1925, do brasileiro António Torres), e que teriam deixado, segundo a tradição, descendentes em Cabo Verde. Com a independência brasileira, houve também quem sugerisse o desligamento de Cabo Verde da metrópole, passando a constituir uma província brasileira. A esse respeito, ver OLIVEIRA, 1998, p.30.
} 
com a metrópole. É o que se pode ver em textos teóricos de Amílcar Cabral, como em sua conferência "Apontamentos sobre poesia Cabo-Verdiana", em que, confrontando a Claridade com os autores que a precederam, eivados do classicismo europeizante aprendido no Liceu, afirma:

\begin{abstract}
Bruscamente, porém, opera-se a transformação. A poesia cabo-verdiana abre os olhos, descobre-se a si própria, _ e é o romper duma nova aurora. É a claridade que surge, dando forma às coisas reais, apontando o mar, as rochas escalvadas, o povo a debater-se nas crises, a luta do cabo-verdiano 'anônimo', enfim, a terra e o povo de Cabo Verde. (1978, p. 27)
\end{abstract}

Contudo, o próprio Cabral, ao refletir sobre as mudanças que possibilitaram o surgimento da Claridade, entende o processo como um fenômeno lento de busca de uma identidade cabo-verdiana, desencadeado por uma intelectualidade que,

(...) passando de São Nicolau para a cidade do Mindelo, à beira do Porto Grande, encontrou-se em contato mais amplo com o Mundo, onde se operava, dia a dia, a evolução da mentalidade humana, concretizando-se as aspirações do homem. (1978, p. 28; grifo nosso)

Deve-se destacar o fato de que, a meio caminho entre a ideologia da defesa da educação européia, feita por Juvenal Cabral, e a postura revolucionária de seu filho, Amílcar Cabral, encontra-se exatamente o grupo da Claridade, cujo trabalho progressivo, se não abriu, tornou mais suaves os caminhos que levariam à independência cultural e mesmo política de Cabo Verde.

\title{
3.4 A busca pela "unidade de imaginação"
}

Para Gaston Bachelard (1998), a atividade mental humana constitui-se de duas espécies de "forças imaginantes"; uma, denominada "imaginação material", teria como objetivo a descoberta de princípios essenciais autônomos; a outra, denominada “imaginação formal”, conferiria às essências descobertas pela imaginação material uma realidade apreensível, pertencendo, pois, ao universo da linguagem. A tarefa de encontrar a forma adequada para a expressão de cada conteúdo essencial, designada por 
Bachelard como "unidade de imaginação", caberia aos poetas (ou aos artistas, de um modo geral).

Estabelecendo-se um paralelo entre o pensamento de Bachelard e a lingüística saussureana (1969, pp. 80-81), pode-se comparar a langue, isto é, o repertório abstrato de possibilidades de cada língua, e a parole, realização material dessas mesmas possibilidades, às formas de imaginação, material e formal, respectivamente. É possível, ainda, estender o mesmo raciocínio à esfera do signo lingüístico, constituído para o lingüista suíço de "significado" ("conceito"), comparável à imaginação material, e "significante" ("imagem acústica"), comparável à imaginação formal.

Algo semelhante é definido por Hall como tarefa do "intelectual orgânico" (2003, p. 323), apto a promover, nos processos de constituição das novas nacionalidades pós-coloniais, o encontro entre categorias abstratas da Filosofia e o senso comum.

No caso dos modernismos brasileiro e cabo-verdiano, coube sobretudo a Bandeira e aos claridosos, respectivamente, promover o encontro dos temas originais de cada país, tomados da cultura popular, com formas igualmente originais de expressão, obtidas, na poesia, sobretudo pela flexibilização progressiva do verso.

Não se pode conceber a consolidação de uma estética realmente modernista no Brasil sem que houvesse, de fato, um trabalho de pesquisa que levasse à descoberta de modelos próprios de expressão literária, fazendo, assim, convergir imaginação material e imaginação formal, pois

se no plano temático, algumas das mensagens de 22 já estavam prefiguradas na melhor literatura nacionalista de Lima Barreto, de Euclides e de Lobato, o mesmo não se deu no nível dos códigos literários que passam a registrar inovações radicais só a partir de Mário, de Oswald, de Manuel Bandeira. (BOSI, 1994, p. 345)

Mesmo Olavo Bilac, defensor primaz da "Deusa serena, / "Serena forma", como expressou em sua "Profissão de Fé", dedicou-se a temas nacionalistas, como o bandeirantismo ("O Caçador de Esmeraldas") ou, de modo mais acerbo, o louvor aos símbolos pátrios, como as armas nacionais e a bandeira, de cujo hino foi ele próprio, Bilac, autor, em parceria com Francisco Braga. Mas, mesmo tratando-se de temática brasileira, não se observa um vínculo profundo entre o conteúdo e sua própria forma de expressão, já que Bilac "Define a palavra como algo que não se identifica com a substância das coisas, mas 'veste-a' magnificamente." (BOSI, 1994, p. 227). 
Essa forma superficial de escrita, em que um aparato estético pré-determinado impede qualquer possibilidade de mudança, permitiu que alguns temas tomados do repertório romântico, como a palmeira, símbolo da nacionalidade, fossem glosado em moldes alexandrinos, como o fez Alberto de Oliveira. Educado pelas cartilhas parnasianas, não se nota em seus versos qualquer aproximação com registros populares, empregados, ainda que timidamente, pelos românticos, dos quais tomara tal tema. E, o que é mais significativo, não há indícios das flexibilizações rítmicas introduzidas pelos simbolistas, que desembocariam, anos mais tarde, no verso livre modernista.

Como no Brasil, autores cabo-verdianos já vinham abordando, desde o final do século XIX, temas caracteristicamente locais, fazendo-o, contudo, por meio de modelos literários europeus. No século XX, poetas anteriores à Claridade, como António Pedro, não deixaram de abordar temas cabo-verdianos, como o "mar" (“Canção dum mar ao largo") e "as rochas escalvadas" ("embora fosse careca / a terra seca, / e o sol queimasse / e adormentasse / já."), cantados, em meio aos dramas locais (hora di bai), também por Eugênio Tavares em sua obra em crioulo. Caberia aos claridosos, em seqüência, a tarefa de encontrar para esses conteúdos cabo-verdianos já expressos em modelos europeus formas originais de expressão, pois o "encontro de poetas com a face verdadeira da vida acontece mercê da alquimia conteúdo-forma na transfiguração encantatória da realidade cabo-verdiana." (FERREIRA, 1975, p. 75).

Em seqüência ao Simbolismo, os poetas penumbristas, incluindo-se entre eles o Bandeira de A Cinza das Horas e Carnaval, com sua estética, como temos afirmado, de transição, promoveu mudanças semelhantes ao fazerem confluir progressivamente temas crepusculares (imprecisão de sentimentos, ambientes de iluminação difusa, luscofusco dos fins de tarde) e formas de atenuação das regras poéticas vigentes (deslocamento dos acentos rítmicos, adjetivos imprecisos). Aparentemente despretensiosos em sua maneira de agir, os poetas penumbristas mostraram extremamente importantes no processo de transição para o Modernismo, pois

Fazendo uma poesia voluntária e sinceramente menor, o crepuscularismo ${ }^{16}$ foi responsável pela erosão da métrica acadêmica e de toda a retórica oitocentista, levando à prática do verso livre, pedra de toque das poéticas modernas. (BOSI, 1994, p. 267). 
Opinião semelhante à de Goldstein, para quem

\begin{abstract}
Paralelamente, os poetas crepusculares praticam a desarticulação do verso por via do ritmo dentro da métrica tradicional, chegando a modificá-la. Poderíamos falar, portanto, num processo de meio-tom formal correlacionado a um processo de meio-tom psicológico. (1983, p. 3)
\end{abstract}

Para Rodrigo Otávio Filho, o Penumbrismo constituiu um "nítido exemplo de literatura de transição ou intermediária.” (apud COUTINHO, 1969, p. 219); para Bandeira, haveria entre seus autores uma espécie de "amor das meias-tintas" (1957, p. 120); para Ronald de Carvalho, tratou-se de uma literatura "feita de sons velados, de surdinas, de tons menores" (1931, p. 71), imagem semelhante à de Bosi, para quem os penumbristas "abafaram o pedal das excessivas sonoridades a que se haviam acostumado os imitadores de Cruz e Sousa" (1994, p. 269).

Entre sons velados, surdinas, meios-tons e meias-tintas, surge uma "estética da atenuação" (GOLDSTEIN, 1983, p. 10), manifesta tanto na temática, com a substituição da grandiloqüência épica parnasiana por assuntos tomados do cotidiano humilde, quanto em aspectos variados da construção formal.

Destacam-se, nessa estética da atenuação, expedientes de diluição (ou dissolução, como diria Bandeira) das estruturas rítmicas, com o uso recorrente de versos polimétricos, deslocamento de acentos tônicos e dupla possibilidade de leitura dos versos.

A atenuação sensorial é se faz presente sobretudo em poemas descritivos, com recorrente escolha de ambientes de iluminação parcial (sombra, penumbra, crepúsculo, vésper) e sonoridades veladas (meio-tom, murmúrio, lamento).

Ainda no plano sonoro, são comuns as rimas toantes, profusamente utilizadas em Carnaval (1919) com o intuito de se obter, segundo declarou o próprio Bandeira (1984, p. 16), os mesmos efeitos de atenuação sonora alcançados pelo decadentista francês Charles Guérin.

Adjetivos e advérbios operam atenuações semânticas nos substantivos e verbos que acompanham, promovendo uma espécie de modalização menor dos sentidos, tornando-os menos específicos, algo que Balakian já observara entre os simbolistas franceses (1985, p. 53).

\footnotetext{
${ }^{16}$ Seguindo a tradição italiana, Bosi opta pelo termo "Crepuscularismo" ( ), ao invés de "Penumbrismo",
} 
Consciente ou inconscientemente, os autores penumbristas, com sua estética da atenuação, foram responsáveis pela lenta erosão do rigorismo formal parnasiano, dando suporte ao surgimento de modos de expressão que, ao mesmo tempo em que se distanciavam de artificialismos, aproximavam-se de registros populares de cultura.

Desde seu primeiro livro, Bandeira mostrou-se um entusiasta da naturalização das formas poéticas, o que não escapou à fina sensibilidade crítica de Ribeiro Couto, que, em um discurso acadêmico, saudou da seguinte forma a estréia do pernambucano:

\begin{abstract}
A Cinza das Horas, pequenino volume, é neste momento um grande livro. De tal arte nos haviam estragado o gosto com o abuso das convenções, dos artifícios e das nigromancias mais esdrúxulas, que esta volta à simplicidade e ao natural é uma reparação consoladora e saudável. Saindo daquele atordoamento de luzes multicolores, de lanternas nipônicas, reentramos com o poeta no frescor ameno das sombras. (apud BRITO, 1997, p. 81)
\end{abstract}

Invertendo-se os papéis, vemos que não é muito diferente a opinião do crítico Bandeira sobre o poeta Ribeiro Couto, considerado pelo pernambucano um "mestre do alexandrino "desparnasianizado"” (1966b, p. 284), já que flexibilizara tal tipo de verso ao compô-lo sem a cesura mediana, obrigatória segundo os preceitos da escola de Bilac.

Tal processo de recuperação da naturalidade das formas poéticas, em oposição ao artificialismo parnasiano, já se iniciara, ao menos no que diz respeito ao ritmo, com o Simbolismo. Na obra de Cruz e Sousa, "o metro perde o rigor exigido pelo Parnaso e, ainda que predomine o soneto e, portanto, o decassílabo, este afrouxa o ritmo, deslocando os acentos tradicionais." (BOSI, 1994, p. 273). Já Alphonsus de Guimaraens, "tradutor de Heine e de poetas chineses, lidos em versão francesa, experimenta novos arranjos rítmicos ou trata com ciente frouxidão velhos metros medievais, tendência que, nascida com o Simbolismo europeu, iria desaguar no verso livre.” (BOSI,1994, p. 280)

Resultante da aproximação com registros populares de cultura, a "incorporação da poesia africana à poesia brasileira" (BASTIDE, 1997, p. 38) merece destaque nesse processo de flexibilização rítmica. Para Bastide,

O que caracteriza o estilo da África é a força do ritmo; até se pode dizer que sua arte é apenas ritmo. Ora, este não obedece a uma regra artificial imposta pelas convenções do homem; está em uníssono com o ritmo cósmico ou do organismo humano; acompanha os movimentos respiratórios ou os jogos do

mais comumente usado no Brasil. 
músculo dançante. Assim, não podia exprimir-se, sem perder seu caráter, nas formas tradicionais do octo ou do decassílabo, ou do alexandrino. Para que ele pudesse transformar-se em poesia, foi necessário, portanto, que primeiro se destruíssem os moldes antigos; foi preciso que o ritmo reencontrasse sua autonomia. (1997, p. 38)

No Romantismo de estro social, como no caso emblemático de Castro Alves, por exemplo, embora o tema da escravidão passe a ser dos mais significativos, não há uma transformação estética equivalente, já que "a incorporação da poesia negra à poesia nacional, não podia produzir-se enquanto existisse a escravidão, a qual impedia que essa poesia se mostrasse, afastava-a, escondia-a no escuro da senzala." (BASTIDE, 1997, p. $30)$.

Obstruída pelo rigorismo parnasiano, a rítmica africana começaria a ser sentida nos versos dos principais simbolistas. José Veríssimo, mesmo sendo um crítico ferrenho de Cruz e Sousa, em cuja obra não via, a princípio, mais do que outro rebento do decadentismo europeu, reconhece em seus versos um sentimento "da música das palavras, do dom de melodia, que é comum nos negros.” (1907, p. 168)

Pouco depois, já entre os modernistas, a aplicação de ritmos de origem africana é evidente em poemas de Bandeira como "Berimbau", cujo título, que não guarda qualquer relação com o tema amazônico do texto, serve apenas de índice da estrutura rítmica adotada, a qual busca reproduzir, com o auxílio de aliterações e assonâncias, o toque do instrumento afro-brasileiro. Eis, a título de ilustração, a primeira estrofe:

Os aguapés dos aguaçais

Nos igapós dos Japurás

Bolem, bolem, bolem.

Chama o saci:_ Si si si si!

_ Ui ui ui ui ui! uiva a iara

Nos aguaçais dos igapós

Dos Japurás e dos Purus.

(BANDEIRA, 1993, p. 120)

Tal procedimento de estruturação rítmica foi explorado também por Jorge Barbosa em poemas como "Rumores": 
(...)

Rumores musicais das mornas

dançadas,

das mornas

tocadas,

das mornas

cantadas...

(...)

(BARBOSA, 2002, p. 44)

e "O Baile":

No baile

A morna

Entorna

Dolências...

O rabequeiro

Compassa

A música,

Batendo a planta descalça

No chão.

E os pares

Giram

Apertados

Uns contra os outros,

Levados

Na morna...

(...)

(BARBOSA, 2002, p. 332)

Em ambos os trechos acima transcritos, a interpenetração da estrutura musical se mostra pela forte marcação rítmica binária dos versos curtos, "compassados", no caso de "O Baile", pela figura do rabequeiro, central nos conjuntos de morna. Essa mesma 
estrutura rítmica pode ser observada em um poema homônimo de Casimiro de Abreu, brevemente analisado por Bandeira no Itinerário de Pasárgada (1984).

É significativo o fato de poetas cabo-verdianos se mostrarem receptivos à poesia de alguns autores brasileiros, como Bandeira e Jorge de Lima em um momento em que há justamente uma valorização formal de ritmos africanos. Naturalmente, buscava-se no Brasil, afinal, o que Portugal não podia oferecer raízes africanas comuns.

Ao traçar estratégias para a análise das relações literárias entre Brasil, África e Portugal, Salvato Trigo destaca a existência de um duplo percurso de trocas, pelo qual, elementos estéticos vindos da Europa para o Brasil seguiriam, em seguida, para as nascentes literaturas africanas. Diz ele:

Dum ponto de vista histórico-literário, poderíamos dizer que o movimento que conduz à emancipação literária do Brasil e das colônias de África faz uma dupla travessia atlântica. Com efeito, a migração estético-literária fazse da Europa para o Brasil e daqui para a África. (s./d., p. 28)

Embora não descartando a pertinente "dupla travessia atlântica" de Trigo, podemos imaginar, a partir da experiência de incorporação dos ritmos africanos pela poesia brasileira, que acabam por ecoar em Cabo Verde, uma outra travessia, igualmente dupla e atlântica. Desta vez, no entanto, elementos africanos secularmente transplantados para o Brasil cruzam o oceano e contribuem, decisivamente, para a emancipação da literatura cabo-verdiana ante os cânones metropolitanos. 
CAPÍTULO 4:

De Terra-longe a Pasárgada: a Supressão Utópica não merece sequer ser olhado."

(Oscar Wilde) 


\section{1 "Plonger au fond du gouffre"}

Para Balakian (1985, p. 126), o tema central do Simbolismo foi a luta do homem, do artista, sobretudo, contra o vazio. Presente já em Baudelaire, de cujos versos extraímos o presente subtítulo, o sentimento de gouffre, de melancólica queda no abismo, intensifica-se no Decadentismo, quando o embate entre o homem e a técnica, em meio à segunda Revolução Industrial, é levado ao extremo.

Do Decadentismo, emerge um sentimento de "inquietação metafísica", que, presente já em Baudelaire, encontrou guarida nos versos de não poucos poetas modernos identificados com um sentimento de gouffre, termo ambíguo que encerra as idéias de "abismo, profundidade, desvio da normalidade, fronteira: entre visível/invisível, consciente/inconsciente, vida/não-vida, de vazio, de espelho _ ou desdobramento do 'eu' _ de negação.” (GOLDSTEIN, 1983, p. 5).

Frutos sazonados do Simbolismo tardio, os poetas penumbristas brasileiros, dentre os quais o Bandeira de A Cinza das Horas, quando já se entremostram muitas das características que o acompanhariam, de um modo ou de outro, nos livros seguintes, responderam ao sentimento de gouffre por meio de uma atitude de evasão,

reação ao predomínio das coisas sobre o homem: refreada no homem comum, ela aparece no plano poético sob a forma de fuga doentia, de refúgio no campo, de evocação da infância, [...], de desejo de repouso e abandono, de alheamento. (GOLDSTEIN, 1983, p. 6)

No limite, a arte seria "a única indenização verdadeira para as desilusões da vida, [...] a autêntica realização e perfeição da existência, que é imperfeita e inarticulada em si mesma." (HAUSER, 1968, p. 218).

\subsection{Mímica do ausente: o caráter supressivo da utopia}

Desde A República de Platão, estabeleceu-se na literatura ocidental uma linhagem de narrativas ou discursos utópicos cuja finalidade, em última análise, é esboçar sociedades ideais, imaginadas a partir do espaço de enunciação de onde se 
originaram. Entendidas como discursos literários, as utopias reconstroem, a partir da ausência, o que foi social ou particularmente negado.

Como na mímica, em que a linguagem gestual faz surgir, pela sugestão dos contornos, objetos que, embora conhecidos, estão ausentes, o discurso utópico, trazendo em seu bojo a memória daquilo que houve e já não há, daquilo que, tendo-se anunciado, não se pôde cumprir ("a vida inteira que podia ter sido e que não foi”), reconstrói pelo texto o que não tem lugar na vida real. Mas, mais do que um mero dispositivo de alienação, a utopia enriquece o sujeito ao potencializar-lhe a ação futura: "O que não tenho e desejo / é o que melhor me enriquece", escreveu Bandeira.

Ao forjar o termo utopia, aceito por esferas eruditas e populares a ponto de transpor-se de topônimo a substantivo abstrato de uso regular, More tinha em mente não apenas o sentido mais evidente de negação do espaço, $\boldsymbol{u}$ ('não'), topos ('lugar'), mas o trocadilho que se podia estabelecer com eutopia, 'lugar feliz'. Negar o espaço (e, portanto, o contexto pessoal ou social dos que nele se inserem) (re)contruindo, pelo discurso, o que está ausente, pode ser uma estratégia de busca da felicidade, uma “promesse de bonheur”, definição do Belo para Sthendal.

Ernst Bloch, em oposição ao caráter passivo que anos de tradição cristã milenarista insuflaram nas narrativas utópicas, defende a idéia de um controle consciente da utopia, a funcionar como um "sonho diurno", sobre o qual agiria a vontade do sujeito, instrumentalizando-se para a construção de seu próprio futuro. Seria, em sua expressão, a “utopia concreta” (apud MÜNSTER, 1993, p. 24).

Gert Ueding, estudioso da obra de Bloch, reconhece em sua teoria uma associação intrínseca entre o próprio caráter ficcional da literatura e o sentimento utópico, que, na modernidade, acabaria por assumir um papel compensatório ante a falta de perspectivas:

Literatura é Utopia, num sentido muito amplo, é claro, uma vez que ela não é idêntica à realidade que nós encontramos na natureza e na sociedade. É Utopia no sentido muito preciso de que sua conexão com esta realidade é como a da satisfação de uma necessidade. (apud BLOCH, 1988, p. XXXIIXXXIII)

Para Levitas (1990, p. 181), o discurso utópico surge exatamente no interstício que se abre entre o que é necessário ou desejado e a possibilidade de satisfação. Marcuse, em termos psicanalíticos, entende que a escrita utópica é regida por uma 
espécie de criatividade inconsciente, ativada pelo conflito que se instaura entre o fetiche, síntese daquilo que se deseja, e o dado concreto da realidade, que obsta sua plena realização.

Como tentativa de superação do impasse, verifica-se um apego incondicional a determinados objetos ou símbolos que dão forma ao desejo inatingível, como a imagem da estrela, obsessiva na obra de Bandeira:

\title{
Eu quero a estrela da manhã \\ Onde está a estrela da manhã? \\ Meus amigos, meus inimigos \\ Procurem a estrela da manhã.
}

(BANDEIRA, 1993, p. 149)

Perpassando quase toda sua obra, da Estrela da Manhã à Estrela da Tarde, e, finalmente, Estrela da Vida Inteira, a estrela passa a se identificar com a própria busca do poético, que, no caso de Bandeira, constituiu sua maior razão de existir.

Em seu poema "Carta para Manuel Bandeira", é justamente a estrela da manhã que move Jorge Barbosa de um lado a outro do Atlântico. Em um gesto solidário, pressentindo a solidão de Bandeira, diz o poeta cabo-verdiano:

\author{
Eu faria por ti qualquer cousa impossível. \\ Era capaz de procurar a Estrela da Manhã \\ por todos os cabarés \\ por todos os prostíbulos. \\ E eu ta levaria \\ pura ou degradada até à última baixeza.
}

(BARBOSA, 2002, p. 131)

E, após a travessia atlântica:

Então
sem qualquer palavra
passar-te-ia a Estrela da Manhã.

(BARBOSA, 2002, p. 132) 


\subsection{Saudades de amanhã: utopia como negação do presente}

As utopias humanistas do século XVI, das quais a de More é o exemplo mais conhecido, inserem-se em um contexto de expansão das fronteiras espaciais do mundo, fruto das grandes navegações, sobretudo de portugueses, como o próprio Rafael Hitlodeu, protagonista de More.

Herança do cristianismo medieval, acreditava-se que haveria, no extremo do mundo, um local, provavelmente uma ilha, que se teria preservado da decadência desencadeada pelo pecado original.

A associação entre utopia e éden, comum nas crônicas descritivas coloniais, encontrou seus cultores tanto no Brasil quanto em Cabo Verde, sobretudo no Romantismo, quando são abundantes as descrições de uma natureza exuberante e paradisíaca, preservada da ganância da exploração industrial. Não por acaso, as "canções do exílio" de Gonçalves Dias ou Casimiro de Abreu têm como pontos de referência positiva da terra natal elementos naturais: a palmeira, o sabiá, os bosques, as flores. Romantismo que deixa traços no século XX, como no poema "A Terra", de Jorge Barbosa, em que se descreve, ingenuamente, uma exuberância de frutas, todas, aliás, exóticas, em um país árido:

Terra fértil das bananeiras,

das laranjeiras,

dos acajus,

dos cafeeiros, das uvas, dos batatais;

do milho que dá cachupa, o cuscuz,

a batanca, o gufongo; das canas

que dão o grogue e o mel...

(BARBOSA, 2002, p. 41)

Com a modernidade, conhecidas e estabelecidas as fronteiras do mundo, o eixo central dos discursos utópicos move-se da categoria de espaço para a de tempo. Mais do que um espaço edênico no extremo do mundo, a utopia passa a ser, sobretudo, a memória dos tempos idos ou a expectativa do que virá. 
Bachelard (1989b, p. 112), analisando as relações entre as categorias de tempo e espaço, chega à conclusão de que elas não estão necessariamente interligadas; assim, a um 'aqui', espaço em que se está, não corresponde, necessariamente, um 'agora', tempo em que se vive.

O fato de que espaço e tempo não estão necessariamente acoplados abre margem à possibilidade de se reconstruir, na linguagem, aquilo que está no passado e cuja ausência traz ao indivíduo um sentimento inevitável de perda.

A escrita é o principal instrumento de guia na busca pelo tempo perdido e por aquilo que, com ele, perdeu-se igualmente. "O que é perdido, na existência e na memória, recupera-se no exercício do canto" (ROSENBAUM, 1993, p. 120), dado que “o contínuo da melodia e o contínuo da poesia são reconstruções sentimentais que se aglomeram em lado diverso do da sensação real, graças ao difuso e ao torpor da emoção, graças à mistura confusa de lembranças e esperanças.” (BACHELARD, 1989b, p. 113).

Para BOSI, mais do que um dado dos textos utópicos, a recuperação do tempo pela memória fundamenta a própria essencialidade poética:

\footnotetext{
A instância poética parece tirar do passado e da memória o direito à existência; não de um passado cronológico puro _ o dos tempos já mortos _, mas de um passado presente cujas dimensões míticas se atualizam no modo de ser da infância e do inconsciente. (1977, p. 112)
}

Naturalmente, o tédio, que, com outros elementos, desencadeia a saudade enquanto recurso de "autonegação do presente" (LOURENÇO, 1999, p. 16), conduz, também à melancolia. Mas, embora pertença à mesma constelação psicológica da tristeza, da angústia e do tédio (LOURENÇO, 1999, p. 32), a saudade propicia uma temporalidade construída a partir da memória, a qual opera como um lenitivo ao substituir as agruras do tempo presente pela felicidade do passado. Recordar é viver, trazer de volta ao coração, literalmente, o que nele não mais reside. Um "veneno gostoso", para Osvaldo Alcântara, ou, na expressão de Teixeira de Pascoaes, um "delicioso pungir".

Também em Osvaldo Alcântara, a saudade, associada à idéia mítica de Pasárgada, cumpre um papel de negação ou suspensão do tempo presente, como se vê no poema "Itinerário de Pasárgada", que transcrevemos na íntegra: 
Saudade fina de Pasárgada...

Em Pasárgada eu saberia
onde é que Deus tinha depositado
o meu destino...

E na altura em que tudo morre...

(cavalinhos de Nosso Senhor correm no céu;

a vizinha acalenta o sono do filho rezingão;

Tói Mulato foge a bordo de um vapor;

o comerciante tirou a menina de casa;

os mocinhos da minha rua cantam:

Indo eu, indo eu,

a caminho de Viseu...)

Na hora em que tudo morre, esta saudade fina de Pasárgada

é um veneno gostoso dentro do meu coração.

(apud ANDRADE, 1975, p. 32)

O mesmo tédio, capaz de levar à angústia, responde, nesse texto, por uma tentativa de figuração poética da suspensão temporal, compensando, por meio da construção estética, a melancolia experimentada pelo eu-lírico.

Logo no primeiro verso, destacado dos demais, compondo isoladamente uma estrofe completa, tem-se uma frase nominal, pela qual se anuncia, de modo estático, o assunto do texto: a saudade de Pasárgada. Trata-se de um sentimento ambíguo, já que em sequiência ao substantivo abstrato que o expressa, "saudade", tem-se um adjetivo atenuador, "fina", cujos sentidos podem ser vários: aguda, intensa, afilada, sutil, delicada. O par assim composto, "saudade fina", repete-se ao final do poema, sendo definido por outro par ambíguo, "veneno gostoso".

$\mathrm{Na}$ segunda estrofe, tem-se, de um certo modo, a explicação ou a justificativa da "saudade fina de Pasárgada”, mola propulsora do poema, anunciada na estrofe anterior. 
Aqui, reforça-se a impressão de suspensão temporal provocada pela frase nominal que abre o poema, seguida de reticências que se repetem também no fim da segunda estrofe. Os verbos 'saber' e 'ter', que, no põem, não expressam ações, propriamente ditas, sugerem hipóteses, e não certezas ("eu saberia: futuro do pretérito; "onde Deus tinha depositado": imperfeito empregado como futuro do pretérito).

O tempo do presente, expresso por ações repetitivas do cotidiano ("correm", “acalenta”, "tirou”, “foge”, “cantam”, “indo”), está confinado à terceira estrofe, no bloco central do poema, isolado graficamente dos demais por vir entre parêntesis. Temse, aqui, uma espécie de grande angular cinematográfica a apreender, de um único golpe, um quadro cotidiano das ilhas, cujo efeito final, dado o caráter repetitivo das ações, é uma sensação de tédio e melancolia, atenuada, na estrofe seguinte, pela lembrança consoladora de Pasárgada.

Muito diferente seria, anos mais tarde, a postura dos antipasargadistas, que, afinados com a poesia social de meados do século, esforçam-se, como o Drummond de Sentimento do Mundo (1940) ou A Rosa do Povo (1945), por se caracterizar como homens de seu tempo.

Também na música cabo-verdiana, passado e presente se interpenetram. Em "Roma crioula", canção de Teófilo Chantre gravada por Cesária Évora ${ }^{17}$, o compositor compara a cidade do Mindelo a Roma, por serem ambas cidades que, tendo experimentado um passado glorioso, amargam um presente de decadência. Após descrição da "fasi di oro" do porto do Mindelo, da "era d'esplendor", cujos traços seriam ainda reconhecíveis na arquitetura e no ambiente cosmopolita, Chantre lança, na estrofe final, seu brado utópico de negação do presente, projetando, no futuro, o passado glorioso que ele descrevera:

Se Mindelo um vez era sabe

Inda el ta ser mas sabe ${ }^{18}$

\footnotetext{
17 Álbum Café Atlântico, Selo Lusáfrica, RCA, 1999.

${ }^{18}$ Tradução livre: "Se Mindelo um dia foi bom, será ainda melhor".
} 


\subsection{Rondó de um aporrinhado}

Entre os anexos publicados por Ancona-Lopez em Manuel Bandeira: verso e reverso (1987), inclui-se uma cópia fac-similar de uma versão autógrafa de "Vou-me embora pra Pasárgada” enviada pelo poeta pernambucano a Mário de Andrade em $1927^{19}$. À parte algumas pequenas alterações no corpo do texto, chama a atenção nesse manuscrito o fato de o poema vir com dois títulos: o definitivo "Vou-me embora pra Pasárgada", que se consagraria com a publicação em livro pouco mais tarde, e "Rondó do aporrinhado", o qual, embora excluído, por fim, fornece um índice do estado de espírito que desencadeou a composição do poema e da forma escolhida para tanto (um rondó, modelo musical em que um determinado motivo mostra-se recorrente ao longo do tempo, como a redondilha que dá titulo ao poema).

"Vou-me embora pra Pasárgada" foi, como declara o próprio Bandeira, seu poema de mais longa gestação, e, talvez por isso, o que melhor resumiria suas próprias convicções a respeito da criação literária. Mais tarde, ao escrever sua biografia poética, Bandeira intitulou-a, não por acaso, de Itinerário de Pasárgada, como se os caminhos do poema fossem ou, ao menos, cruzassem os de toda sua obra.

Nas primeiras páginas do Itinerário, Bandeira deixa claro o fato de ter se tornado poeta pela necessidade de preencher, pela arte, o vazio provocado pela doença. Após uma breve e pueril experiência com os versos, sua vida parecia rumar para uma tranqüila carreira de arquiteto. Logo surgiriam, no entanto, os sintomas e o diagnóstico da então temível tuberculose e, em seu rastro, a necessidade de tratamento intensivo e a interrupção do que fora planejado. E, para preencher o vazio que se instaurou, valeu-se o poeta novamente dos versos, que o acompanhariam por toda a vida. Eis suas próprias palavras:

\footnotetext{
Pensava que a idade dos versos estava definitivamente encerrada. Ia começar para mim outra vida. Começou de fato, mas durou pouco. No fim do ano letivo adoeci e tive de abandonar os estudos, sem saber que seria para sempre. Sem saber que os versos, que eu fizera em menino por divertimento, principiaria a fazê-los por necessidade. (BANDEIRA, 1984, p.20)
}

\footnotetext{
${ }^{19}$ Manuscrito pertencente, hoje, ao Arquivo Mário de Andrade do Instituto de Estudos Brasileiros da Universidade de São Paulo. Sua fotografia foi publicada na edição crítica da correspondência entre Mário de Andrade e Manuel Bandeira, organizada por Marcos Antônio de Moraes.
} 
Longe de se entregar passivamente, Bandeira buscou, pela literatura, reconstruir textualmente um universo pleno de tudo aquilo que lhe fora negado e, para tanto, fez surgir em seu universo poético, como grande símbolo desse farto espaço imaginário, o mito de Pasárgada, antiga cidade de veraneio de Ciro, agora repleta do que fora negado ao poeta: banhos de mar, pau-de-sebo, prostitutas bonitas, um lugar, enfim, "onde podemos viver pelo sonho o que a vida madrasta não nos quis dar." (BANDEIRA, 1984, p. 98).

Também em suas crônicas Bandeira se refere a Pasárgada, em contextos diferentes, como um expediente compensatório. Sobre o cinema, diz ele tratar-se de "pasárgada de imagens para o homem comum", por servir como "ilusão compensatória de tudo aquilo de que ele se sente frustrado na vida." (BANDEIRA, 1966b, p. 135).

Tem-se, pois, no caso de Bandeira, um fazer poético que, ao menos em seu princípio, funcionou como "uma primeira solução para um drama interior" (BASTIDE, 1997, p. 57), solução que, em linguagem figurada, equivaleria a "agarrar-se a uma balaustrada para não cair no abismo.” (BASTIDE, 1997, p. 60)

A redondilha maior que compõe o título do poema surgiu, segundo declaração do próprio Bandeira, instintivamente, como um brado libertário "num momento de fundo desânimo" (BANDEIRA, 1984, p. 97). Após um longo período de incubação, o mais longo na carreira poética do autor, surgiram as demais redondilhas do poema, "em idênticas circunstâncias de desalento e tédio.” (BANDEIRA, 1984, p: 98).

Em "Vou-me embora pra Pasárgada", a idéia de um tempo recorrente, em que imagens do passado compõem uma expectativa de futuro, pode ser percebida desde o modelo formal escolhido por Bandeira. $\mathrm{O}$ título do poema, que se repete no primeiro verso e outras cinco vezes ao longo do texto, funciona como um refrão, a impedir que a motivação primeira do eu-lírico, a lembrança utópica de Pasárgada, caia no esquecimento.

Para Bloch, seria possível, pela literatura de natureza utópica, reagir diante da iminência da morte ou da "sensação de que múltiplos projetos fracassaram" (1988, p. 12). Dessa forma, "o que deveria ser" (it should be), mesmo obstruído pela condição do presente, encontraria no texto utópico uma expectativa futura de realização.

Entendemos que tal mecanismo rege o esforço de negação do tempo presente em "Vou-me embora pra Pasárgada". O que se observa no poema, à revelia do momento de enunciação desfavorável, é o passado, configurado, metonimicamente, pela memória 
dos folguedos da infância; e a expectativa do futuro, em que os dias de alegria novamente terão lugar:

E como farei ginástica

Andarei de bicicleta

Montarei em burro brabo

Subirei no pau-de-sebo

Tomarei banhos de mar!

(BANDEIRA, 1993, p. 143)

Nesse trecho, a construção, como as formas verbais o indicam, é evidentemente futura ("farei", “andarei”, montarei", "subirei”, "tomarei”), mas o repertório de imagens é fornecido pela memória da infância, que se presentifica, no texto, pela própria lembrança.

Como os elementos da construção poética, que se repetem continuamente, como palavras ou mesmo versos inteiros podem e devem reaparecer no corpo do texto, também a infância dos burros brabos e dos paus-de-sebo podem ter lugar novamente, à revelia da condição presente que o impede.

\subsection{Da utopia pessoal à res publica}

Diferentemente da maioria das narrativas utópicas, em que se constrói, pela escrita, uma coletividade pública (uma res publica, como as Repúblicas de Platão e Thomas More), Pasárgada é uma utopia construída a partir do indivíduo. O eu-poético vale-se, para sua satisfação pessoal, da relação de amizade mantida com o rei, o qual, pelo favor, franqueia-lhe o acesso ao que quer que seja. Diferentemente de Platão e de More, cujas narrativas utópicas são feitas a partir de uma visão externa, de alguém que não pertence necessariamente ao espaço utópico, mas que transita por ele, a Pasárgada de Bandeira nos é dada a conhecer por alguém que se mostra íntimo ao local, um amigo do rei. 
Também as marcas lingüísticas de primeira pessoal são abundantes e não deixam dúvida quanto ao caráter de compensação pessoal, e não coletiva, de que se reveste o poema "Vou-me embora pra Pasárgada".

Mas, admitindo-se o fato de que a Pasárgada de Bandeira surge como um mito pessoal, com o intuito de satisfazer necessidades e carências específicas de um amigo do rei, como explicar sua grande popularidade, ou, o que é mais impressionante, sua transmutação a mito coletivo em Cabo Verde?

Berrini (1997), que estudou especificamente a recepção do poema nos países de língua portuguesa, destaca, entre outros recursos, o uso de léxico e de construções sintáticas simples ('pra' em lugar da preposição 'para'; verbo 'ter' com sentido impessoal de 'haver') e o apelo a uma realidade concreta tangível (burro brabo, pau-de-sebo, telefones automáticos, prostitutas).

A construção do poema em moldes populares, seja pelo uso da redondilha, seja pelo modelo do rondó e suas recorrências sonoras, aproxima-o da oralidade e confere a ele um poder mnemônico extraordinário. Desobstruído da escrita, o poema mergulha na memória coletiva da língua, sendo um dos mais conhecidos, memorizados e recitados, a exemplo da "Canção do exílio" de Gonçalves Dias, com o qual, não por acaso, dialoga intertextualmente.

Como no poemeto romântico, a organização espacial é feita pelos pares antitéticos que sintetizam a satisfação ou a insatisfação do eu-lírico:

as aves que aqui gorjeiam

não gorjeiam como lá.

(DIAS, 1926, p. 87; grifos nossos)

aqui eu não sou feliz

lá tenho a mulher que eu quero

(BANDEIRA, 1993, p. 143; grifos nossos)

A idéia de que o poema de Bandeira está arraigado à memória coletiva da língua comprova-se pela grande e positiva receptividade por ele experimentada também em 
Portugal, tendo a revista Távola Redonda dedicado, na década de 1950, um número inteiro exclusivamente a "Vou-me embora pra Pasárgada".

\subsection{O mito de Pasárgada em Cabo Verde}

Com relação a Cabo Verde, sabe-se que a privação natural a que sempre estiveram sujeitos seus habitantes acabou por empurrá-los para o exílio físico ou para a evasão, num movimento dialético incapaz de ser satisfeito. Para essa dialética, que passou à posteridade com o nome de "terralongismo", Manuel Ferreira propôs o seguinte esquema:

TERRALONGISMO オ

Emigração: origem econômica; motivação real.

Evasionismo: origem intelectual; motivação real ou ideal.

(FERREIRA, 1986; adaptado)

Qualquer que seja o eixo tomado, o que se vê é um desacordo entre o que se deseja e o que dita a realidade imediata, sempre insatisfatória, ou, como sugeriu Benilde Caniato no seguinte trecho, valendo-se também da dialética do terralongismo, provisória: "Viver em Cabo Verde é, permanentemente, 'querer ficar e ter de partir' e também 'querer partir e ter de ficar', em que qualquer decisão será sempre provisória". (CANIATO, 1980, p. 100)

O resultado dessa inconstante condição é uma impressão de isolamento, em meio a uma imprecisão de sentimentos, em que se mesclam humildade, monotonia, desassossego, medo, saudade, nostalgia, revolta, melancolia, esperança, substantivos abstratos profusamente encontrados nas páginas dos três primeiros números da Claridade.

$\mathrm{Na}$ literatura, várias foram as reações a esse estado incerto de espírito, mas o objetivo, um só: uma possível compensação, que, sabe-se, nunca será plena. Mas permanecem todos, segundo Gabriel Mariano, "procurando, cada um a seu modo, compensar o desejo frustrado". (MARIANO, 1991, p. 33) 
Também Elsa Rodrigues dos Santos, em seu estudo sobre a poesia de Jorge Barbosa, reflete sobre esse sentimento impreciso e tão caracteristicamente caboverdiano, responsável em partes pela postura evasiva dos claridosos:

O sentimento de solidão, de nostalgia, que o ilhéu experimenta face ao isolamento e aos limites da fronteira líquida que o separam do resto do mundo, criando-lhe um estado de angústia e ansiedade que o levam a sonhar com outros horizontes para lá do mar. (1989, p. 59)

A própria morna, tantas vezes evocada como uma síntese emblemática da cultura cabo-verdiana, já apresenta, desde sua origem, um caráter também compensatório. ${ }^{20}$ Compõe-se, toca-se e canta-se para que a música ocupe o lugar, seja do(a) amado(a) que partiu, seja dos folguedos da terra natal, tantas vezes substituídos pelo trabalho árduo nos plantations de São Tomé e Príncipe.

Pensando na influência da privação natural ecológica sobre a natureza humana do cabo-verdiano, Alfredo Margarido enalteceu a importância de se conhecer a problemática social do arquipélago para então ser possível uma compreensão adequada de suas manifestações literárias. Assim,

Se queremos compreender a natureza humana, devemos acima de tudo, tentar penetrar no cerne dos conflitos que o homem é obrigado a enfrentar e que o definem. Descobrir os resultados da atividade poética propugna o paralelo conhecimento dos problemas sociais. (MARGARIDO, 1980, pp. 448-449)

O que se viu em Cabo Verde como determinação desses "conflitos que o homem é obrigado a enfrentar" foi uma postura evasiva ante a impossibilidade de se deixar o arquipélago. E, em oposição à agrura da terra natal e à intangibilidade da "terra-longe", os autores construíram, textualmente, espaços imaginários, fartos de tudo o que se queira, ideais, utópicos.

Abdala Jr, ao analisar o conto "Um galo que cantou na baía", aproxima a postura dos cabo-verdianos ao que chamou de "atualização da Utopia, no sentido de Ernest Bloch", ou seja, "é a liberação da esperança, que será truncada pelas contingências do

\footnotetext{
${ }^{20} \mathrm{O}$ que a aproxima do blues americano e dos vissungos brasileiros. A esse respeito, ver a entrevista concedida por Luís Romano a Ana Luísa Ventura Pereira para sua dissertação de mestrado.
} 
real", ou ainda "a latência do sonho nas limitações dos fatos reais" (ABDALA Jr, 1993, p. 129).

Síntese da postura utópica e evasionista assumida por Bandeira ante o que a vida lhe nega, o mito de Pasárgada gozará de grande prestígio entre os cabo-verdianos da primeira fase da Claridade, a ponto de receberem, posteriormente, a denominação de "evasionistas" (Jorge Barbosa, inclusive, foi pejorativamente designado por Onésimo Silveira de "pontífice sacrossanto do evasionismo").

Mas, longe de ser um mero índice do evasionismo ou mesmo uma imitação de uma imagem desenvolvida e explorada por Bandeira, o mito de Pasárgada mostrou-se fecundo sobretudo por sua maleabilidade, assumindo, como convém a toda grande metáfora, diferentes traços de significação.

Produto da associação natural entre a vocação marítima e as limitações impostas pelo colonialismo e pela insularidade, a postura evasionista que se entremostra no trabalho dos autores da primeira fase da Claridade nasce, paradoxalmente, da própria busca pela cabo-verdianidade. Cantada por Eugênio Tavares e por B. Lèza em suas mornas, a terra-longe ou o caminho longe que se deve percorrer para atingi-la não estiveram ausentes dos espectros temáticos de Jorge Barbosa, Osvaldo Alcântara e Manuel Lopes. Contudo, o caráter de resignação que se registra na experiência de exílio da terra-longe, responsável pelo anseio da volta, definido por Manuel Lopes como “nostalgia em estado embrionário" (CLARIDADE, 1936, n. ${ }^{\circ}$ 1, p. 6), é substituído pelo caráter reativo da evasão.

Assim, o par composto pelos espaços da terra-longe e de Pasárgada formam a síntese do "querer bi-partido" 21 cabo-verdiano, em que o primeiro termo, enraizado na tradição secular das ilhas e amplamente cantado nas mornas, evoca o desejo de querer ficar e ter que partir, e o segundo, absorvido dos versos de Bandeira, o desejo de querer partir e ter que ficar.

Mariano reconhece na poesia de Jorge Barbosa um movimento dialético entre o apego telúrico a elementos concretos diretamente ligados à vida cotidiano de Cabo Verde, como a lida com as pequenas embarcações, os faluchos, metáfora da condição dos ilhéus ("o seu instinto é um ferry-boat", afirmou Manuel Lopes no primeiro número da Claridade), e a intangibilidade dos "expedientes compensatórios" (MARIANO, 1991, p. 106) que povoam a terra-longe, distinta, para ele da Pasárgada de Bandeira,

\footnotetext{
${ }^{21}$ Expressão de Pedro Corsino de Azevedo.
} 
muito mais palpável, já que composta a partir de elementos concretos negados, pela vida, ao homem Manuel Bandeira:

Por tudo se pode concluir que a partida e a Terra-longe de J. B. se situam em planos do mais brando irrealismo. O terra-longismo de Barbosa dificilmente se assemelha com outros terra-longismos: com o pasargadismo do brasileiro Manuel Bandeira, por exemplo. Este transporta para o reino de Pasárgada todos os seus problemas concretos de homem social, de homem concreto, de homem produzido. (MARIANO, 1991, p. 111)

\subsection{Os inimigos do rei: poesia engajada e antipasargadismo}

Com o acirramento da luta pela independência política do arquipélago, "quando ninguém podia ficar indiferente a nada do que se vivia, e ou se agia sobre os acontecimentos, para os obrigar a tomar direção conveniente, ou se era agido por eles" (Alberto de Carvalho, apud MARIANO, 1991, p. 10), observou-se um progressivo engajamento da maioria dos autores às hostes revolucionárias. O evasionismo será tomado como uma fraqueza resignada dos autores de Claridade, cuja conseqüência imediata seria uma desmotivação para a luta no processo de emancipação política.

A postura crítica que tais autores demonstraram com relação aos claridosos e, naturalmente, aos seus valores e ideais literários, fez com que viessem à luz poemas, ensaios e manifestos contrários ao que se considerou, então, uma literatura evasiva, do evasionismo ou, ainda, pasargadista. Esboçado na revista Certeza, de cunho neorealista, o repúdio à postura utópica dos claridosos e, conseqüentemente, ao mito de Pasárgada, ganharia corpo com o Suplemento Cultural (1955) e com Sèló (1962), atingindo seu ponto máximo no acalorado manifesto "Consciencialização na Literatura Cabo-verdiana" ${ }^{22}$, de Onésimo Silveira. Após duras críticas ao evasionismo e ao grupo inicial de Claridade, define sua geração pela seguinte máxima, grafada em letras maiúsculas: “ESTA É A GERAÇÃO QUE NÃO VAI PARA PASÁRGADA”.

A recusa à condição colonial espalharia pela fatura dos poemas marcas estilísticas da negação, fazendo eco às palavras utilizadas por Aimé Césaire para definir o caráter de luta de sua geração: "Nós somos daqueles que sabem dizer NÃO!...” (apud FERREIRA, 1985, p. 280). A esse respeito, afirmou Trigo:

\footnotetext{
${ }^{22}$ CEI, 1963, redigido em Angola.
} 
Nascendo como recusa e alternativa à literatura colonial, as literaturas africanas têm de ser olhadas, em primeiro lugar, como uma negatividade, isto é, como um momento da dialética busca de identidade que lhes está subjacente. (s./d., p. 62)

Gabriel Mariano, um dos responsáveis pela Certeza, revista que acompanha de perto o movimento neo-realista português, é dos primeiros a se valer do recurso. Vejase, por exemplo, a estrofe final do poema "Nada nos separa", de 1958:

Não, amigos, já vos disse não!

Mais uma vez minha resposta é

Não!

Não insistam mais!

Que me importa o doce

que só a mim me dais?

Nada me separa dos meus companheiros!...

(apud FERREIRA, 1975, p. 169).

O exemplo emblemático, contudo, considerado por Onésimo Silveira como um modelo estético a ser seguido, seria o poema “Anti-evasão", de Ovídio Martins, inserido no livro Gritarei Berrarei Matarei - Não Vou para Pasárgada, de 1973, publicado em Amsterdã:

Pedirei

Suplicarei

Chorarei

Não vou para Pasárgada

Atirar-me-ei ao chão

e prenderei nas mãos convulsas

ervas e pedras de sangue 
Não vou para Pasárgada

\section{Gritarei}

Berrarei

Matarei

Não vou para Pasárgada

(apud ANDRADE, 1975, p. 48)

O tom inflamado do poema e sua exortação à luta de resistência, reforçada pela conclamação gradativamente expressa pelos verbos no futuro ("pedirei”, "suplicarei”, “chorarei”, em princípio, e "gritarei”, “berrarei”, “matarei”, por fim), deixam mensagem do poema dirige-se claramente a intelectuais engajados; desse fato, decorre a perceptível perda do referencial popular que propiciou a "Vou-me embora pra Pasárgada" seu grande alcance coletivo.

Bandeira, além da fórmula "vou-me embora", comum a várias cantigas populares brasileiras, opta pelas redondilhas maiores, metro popular por excelência, além de registros informais de escrita, como a contração "pra" e o uso impessoal do verbo "ter" com sentido de "haver", a exemplo do que fizera Gonçalves Dias em sua "Canção do exílio", já mencionada. Ovídio Martins, por sua vez, retoma a forma por extenso da preposição, "para”, e vale-se de uma mesóclise, “atirar-me-ei”, impensável em um registro popular da língua portuguesa.

A esse respeito, Hamilton (1984, p. 127) destaca a ausência, já na revista Certeza, da década de 1940, de poesia de veio popular escrita em crioulo. Assim, no lugar de uma letra de finaçon, como se viu estampada na folha de rosto de Claridade $\mathrm{n}^{\mathrm{o}}$. 1, ou de uma morna, "Vênus", na capa da Claridade n'. 2, tem-se um poema neorealista de Nuno Miranda.

Naturalmente, com a concretização da independência, deu-se o arrefecimento dos ânimos e o esforço pela (re)construção do país, "Ilha a ilha. Dor a dor. Amor a amor”, como no verso de Ovídio Martins, publicado em 1977, assume a linha de frente da produção poética.

Longe de expressar uma possível debilidade do mito de Pasárgada, a releitura que dele se fez no período das lutas de independência, ainda que negativa, pressupõe 
um potencial de flutuação de sentido que atesta o valor estético de "Vou-me embora pra Pasárgada" e assegura a seu autor um lugar de destaque na produção poética em língua portuguesa. 


\section{CAPÍtulo 5:}

Manuel Bandeira entre seus Pares 


\subsection{Manuel Bandeira e Jorge Barbosa: discursos da humildade}

\subsubsection{Batistas do Modernismo}

Antes que o grupo de autores paulistas se lançasse na empreitada que resultaria na Semana de Arte Moderna de 1922, Manuel Bandeira, dentro ainda do Penumbrismo, já vinha promovendo, sobretudo a partir do ritmo, as transformações estéticas que desembocariam no verso livre. Aludindo justamente a esse papel precursor de Bandeira para o Modernismo brasileiro, Mário de Andrade apelidou-o de "João Batista" do movimento. De fato, se imaginarmos a trajetória poética seguida pelo pernambucano, dos poemas penumbristas de $A$ Cinza das Horas à liberdade formal de Libertinagem, veremos que seu trabalho de desconstrução do verso tradicional a partir da dissolução do ritmo, como o título de um de seus livros, O Ritmo Dissoluto, sugere, inicia-se muito antes da Semana de 22.

Em Cabo Verde, pode-se observar um papel semelhante desempenhado por Jorge Barbosa, em seu primeiro livro, Arquipélago, em que já se descortinam temas, proposições e modelos formais que fundamentariam a constituição do modernismo em Cabo Verde. Publicado em 1935, pouco antes do número inaugural da Claridade, Arquipélago "abre a estrada larga do realismo cabo-verdiano" (FERREIRA, 1986, p. 38), valendo-se, para isso, do abandono de temas europeus, da renúncia às estruturas poéticas tradicionais e de uma intimidade afetiva que conferiria a sua poética um caráter de "radiografia do drama social do homem cabo-verdiano" (FERREIRA, 1986, p. 39).

Jorge Vera-Cruz Barbosa nasceu na ilha de Santiago, no ano de 1902. Após os estudos primários, mudou-se para Portugal, onde cursou até o terceiro ano de liceu. Aos dezoito anos, de volta a Cabo Verde, ingressou no serviço público como funcionário da Alfândega de São Vicente, posição que, por exigir-lhe constantes viagens pelas ilhas de Cabo Verde, deu-lhe a oportunidade de conhecer de perto as diferentes realidades do arquipélago. Faleceu a seis de janeiro de 1971 em Portugal, para onde se mudara, pouco antes, para realização de tratamento de saúde.

Autor presente em grande número de periódicos e antologias cabo-verdianas e portuguesas, foi sobretudo poeta, tendo publicado Arquipélago (1935), Ambiente (1941) e Caderno de um ilhéu (1956).

Dos três autores cabo-verdianos de que nos ocupamos, é sem dúvida o que mais referências faz a Manuel Bandeira. Em "Você, Brasil", ao descrever uma viagem imaginária 
ao Brasil (que não chegaria a conhecer), declara que "Havia então de botar uma fala / ao poeta Manuel Bandeira” (BARBOSA, 2002, p. 137). Em outra viagem imaginária, descreve o "Carnaval do Rio de Janeiro", em que, em meio à euforia da multidão que brinca, vem à lembrança a invocação, evoé, com a qual as bacantes incitavam seu deus para o início das festividades, tomada do poema "Bacanal", de Carnaval (1919),

$$
\begin{aligned}
& \text { E o verso de Manuel Bandeira } \\
& \text { ecoando cá dentro deste folião } \\
& \text { que eu já fui: } \\
& \text { _ Evoé Momo! }
\end{aligned}
$$

(BARBOSA, 2002, p. 346)

Em "Carta para Manuel Bandeira” (publicada juntamente com "Carta para o Brasil”, dedicada a Gilberto Freyre), a que fizemos menção no capítulo 4, Jorge Barbosa lança-se solidariamente na empreitada de aplacar as angústias do poeta Pernambucano levando-lhe o objeto-síntese de seu desejo, a "estrela da manhã". Nesse mesmo poema, logo na primeira estrofe, o eu-lírico declara ser pouco conhecedor da poesia de Bandeira. Diz ele:

Nunca li nenhum dos teus livros.

Já li apenas

a Estrela da Manhã e alguns outros poemas teus.

(BARBOSA, 2002, p. 131)

Tal desconhecimento ou conhecimento restrito da poesia de Bandeira é desmentido, de certa forma, por "Palavra profundamente", transcrito abaixo, em que se faz menção direta ou indireta a vários poemas de Bandeira, sobretudo de Libertinagem.

\section{PALAVRA PROFUNDAMENTE}

Há uma palavra que Manuel Bandeira descobriu um dia na Poesia e que poeta algum poderá mais empregar porque só ele ficou sabendo a seu sentido exacto 
e o simples segredo da sua expressão.

Palavra que não é Pasárgada

não é Primeva

não é nenhuma das suas

desconcertantes fantasias de evasão lírica.

Palavra profundamente.

Para a alegria de duas mãos dadas

na terça-feira do Carnaval

para a saudade de Mário Andrade ausente

para o sono

de Totónio Rodrigues

de Tomásia

de Rosa.

Poeta algum poderá mais empregá-la.

Enquanto isto

Manuel Bandeira vai passando

por nós no tempo

na sua alegria melancólica

na sua alegria de coração apertado

vai passando

na sua Poesia

profundamente.

(BARBOSA, 2002, pp. 301-302) ${ }^{23}$

Além do próprio "Profundamente", o qual, mais do que uma simples menção no título ou nas figuras de Totônio Rodrigues, Tomásia e Rosa, serviu de mote (ou motivação) ao texto de Jorge Barbosa, estabelecem a relação intertextual referências a "Vou-me embora pra

\footnotetext{
${ }^{23}$ Originalmente publicado em Claridade, No . 8, São Vicente, maio de 1958, p. 26.
} 
Pasárgada" e "Palinódia" ("primeva"), de Libertinagem, a "A Mário de Andrade ausente", de Belo belo, e ao tema do Carnaval, constante em toda a obra de Bandeira.

Publicado em 1958, mais de duas décadas depois do surgimento da Claridade, quando o poeta brasileiro já lançara todos seus livros de poemas, à exceção de Estrela da Tarde, que viria a público, parcialmente, em 1960, "Palavra profundamente" evidencia a importância da

poesia de Bandeira, especialmente de Libertinagem, mesmo depois de já consolidado o modernismo cabo-verdiano.

\subsubsection{Estratégia da simplicidade: significar o insignificante}

Consciente de que Libertinagem representava um significativo avanço estético, mesmo em comparação ao que se vinha produzindo após a Semana de 1922, Bandeira povoou o livro de poemas metalingüísticos, posicionando-se criticamente contra tudo que pudesse, por meio de regramentos artificialmente impostos, distanciar a poesia de seu viço original, conforme depreende-se do antológico "Poética":

Estou farto do lirismo comedido

Do lirismo bem comportado

Do lirismo funcionário público com livro de ponto expediente protocolo e [ manifestações de apreço ao senhor diretor

Estou farto do lirismo que pára e vai averiguar no dicionário o cunho [ vernáculo de um vocábulo

(BANDEIRA, 1993, p.129)

Tendo a forma literária sido reduzida a fôrmas pelo rigorismo parnasiano, elegeu-se desde cedo como tarefa precípua do Modernismo a busca por uma estética do desrecalque, do despojamento progressivo da escritura literária, como já analisamos no Capítulo 3. O ponto de chegada, ou, ao menos, o móvel dessa busca deveria ser uma simplicidade natural, ontológica, que dispensasse explicações, a que Bandeira anseia como seu testamento poético, conforme atesta-se por "O último poema", que fecha Libertinagem: 


\title{
O ÚLTIMO POEMA
}

\begin{abstract}
Assim eu quereria o meu último poema
Que fosse terno dizendo as coisas mais simples e menos intencionais

Que fosse ardente como um soluço sem lágrimas

Que tivesse a beleza das flores quase sem perfume

A pureza da chama em que se consomem os diamantes mais límpidos

A paixão dos suicidas que se matam sem explicação.
\end{abstract}

(BANDEIRA, 1993, p. 145)

Mesmo o retorno à forma fixa, a partir de Lira dos Cinqüent'anos (1940), dar-se-ia sob a condição de não se excluir do rol de possibilidades poéticas "Todas as palavras sobretudo os barbarismos universais / Todas as construções sobretudo as sntaxes de exceção / Todos os ritmos sobretudo os inumeráveis" (BANDEIRA, 1993, p. 129).

Para Arrigucci Jr (1992), há na poesia de Bandeira, orientada pela leitura de Blaise Cendrars, uma mistura de elementos profundamente líricos e, portanto, pessoais, e de elementos épicos, absorvidos das populações humildes em que se vê mergulhado o poeta e das quais, afinal, faz parte. Observa-se, dessa forma, uma lírica que, posta a serviço da coletividade, promove uma sublimação do cotidiano, dando voz a quem, em surdina, fora posto à margem do processo social. $\mathrm{O}$ insignificante, pela voz da poesia, passa a significar.

Mas, se é possível vislumbrar em Bandeira uma aproximação intencional entre o drama do poeta e o da coletividade humilde que o circunda, em Jorge Barbosa tem-se uma coincidência mesma das condições dramáticas; as angústias do poeta e da coletividade não se relacionam pela similaridade, somente, mas pela identidade. No poema "Povo", por exemplo, o drama pessoal é uma construção metonímica do drama coletivo; a instabilidade, jogo dialético entre "serenidade e inquietação" (MARIANO, 1991, p. 98) que aflige o indivíduo, consubstanciado no eu-lírico do poema, é o mesmo que opera "na insistente projecção / de muitas gerações..." (BARBOSA, 2002, p. 46).

O drama da insularidade, portanto, "nódulo fundador de uma estética" (SANTOS, 1989, p. 57), que funda a poética de Jorge Barbosa, não é um drama somente pessoal, como o de Bandeira, mas o drama de todo cabo-verdiano anônimo de então, às voltas com a emigração ou o trabalho forçado nas plantations de São Tomé e Príncipe. 
O poeta confunde-se com "o espírito de seu povo" (SANTILLI, 1985, p. 11), estabelecendo com ele uma irmandade anônima, como sugerem os versos de Jorge Barbosa: “Ó Cabo-Verdiano humilde / anónimo / — meu irmão!” (BARBOSA, 2002, p. 63)

Para Elsa Rodrigues dos Santos (1989, p. 59), mesmo antes da Claridade e de Arquipélago, palpita em Jorge Barbosa um sentimento de angústia diante da condição insular do cabo-verdiano, o qual, por vezes, aflora em versos ainda não libertos das amarras da forma (ou, diria o Bandeira de "Os sapos", das "fôrmas"), como no poema "O Pássaro fechado", que transcrevemos abaixo:

Eu trago dentro de mim um pássaro fechado...

Bate asas, — quer voar! —, em ânsias desmedidas.

Bem o sinto no peito, ardente, alucinado,

Num gigantesco arfar de ondas enfurecidas.

Bem sinto no meu peito a sua vida inquieta;

Do seu desejo de ir o anseio insatisfeito...

Eu sinto o drama seu de ter uma grilheta

Que o não deixa sair do fundo do meu peito!

Decorre o meu viver num desassossegado

Percurso, num febril, num doido tumultuar,

- Porque trago no peito um pássaro fechado,

Que não posso matar, que não posso soltar!...

Brava, Cabo Verde

(BARBOSA, 2002, p. 329) $)^{24}$

\footnotetext{
${ }^{24}$ Originalmente publicado em Seara Nova, No. 206, Lisboa, Março de 1930, p. 214.
} 
Como o fizera Bandeira, o caminho da liberação formal, para Jorge Barbosa, ocorreria pelo desrecalque progressivo da escrita, sobretudo pela flexibilização rítmica e pela busca de uma simplicidade natural capaz de conduzir, sem alardes altissonantes, à essencialidade poética. Uma simplicidade sem artificialismos, como se depreende do poema abaixo:

\section{SIMPLICIDADE}

Eu queria ser simples naturalmente

sem o propósito de ser simples.

(...)

Não teria ambições de posses e grandezas, ingenuamente:

Contentar-me-ia

com os insignificantes objectos que os pobres estimam

algum canivete com argola para pendurar no cinto

que bem me serviria para picar na palma da mão

o tabaco para o cachimbo.

Ou talvez quisesse um relógio barato

desses que vinham do Japão antes da guerra.

(...)

(BARBOSA, 2002, p. 154)

Para Hamilton, há em Jorge Barbosa uma concepção de simplicidade natural cuja referência imediata é Alberto Caeiro. Para o crítico, tanto no heterônimo de Pessoa quanto no eu-lírico do cabo-verdiano, o ser imiscua-se ao meio e às pessoas a sua volta, de onde emerge como portador de um discurso que, embora pessoal, construiu-se a partir de uma abstração das vozes coletivas, anônimas. E conclui:

Portanto, o sujeito poético identifica-se com e apodera-se da humanidade e do anonimato do cabo-verdiano pobre, e o discurso da humildade e da melancolia 
caracteriza o ideolecto de Jorge Barbosa. Este discurso da humildade gira em torno da simplicidade. E no poema 'Simplicidade' o sujeito poético proclama: 'Eu queria ser simples naturalmente / sem saber que existia a simplicidade'. (HAMILTON, 1984, p. 135-136).

A simplicidade não apenas enlaça o destino do poeta Jorge Barbosa ao dos caboverdianos comuns, anônimos e irmãos, mas fornece-lhe subsídios para uma poética que, mesmo particular em seu estilo, mostra-se eficiente na expressão de anseios coletivos dos ilhéus, como conclui Jaime de Figueiredo:

\begin{abstract}
Sua poesia caminhou no aprofundamento das virtualidades originais para uma forma pessoal, conjugando a sinceridade do tom e a economia expressiva. Os seus verso simples traduzem a comovida identificação com a humilde matéria ambiente e os apagados dramas da vida das ilhas perdidas no mar cuja projeção ambivalente caracteriza a sua temática. (1961, pp. XX-XXI)
\end{abstract}

A identificação, pois, entre o despojamento formal de Jorge Barbosa e a realidade que sua poesia busca retratar, reforça "a solidariedade do homem-poeta com a tragédia do destino comum.” (FIGUEIREDO, 1961, p. XXI).

\title{
5.1.3 Ocorrência em Birmingham e uma notícia de jornal
}

O procedimento de valer-se de formas lingüísticas essenciais aparentemente simples para a descroção de realidades sociais complexas não se limitaria, tematicamente, em Jorge Barbosa, às ilhas de Cabo Verde, como se vê no significativo “Ocorrência em Birmingham”, cujo cenário não é o Porto Grande do Mindelo ou os campos secos de São Nicolau, mas o deep south dos Estados Unidos. ${ }^{25}$

\section{OCORRÊNCIA EM BIRMINGHAM}

\section{John}

de Birmingham

\section{Alabama}

\footnotetext{
${ }^{25}$ Cabe lembrar que os Estados Unidos, como principal destino de emigração dos cabo-verdianos, sempre povoou o imaginário dos ilhéus, estando presente em grande número de poemas, contos e romances de Cabo Verde.
} 
USA

entrou na tabacaria.

Foi insultado

soqueado

expulso.

Na rua

o polícia

espancou

derrubou

cuspiu

prendeu o desordeiro.

Negro safado!

(BARBOSA, 2002, p. 316)

Impossível não perceber, na leitura desse poema, a onipresença, seja temática, seja estrutural, do "Poema tirado de uma notícia de jornal", publicado por Bandeira em Libertinagem:

POEMA TIRADO DE UMA NOTÍCIA DE JORNAL

João Gostoso era carregador de feira livre e morava no morro da

[Babilônia num barracão sem número.

Uma noite ele chegou no bar Vinte de Novembro

Bebeu

Cantou

Dançou

Depois se atirou na Lagoa Rodrigo de Freitas e morreu afogado.

(BANDEIRA, 1993, p. 136) 
Em ambos os casos, observa-se de imediato, desde os títulos, uma das características centrais do modernismo: a mescla de discursos, com nítido aproveitamento de textos originalmente não poéticos (ou mesmo antipoéticos) para a construção literária.

Os dois protagonistas passam, logo na primeira estrofe de cada poema, quando são apresentados, por uma espécie de Gênesis às avessas, no qual, ao invés de receberem com seus nomes a anima, o sopro vital, sofrem um processo de negação do 'ser' em função do modo genérico como são nomeados. João, personagem de Bandeira, possui um nome extremamente comum em língua portuguesa, sobretudo no Brasil; não possui sobrenome ou não nos é dado conhecê-lo; a alcunha, "Gostoso", que poderia defini-lo, ou, ao menos, torná-lo distinto dos demais, é algo acessório, adjetivo, incapaz de conferir-lhe, de fato, algo de essencial. Sua morada, como ele próprio, é algo impreciso, vago, indistinto, um barracão sem número. John, figura central no poema de Barbosa, possui apenas um primeiro nome, bastante comum em língua inglesa e incapaz, portanto, de conferir-lhe qualquer especificidade.

Há que se assinalar uma diferença significativa nos destinos (trágicos) de John e de João. João Gostoso, após o festim de que participa no bar Vinte de Novembro, no qual é agente, como expressam os verbos (“chegou”, “bebeu”, “cantou”, dançou”), experimenta um momento de epifania ao mergulhar de própria vontade na bem nomeada Lagoa Rodrigo de Freitas, de cujas águas, símbolo quase universal de (re)nascimento, emerge como alguém digno de figurar em uma notícia de jornal. John, por outro lado, ao romper a rígida delimitação de espaços entre brancos e negros no sul dos Estados Unidos, deixa de ser agente de si. O único verbo que tem John como sujeito ativo é justamente entrar, destacado na segunda estrofe, de apenas um verso. Nos dois blocos de ações do poema, tem-se, inicialmente, uma relação enxuta do que a ele acontece no interior da tabacaria, sempre na voz passiva: "Foi insultado / soqueado / expulso"; e, em seguida, já na rua, quando a voz ativa é empregada, transfere-se a ação para o policial, que o encaminha para a prisão. A voz que se revela em discurso indireto livre no último verso relativiza ou mesmo contradiz a neutralidade que se esperaria, em princípio, de um registro de ocorrência. Tudo se dá ou se justifica pelo fato de ser ele, John, um "negro safado", ou, desvelando-se a ideologia racista que se esconde sob a insuspeição do discurso indireto livre, "negro", logo, "safado". Paradoxalmente, após um processo intenso de negação de seu 'ser', John é responsabilizado justamente por algo que lhe é inerente, que pertence, enfim, ao seu ser. 
Diferentemente de João Gostoso, cuja história transcendente ganhou as páginas dos jornais, de onde Bandeira "tirou" o poema, John não tem outra voz senão a do próprio eu-lírico. Contudo, seu anonimato o aproxima, de certo modo, do destino comum de milhares de outros oprimidos cujas histórias também não ganharam as páginas dos jornais. Seus destinos trágicos enlaçam-se e, ao serem cantados pelo poeta, ganham uma voz audível, estejam eles em Birmingham, Alabama, nos vilarejos caboverdianos varridos pela lestada ou no brasileiro Morro da Babilônia. 


\subsection{Manuel Bandeira e Osvaldo Alcântara: poéticas do alumbramento}

Baltasar Lopes da Silva, Baltasar Lopes, Osvaldo Alcântara, nomes de que se valeu um mesmo autor ao assinar suas obras de filologia, ficção e poesia, respectivamente. Nasceu na ilha de São Nicolau, a 23 de abril de 1907. Após os estudos secundários, ingressou na Universidade de Lisboa, onde se formou em Direito e Filologia Românica. De volta ao arquipélago, trabalhou largos anos como professor liceal, sendo carinhosamente apelidado por alunos das diversas gerações que formou como Nhô Baltas. Faleceu na ilha de São Vicente, a 28 de maio de 1989.

Sua atuação como lingüista e filólogo desenvolveu-se desde a Claridade, onde publicou uma série de artigos sobre o idioma crioulo intitulada "Uma experiência românica nos trópicos". Em 1947, apresentou O dialecto crioulo de Cabo Verde, primeiro estudo minucioso sobre o idioma materno dos cabo-verdianos e até hoje um dos mais significativos.

Em 1947 publicou Chiquinho (1947), romance de formação (bildungsroman) em que esboça uma alegoria da geração da Claridade.

\subsubsection{Poética do alumbramento}

Em Humildade, Paixão e Morte, estudo fundamental da poesia de Manuel Bandeira, Davi Arrigucci Jr, em um dos ensaios que compõem o livro ("A Poesia em Trânsito: Revelação de uma Poética"), chama nossa atenção para a importância de se estudar, num trabalho de pesquisa e análise, o modo pelo qual um determinado autor concebeu a poesia ou, mais especificamente, o processo de sua elaboração, o "fazer poético" em si. Feita tal reflexão, o ensaísta se dispõe a seguir, quer pela análise dos poemas, quer pelas referências ao assunto que faz o próprio Bandeira em sua obra em prosa (sobretudo em Itinerário de Pasárgada, de 1954), o percurso poético por ele trilhado ao longo da formação de sua consciência artística.

A conclusão a que chega é que, para Bandeira, a inspiração artística, capaz de desencadear todo o processo de construção poética na literatura, se dá por uma espécie de iluminação instantânea (quase sobrenatural), uma percepção imediata de algo que parecia oculto e que, num lampejo, salta aos olhos ou à memória do poeta. Um 
alumbramento ditado pelo subconsciente, passível de ocorrer a qualquer hora, em qualquer lugar, e até mesmo em sonhos, como chegou a afirmar o próprio Bandeira.

Na minha experiência pessoal fui verificando que o meu esforço consciente só resultava em insatisfação, ao passo que o que me saía do subconsciente, numa espécie de transe ou alumbramento, tinha ao menos a virtude de me deixar aliviado de minhas angústias. (BANDEIRA, 1984, p. 30; grifo nosso)

Tal concepção, além do próprio sentido básico da palavra alumbramento, remonta, obviamente, ao caráter místico-religioso do Simbolismo (ou mesmo do Romantismo). Mas, em Bandeira, em função de seu percurso poético rumo ao Modernismo, assumirá o aspecto de uma "iluminação profana", na expressão cunhada por Walter Benjamin para designar a inspiração surrealista. Não coincidentemente, nos momentos em que Bandeira faz referência direta à questão, a revelação dar-se-á sobretudo pela descoberta do corpo feminino, ora como inusitada aparição em meio a brumosa evanescência simbolista ("Alumbramento", de Carnaval, 1919), ora inserida no conjunto de imagens que a memória lhe oferece ("Evocação do Recife", de Libertinagem, 1930).

Essa poética do alumbramento cumprirá um papel fundamental na construção de uma literatura fundamentada em bases legitimamente nacionais, pois funcionará como um mecanismo de registro de elementos da cultura popular, tomados de momentos humildes do cotidiano.

É certo que o simples fato de se lançar alguma luz sobre esses momentos não lhes assegura um status de obra poética. É preciso, num segundo momento, que se promova um trabalho de elaboração estética que possibilite o desentranhamento do sublime, que, para o poeta, oculta-se nas coisas mais chãs.

É que para o poeta, a revelação simbólica da poesia, a inspiração repentina, se dá no chão do mais 'humilde cotidiano', de onde o poético, como um $\underline{\text { sublime oculto, }}$ pode ser desentranhado, ou seja, re-velado, por força da depuração e condensação da linguagem, na forma simples e natural do poema. (ARRIGUCCI, 1992, pp.128-129; grifos do autor).

Já no começo do século XX, pouco antes, portanto, dos primeiros trabalhos poéticos de Bandeira, no ensaio "A arte como procedimento", Chklovski (apud TOLEDO, 1971) definira o trabalho do artista como um lento processo de singularização 
de momentos importantes, pinçados da massa global de fatos cotidianos. Jorge Luís Borges, em conferência recentemente publicada, trouxe a idéia para a esfera da palavra: "Claro, há duas maneiras de usar a poesia [...]. Uma das maneiras é o poeta usar as palavras comuns e de algum modo torná-las incomuns - extrair-lhes a mágica.” (2001, p. 26)

Esse trabalho de depuração e desrecalque da linguagem significará uma busca incessante das mais sintéticas e essenciais formas de expressão, capazes de evidenciar o humilde dentro do próprio humilde, o humílimo, o húmus, substância ordinária de tão simples, mas potencial, palpitante de vida, e, portanto, apta a fertilizar a nova literatura que ora se propunha.

O agrupamento desses pequenos quadros alumbrados do cotidiano, esteticamente organizados de modo a compor um mosaico representativo da cultura nacional, propiciaria o surgimento de uma nova forma de produção poética, responsável tanto por uma emancipação temática ante os padrões europeus quanto pela descoberta de uma nova estética, capaz de nos traduzir de modo original: "E ainda muito mais: $\underline{\text { o achado }}$ estético era também o achado de um país, pois equivale a um modo de tratar esteticamente uma visão do Brasil.” (ARRIGUCCI, 1992, p. 103; grifo do autor)

E, se o registro que se faz do país por meio dessa poética do alumbramento é, basicamente, fotográfico, pode-se considerar que o primeiro elemento apreendido será o espaço; porém, não mais em seu registro erudito, herdado de uma oficialidade burocraticamente constituída, mas em seu registro popular, o mais chão possível, de que Bandeira buscará extrair seu húmus, e no qual Osvaldo Alcântara e os demais claridosos buscarão fincar os pés, expressões semanticamente muito próximas.

Em suma, o registro ou a iluminação de quadros cotidianos por meio de uma 'poética do alumbramento' será fundamental para Bandeira e para os claridosos, empenhados em apreender um espírito popular de suas respectivas nacionalidades, a partir dos quais pudessem se firmar literaturas que não mais se pautassem por valores exclusivamente europeus.

\subsubsection{Do Alumbramento à Claridade}

Também interessados em trazer à luz pequenos quadros cotidianos capazes de construir em conjunto um amplo painel nacional, os autores cabo-verdianos da primeira 
fase da Claridade, com especial destaque para Osvaldo Alcântara, mostrar-se-ão sensíveis a essa poética do alumbramento. Ao comentar a influência de autores modernistas brasileiros na poesia de Cabo Verde, especialmente na dos claridosos, o autor (assinando Baltasar Lopes), assim se refere ao poema "Evocação do Recife": "Em poesia, foi um alumbramento a 'Evocação do Recife', de Manuel Bandeira, que, salvo um ou outro pormenor, eu visualizava, com as suas figuras dramáticas, na minha vila da Ribeira Brava.” (LOPES, 1956, pp. 5-6; grifo nosso).

Evidentemente, não se pode considerar aleatória, por parte do autor caboverdiano, a escolha específica desse poema e, nem tampouco, sua posterior classificação como um alumbramento. Em "Evocação do Recife" tem-se um exemplo claro de uma totalidade estética textual composta pelo agrupamento (aparentemente caótico, mas bastante organizado) de vários quadros cotidianos pinçados da memória, evocados e revistos pela visão alumbrada do eu-lírico. Quadros que esse mesmo eu-lírico classifica como "alumbramentos", como se percebe pelo seguinte trecho:

\section{Um dia eu vi uma moça nuinha no banho}

Fiquei parado o coração batendo

Ela se riu

Foi o meu primeiro alumbramento

(BANDEIRA, 1993, p. 135; grifo nosso)

Trata-se, aqui, de um admirável caso de intratextualidade, pois Bandeira recapitula textualmente um episódio que já lhe servira de mote para a composição de outro poema, não por acaso intitulado "Alumbramento", inserido no livro Carnaval.

A idéia de luminosidade ou de iluminação embutida na palavra alumbramento adequa-se a uma das principais tarefas chamadas para si pelos claridosos: um serviço de guia, de orientação à nova literatura que, a partir do trabalho do grupo, poderia surgir no arquipélago. Idéia expressa já pelo próprio nome escolhido para o órgão de divulgação do grupo: Claridade.

Em diversas obras dos claridosos temos exemplos de sua afinidade com esse trabalho de orientação ou de iluminação, não apenas da literatura, mas, por vezes, dos 
rumos do próprio país. No conto "Galo cantou na baía”, de Manuel Lopes, inicialmente publicado no segundo número da revista e, como se sabe, uma alegoria do próprio movimento claridoso, várias são as referências simbólicas a esse respeito, como a recorrente menção ao farol do Ilhéu dos Pássaros ou a possante voz do comandante do barco de cabotagem conclamando os remadores a colocarem-no nos rumos: "Remos n’água! Falucho anda sem governo. Remos n'água!".

Se imaginarmos a 'poética do alumbramento' como um procedimento técnico de captação e registro de imagens por meio da literatura, perceberemos que ela se assemelha, em muitos aspectos, à própria fotografia, que então se popularizava, à época de Libertinagem, Estrela da Manhã e Claridade, com o surgimento das primeiras câmeras portáteis. Vários são os autores desse período que utilizaram imagens ligadas à fotografia (ou ao nascente cinema, por extensão) em suas obras, como Antônio de Alcântara Machado (Pathé Baby) e Blaise Cendrars (Kodak). E também os caboverdianos. Em carta a Jorge Barbosa, Manuel Lopes compara certos poemas do autor de Arquipélago a "chapas fotográficas" (apud SANTOS, 1989), a retratar não só o espaço físico de Cabo Verde, mas toda a alma de um povo.

Esse novo enfoque sobre a própria nacionalidade foi fundamental para que se pudesse consolidar uma literatura diversa da que até então havia no arquipélago. Mais do que uma abertura para novas possibilidades estéticas, significou o início de um processo que transformaria os artistas em agentes de sua própria condição, de passivos a ativos, de pessoas que apenas são vistas a pessoas que vêem. A "visão alumbrada" (ARRIGUCCI, 1992, p.139) transcende o mero efeito provocado por uma imagem ou por uma lembrança, induzindo a uma resposta produtiva diante da impressão inicial recebida, já que, após o breve instante de êxtase, elabora e emite sua própria voz, capaz, por seu turno, de desencadear novos alumbramentos.

\subsection{3 "Evocação do Recife" $e$ "A Serenata"}

Para observar mais de perto os procedimentos literários desencadeados pela poética do alumbramento, escolhemos os poemas "Evocação do Recife", de Manuel Bandeira, e "Serenata”, de Osvaldo Alcântara, os quais transcrevemos, integralmente, abaixo: 


\section{EVOCAÇÃO DO RECIFE ${ }^{26}$}

01 Recife

02 Não a Veneza americana

03 Não a Mauritssatd dos armadores das índias Ocidentais

04 Não o Recife dos Mascates

05 Nem mesmo o Recife que aprendi a amar depois -

$06 \quad$ Recife das revoluções libertárias

07 Mas o Recife sem história nem literatura

08 Recife sem mais nada

09 Recife da minha infância

10 A Rua da União onde eu brincava de chicote-queimado e partia as vidraças

[da casa de Dona Aninha Viegas

11 Totônio Rodrigues era muito velho e botava o pincenê na ponta do nariz

12 Depois do jantar as famílias tomavam a calçada com cadeiras, mexericos,

[namoros, risadas

13 A gente brincava no meio da rua

14 Os meninos gritavam:

$15 \quad$ Coelho sai!

$16 \quad$ Não sai!

17 A distância as vozes macias das meninas politonavam:

$18 \quad$ Roseira dá-me uma rosa

19 Craveiro dá-me um botão

$20 \quad$ (Dessas rosas muita rosa

21 Terá morrido em botão...)

\footnotetext{
${ }^{26}$ Por praticidade nas citações, optamos por numerar os versos dos poemas.
} 
22 De repente

23 nos longes da noite

24

um sino

25 Uma pessoa grande dizia:

26 Fogo em Santo António!

27 Outra contrariava: São José!

28 Totônio Rodrigues achava sempre que era São José.

29 Os homens punham o chapéu saíam fumando

30 E eu tinha raiva de ser menino porque não podia ir ver o fogo

31 Rua da União...

32 Como eram lindos os nomes das ruas da minha infância

33 Rua do Sol

34 (Tenho medo que hoje se chame do Dr. Fulano de Tal)

35 Atrás de casa ficava a Rua da Saudade...

36

... onde se ia fumar escondido

37 Do lado de lá era o cais da Rua da Aurora...

... onde se ia pescar escondido

39 Capiberibe

40 - Capibaribe

41 Lá longe o sertãozinho de Caxangá

42 Banheiros de palha

43 Um dia eu vi uma moça nuinha no banho

44 Fiquei parado o coração batendo

45 Ela se riu

46

Foi o meu primeiro alumbramento

47 Cheia! As cheias! Barro boi morto árvores destroços redomoinho sumiu 48 E nos pegões da ponte do trem de ferro os caboclos destemidos em jangadas

[de bananeiras 
49 Novenas

50

\section{Cavalhadas}

51 Eu me deitei no colo da menina e ela começou a passar a mão nos meus

[cabelos

52 Capiberibe

53 - Capibaribe

54 Rua da União onde todas as tardes passava a preta das bananas com o xale

[vistoso de pano da Costa

55 E o vendedor de roletes de cana

56 O de amendoim

$57 \quad$ que se chamava midubim e não era torrado era cozido

58 Me lembro de todos os pregões:

59 Ovos frescos e baratos

60 Dez ovos por uma pataca

61 Foi há muito tempo...

62 A vida não me chegava pêlos jornais nem pelos livros

63 Vinha da boca do povo na língua errada do povo

64 Lingua certa do povo

65 Porque ele é que fala gostoso o português do Brasil

66 Ao passo que nós

$67 \quad$ O que fazemos

68 É macaquear

69 A sintaxe lusíada

70 A vida com uma porção de coisas que eu não entendia bem

71 Terras que não sabia onde ficavam

72 Recife...

73 Rua da União...

74 A casa de meu avô...

75 Nunca pensei que ela acabasse!

76 Tudo lá parecia impregnado de eternidade 
77 Recife...

78

Meu avô morto.

79 Recife morto, Recife bom, Recife brasileiro como a casa de meu avô

Rio, 1925.

(BANDEIRA, 1993, pp. 133-136)

\section{A SERENATA}

01 Vestida de gemidos de bordão,

02 lancinâncias de violino

03 na noite parada

04 vem descendo a serenata.

05 Sumiu-se a cidade barulhenta

06 inimiga das crianças e dos poetas.

07 Uma voz canta sentimentalmente um samba.

$08 \quad$ Aquele aperto de mão

09 não foi adeus!

10 Os cavaquinhos desmaiam de puro sentimento,

11 a cidade morreu lá longe,

12 e a lua vem surgindo cor de prata.

13 Nessa história de amor todos são iguais,

14 até rei volta sua palavra atrás...

15 O meio-tom brasileiro deixa interrogativamente a sua nostalgia ...

$16 \quad$ É a hora que os poetas escolheram

17 para a procura dos seus mundos perdidos...

18 Amanhã a cidade virá novamente 
19 Inimiga dos poetas.

20 Mas agora ela dorme,

21 ela não sabe que os poetas falam com Nossenhor,

22 com a lua e as estrelas,

23 nesta hora tão lírica...

24 Menina romântica, Irmã

25 das crianças e dos poetas...

26 A tua janela, florida de esperanças,

27 é um mistério que a cidade não entende.

28 Passa a serenata.

29 Mas no coração dos que temem a primeira luz do dia que vai chegar

30 ficam os gemidos do violão e do cavaquinho,

31 vozes crioulas neste nocturno brasileiro

32 de Cabo Verde.

(Claridade, No. 6, p. 21)

Em "Evocação do Recife", pode-se observar uma composição organizada a partir de pequenos quadros cotidianos que, em conjunto e alumbrados pelo olhar diferenciado que o eu-lírico lhes destina, fornecem a matéria-prima de que se compõe o poema.

O poema de Osvaldo Alcântara nos lembra, em muito, o de Bandeira. Tem-se também a construção de um todo a partir de breves cenas cotidianas, aparentemente caóticas, sem vínculos precisos, mas que, em conjunto, tornam-se coerentes pela organização que lhes confere o eu-lírico, valendo-se de sua visão também alumbrada. A declaração do próprio Baltasar Lopes, que já citamos, de que "Evocação do Recife" teria sido um alumbramento para ele e seus pares, não deixa qualquer dúvida quanto ao impacto que o poema teria causado no arquipélago quando por lá aportou, nos anos de 1930, quando se maturavam as idéias e os anseios que culminariam com a publicação da revista Claridade. 
Gabriel Mariano (1991, p. 169) vê não apenas em "Serenata", mas em todos os "Quatro poemas do ciclo da vizinha" 27 , um procedimento de elaboração estética que procura, partindo do pormenor, atingir o universal, procedimento esse que, em linhas gerais, pode ser considerado como uma suma do ideário inicial da Claridade, com seu objetivo manifesto de mergulhar nos valores legitimamente cabo-verdianos de cultura ("fincar os pés em Cabo Verde", como diziam), a partir dos quais descobririam sua maneira originam de inserção no mundo.

Tanto em "Evocação do Recife" quanto em "Serenata”, tem-se várias seqüências de registros de cenas cotidianas, tomadas quase ao acaso, em registro minucioso. $\mathrm{O}$ fluxo contínuo dessas imagens registradas cuida para que tenham dinamicidade, movimento. E os quadros, encadeados, assemelham-se a tomadas não mais fotográficas, mas cinematográficas. Não por acaso, os primeiros filmes rodados surpreendiam justamente por serem capazes de captar o cotidiano das pessoas e dos lugares, como também o fazem Bandeira e Osvaldo Alcântara. ${ }^{28}$

Ora, se o que a objetiva poética dos autores capta é um cenário popular, uma cidade não só alheia, mas principalmente avessa ao formalismo burocrático da oficialidade, será comum o flagrante de personagens típicas desse ambiente, revestidas de uma aura de humildade e ternura que muito as aproxima do eu-poético, desejoso de relações dessa natureza.

Mas não se trata apenas de uma questão temática ou e uma preferência fortuita por determinados grupos sociais. Ao utilizarem tais figuras, um Totônio Rodrigues, um Tói Mulato, nomeadas informalmente, os autores evidenciam sua opção por um registro de linguagem também popular, muito próxima do coloquial. Exemplo determinante desse fato são as transcrições, em discurso direto, das falas dessas personagens, sobretudo em forma de letras de canções ou trovas populares. Tanto em Bandeira quanto em Alcântara, é comum o destaque de tais falas, em geral mais recuadas da margem esquerda que os demais versos. Além disso, pinçadas pela memória exatamente no momento de suas respectivas manifestações, essas vozes populares trarão em si elementos estéticos distintos da própria voz do eu-lírico, como a métrica em redondilhas, ao invés do verso livre comumente adotado.

\footnotetext{
${ }^{27}$ São eles: I - Canção da minha rua; II - Aqui d'el Rei; III - Tonico na ronda infantil; e IV - A Serenata. (Claridade, №. 6, p. 21).

${ }^{28}$ Os próprios irmãos Lumière realizaram filmes dessa natureza, registrando a chegada de um trem à estação, a saída de uma fábrica, um jardineiro desastrado que se molha ao regar as plantas etc.
} 


\subsubsection{Futuro do pretérito}

Em ambos os poemas, observa-se a busca por uma condição outra, seja espacialmente, evocando-se um Recife de outrora, no caso e Bandeira, ou a cidade noturna em que se movem os músicos da serenata, no caso de Osvaldo Alcântara, seja temporalmente, projetando-se no futuro uma condição anterior mais desejável e mais desejada que a atual, procedimento utópico sobre o qual nos detivemos no Capítulo 4.

Tanto em Bandeira quanto nos claridosos essa projeção mostrar-se-á um eficiente instrumento contra-ideológico, comum nas poéticas da modernidade, que aproveitaram, com esse intuito, a capacidade antecipadora das narrativas utópicas ${ }^{29}$, nas quais vislumbraram uma possibilidade de superação da condição presente.

Observa-se, contudo, nos países de colonização portuguesa, um paradoxo que não se desvenda senão por uma visão dialética da cultura. A constante atualização utópica que permeia toda a cultura portuguesa (e de que o sebastianismo é um claro exemplo), ânsia quase incontrolável de se projetar no futuro uma condição tão gloriosa quanto à do passado, encontrará guarida no seio das próprias culturas colonizadas, que utilizarão o artifício contra o aparato colonizador. Mesmo em Cabo Verde, não habitado antes da chegada dos portugueses, há a projeção de um referencial de espaço mítico, um mundo anterior ao do colonialismo e que, vez por outra, presentifica-se no continente fictício de Atlântida, cujo nome cogitou-se de ser também o da própria revista Claridade.

O novo espaço, em que se sobrepõem passado e futuro, rompe com a linearidade do tempo e, em consequiência, com as estruturas estagnárias, quer no âmbito da dominação colonial, quer na literatura.

A poesia de Bandeira, bem como a dos claridosos, encarregou-se, junto a outros fatores, de minar tais estruturas, funcionando como um instrumento contra-ideológico. Motivo que, somado aos fatores de ordem estética, permitiu que suas respectivas obras se perpetuassem pelas gerações seguintes, consolidando os sistemas literários de cada um dos países. 


\subsubsection{Da evocação inconsciente ao exercício poético}

Em O Ser e o Tempo da Poesia, Alfredo Bosi inclui, dentre as faculdades de que seriam dotados os poetas, a de nomear, isto é, a capacidade de exercer uma substantivação primordial (ainda que abstrata) dos seres ao traduzi-los por meio da linguagem poética. Parece-nos, pois, pertinente iniciarmos esta breve análise tecendo considerações acerca dos títulos que Bandeira e Osvaldo Alcântara escolheram, respectivamente, para cada um dos dois poemas.

O poema de Bandeira tem, inegavelmente, como mola propulsora, a memória, mas não enquanto um raciocínio consciente e medido acerca do passado. Trata-se de um rememorar espontâneo que, encontrando adequada vazão na personalidade poética do autor, transborda para o presente numa espécie de fluxo contínuo, quase incontrolável, de elementos que, pelo texto, presentificam-se: uma evocação do passado, e não uma reflexão racional sobre ele.

Inegavelmente, evocar é um exercício espontâneo de memória, um manancial de matéria-prima poética ditado pelo inconsciente a partir do que fora vivido pelo poeta em sua infância. Mas não só isso. Da grande massa de informações, cuidará o poeta de fazer os recortes e os agrupamentos necessários para que se tenha um todo coerente, capaz de atingir o leitor, seja pelo conteúdo nele embutido, seja pela construção estética em si.

Há, pois, um duplo movimento, inicialmente espontâneo, mas logo controlado pelo trabalho de seleção, recorte e montagem do poeta. Processo bastante semelhante ao que Barthes chamou de "procedimentos de conotação" (1985, p. 243) ao analisar a mensagem fotográfica.

Assim, "Evocação do Recife" é um poema composto a partir de uma memória espontânea, mas com participação do poeta, que fornece a substância de memória a ser recortada e, mais, seleciona e encadeia os quadros. Um lembrar espontâneo sim, mas não totalmente passivo, como se uma espécie de voz medial ${ }^{30}$, misto de ativa e passiva. Essa voz intermédia utilizada por Bandeira na construção do poema mostra-se capaz de conciliar dois aspectos aparentemente paradoxais desse fluido de memória, dessa evocação de uma época e de um lugar distantes levada a cabo pelo eu-lírico. Se, por um

\footnotetext{
${ }^{29}$ Sobre essa capacidade antecipadora, profética da narrativa utópica, ver CIONARESCU, 1972. p. 40.

${ }^{30}$ Para Mattoso Câmara (1992, p.164), a voz medial, em português, nada mais seria do que uma voz ativa que se aproxima da passiva pela junção do pronome átono, referente ao próprio sujeito.
} 
lado, não confere à memória um aspecto burocrático, patriotesco, que o autor não deseja e até repudia, impede que o substancioso material que espontaneamente assoma ao seu pensamento lhe escape das mãos.

Não seria conveniente, portanto, pensar-se numa espontaneidade absoluta, numa desvinculação total de qualquer parâmetro estético-literário pré-estabelecido se se trata de um autor que, como Bandeira, sempre se fez notório pelo profundo conhecimento do ofício da lírica, quer como o teórico de De Poetas e de Poesia (1954) ou de "Versificação em Língua Portuguesa" (1956), quer como o poeta maduro de Libertinagem e Estrela da Manhã?

Não nos parece possível encontrar uma resposta meramente conciliadora, uma vez que o profundo conhecimento da tradição lírica em língua portuguesa adquirida, pensada e trabalhada por Bandeira nas primeiras décadas do século XX foi fundamental para a arquitetura do lirismo libertário de Libertinagem, admiravelmente sintetizado no poema "Poética", contraponto modernista à "Profissão de Fé" de Bilac.

É pertinente que se faça, então, uma leitura dialética da poesia de Bandeira e, para tanto, julgamos conveniente a aplicação do conceito de "poesia como resistência", desenvolvido por Alfredo Bosi a partir de sua obra supra citada e retomado sinteticamente anos mais tarde, quando diria que "a poesia não é liso espelho da ideologia dominante, mas pode ser o seu avesso e contraponto” (BOSI, 1996, p. 37).

Se o que se pretende é erigir um novo espaço, que, em meio a outros elementos, funcione como uma resistência à ideologia dominante, cabe, como tarefa inicial, desconstruir o anterior, para que a sobreposição não venha a prejudicar a visão do leitor. É o que faz Bandeira na primeira estrofe, quando, após reafirmar no primeiro verso o assunto sobre o qual discorrerá durante todo o poema, a cidade do Recife, cuida por especificar de que cidade se trata, isto é, a que lhe vem inconscientemente pela memória, e não a que fora construída de modo burocrático pelo poder constituído. Bandeira esquiva-se inicialmente da cidade que se designa a partir de parâmetros exteriores (Não a Veneza americana / Não a Mauritssatd dos armadores das ìndias Ocidentais); depois, em gradação, da que lhe chegou pela história oficial (Não o Recife dos Mascates); finalmente, explicita o Recife de que tratará no poema, livre de qualquer recalque, o "Recife sem história nem literatura / Recife sem mais nada / Recife da minha infância”. 


\subsubsection{U-topos: negar o espaço para reconstruí-lo}

Antes mesmo de nos atermos ao título escolhido pelo cabo-verdiano para seu poema, vemos que a subdivisão em que ele se encaixa já cuida por instaurar, antes de sua leitura, uma ambientação cujos parâmetros de valor não são eruditos, mas plenamente populares: "Quatro poemas do ciclo da vizinha". Impossível não pensar, aqui, numa espécie de intimidade cotidiana, responsável pela inserção natural do eulírico no espaço, exatamente como já o fizera Bandeira, e de que o verso 12 ("Depois do jantar as famílias tomavam a calçada com cadeiras, mexericos, namoros, risadas”) é um claro exemplo.

Dessa intimidade popular, Osvaldo Alcântara recortará, pela escolha do tema, já indicado no título, um espaço e um momento precisos: a rua e a noite. A serenata, na música popular $^{31}$, é uma manifestação em geral amadora, que se desenvolve após o pôrdo-sol e sempre a céu aberto, isto é, distante dos salões ou salas de concerto.

Tem-se, portanto, um tema tomado à musicalidade, tipicamente cabo-verdiana e, no poema, com recorrentes elementos brasileiros. Mistura de que se tem um resumo nos versos 07, 15 e 31-32. Também em sua prosa, o autor, que então se vale de seu próprio nome, Baltasar Lopes, já o fizera. No romance Chiquinho, sobressai, dentre os demais (em espaço e importância), o capítulo em que se descreve um baile de carnaval, tem-se um microcosmo da cultura cabo-verdiana da cidade do Mindelo, que se entremostra a partir da musicalidade, e em que também se faz presente a música brasileira; e a mesma associação seria feita, no futuro, em "Carnaval de São Vicente", espécie de samba estilizado, composto por Pedro Rodrigues ao estilo das trilhas do teatro de revista brasileiro e dos filmes da Atlântida. ${ }^{32}$

Após o verso 07, "Uma voz canta sentimentalmente um samba”, o autor introduz uma série de ecos de letras de sambas, como se a voz ou (por que não?) as vozes brasileiras que os cantassem invadissem o próprio eu-lírico, numa espécie de discurso indireto livre, adequado à continuidade do fluxo de imagens de que se compõe o texto. O eco imediato, isto é, desenvolvido nos dois versos seguinte ("Aquele aperto de mão / Não foi adeus!'), encontra-se destacado da margem esquerda, exatamente como

\footnotetext{
${ }^{31}$ Utiliza-se o termo também na música erudita, mas numa acepção diversa.

${ }^{32}$ Gravado por Cesária Évora em Café Atlântico, RCA/Lusáfrica, 1999.
} 
faz Bandeira quando transcreve letras de cantigas ou pregões populares em "Evocação do Recife" (versos 15-16, 18-21 e 59-60). Após o que seria uma espécie de improviso instrumental, em que "Os cavaquinhos desmaiam de puro sentimento", coerente com a voz que, sentimentalmente cantava um samba, o eco de uma marchinha de Lamartine Babo e Braguinha, já aproveitada por Bandeira na bricolagem poética que faz em "Balada das três mulheres do sabonete Araxá", poema publicado em Estrela da Manhã. Trata-se do verso 12 de "Serenata" ("e a lua vem surgindo cor de prata"), mais próximo do que a forma utilizada por Bandeira ("Mulatas cor da lua vêm surgindo cor de prata”). ${ }^{33}$ E, por fim, o último eco que se ouve, nos versos 13 e 14 , "Nessa história de amor todos são iguais / Até rei volta sua palavra atrás...”, trechos de um samba de Jair do Cavaco, que se tornariam bordões carnavalescos nos salões cariocas.

O rastro deixado pela incursão da musicalidade brasileira no texto contribui decisivamente para o reforço da idéia de imprecisão já sugerida pelo próprio título do poema.

Como em "Evocação do Recife", o intento de criar um novo espaço exigiu que o eu-lírico de "Serenata" fizesse referências explícitas a uma aversão à cidade oficial, identificada com o dia, por oposição à serenata, opressora das crianças e dos poetas, como se depreende dos versos "Sumiu-se a cidade barulhenta / inimiga das crianças $e$ dos poetas" e "Amanhã a cidade virá novamente / inimiga dos poetas".

Como se vê, Bandeira e Osvaldo Alcântara buscaram, antes de mais nada, um espaço utópico, no sentido quase literal do termo, uma negação do anterior, um nãolugar, u-topos. Cionarescu (1972), em um de seus trabalhos sobre o pensamento utópico na literatura, lembra-nos que o termo com o qual Thomas Morus designara sua ilha imaginária foi, provavelmente, forjado em conjunto com Erasmo. Em correspondência, Morus refere-se vez por outra a Nusquama Nostra, 'nosso país de nenhum lugar', espaço construído a partir do existente, mas isento de tudo o que lhe pudesse depreciar, numa espécie de "espelho contra-ideológico", utilizando-se a expressão de Alfredo Bosi.

A expressão é cabível, pois também Bandeira e Osvaldo Alcântara construirão o novo espaço que desejam (ou procurarão enxergá-lo) a partir de elementos do antigo, que, pelo trabalho lingüístico, desconstruíram em seus poemas.

\footnotetext{
${ }^{33}$ O samba, intitulado "Lua cor de prata", é de 1931. Sobre o referido poema de Bandeira, ver o ensaio de Sônia Brayner em LOPEZ, 1987, pp. 42-47.
} 
Não se trata, portanto, de erigir um novo espaço, mas de enxergar no de sempre, o que então se ocultava, ou encontrava-se desfocado por se ter um único e exclusivo ponto de vista, construído a partir de parâmetros europeus. 


\subsection{Manuel Bandeira e Manuel Lopes: lições de partir}

“(Todas as manhãs o aeroporto em frente me dá lições de partir. )"

(Manuel Bandeira)

"flutua ainda o perfil dum vapor que não me quis levar"

(Manuel Lopes)

Dos três principais autores da primeira fase da Claridade, Manuel Lopes é o que se mostra menos tributário da poética de Bandeira, talvez por demonstrar, desde cedo, uma propensão muito maior à prosa do que à poesia. Natural da ilha de São Vicente (1907), Manuel António dos Santos Lopes emigrou com sua família para Coimbra em 1919, onde viveu até 1923, retornando então a Cabo Verde como funcionário de uma companhia inglesa de telégrafos. Em 1944, foi transferido para os Açores, mudando-se de lá para Lisboa em 1959, onde residiu até seu falecimento em 2005.

Notabilizou-se sobretudo por sua obra em prosa, tendo publicado, já no segundo número da Claridade, a primeira versão do conto "Galo cantou na baía", o qual, pelo tratamento crítico dispensado aos temas sociais, antecipa-se ao neo-realismo português e deixa entrever suas afinidades com o ciclo dos romances nordestinos brasileiros. Afinidades essas que atingiriam o auge com seu mais conhecido romance, $O s$ Flagelados do Vento Leste, em que se descreve a luta dos cabo-verdianos contra as secas e contra as estruturas sociais de opressão que empurram os ilhéus para a morte ou para o exílio.

Em sua poesia, no entanto, o retrato crítico da realidade social cabo-verdiana, embora seja feito, não é revelado de modo tão evidente ou imediato. Ao assumir, predominantemente, o ponto de vista de quem, a despeito das vicissitudes e da vontade de partir, permaneceu no arquipélago, Manuel Lopes reveste sua poesia de um tom melancólico e intimista que a prende, em certa medida, ao Decadentismo que a precede.

O sentimento de frustração decorrente da permanência forçada nas ilhas só se apascenta quando a imaginação e o sonho encarregam-se de realizar a viagem refreada pelas contingências do real. Tal viagem, de natureza intelectual, é o fundamento, para Ferreira (1986), do evasionismo característico dos claridosos, os quais projetam-se no mundo além-arquipélago pelo artifício da escrita. 


\subsubsection{Do cisne de veludo...}

Em 1949, treze anos após o surgimento da Claridade, Manuel Lopes publicou nos Açores Poemas de quem ficou, coletânea que reuniu, a um tempo, trabalhos produzidos em épocas distintas, o que se verifica pela profunda diferença estética que há entre as duas partes de que se compõe o livro: "Momentos", datada de 1935, isto é, anterior à Claridade, e "Partir", datada de 1946.

Longe de diminuir o interesse que se possa ter pela coletânea, a presença de poemas concebidos a partir de preceitos tão diversos constitui uma oportunidade rara de se vislumbrar com maior nitidez o processo de transformação estética levado a cabo por Manuel Lopes, especificamente, e pelos demais claridosos, de um modo geral.

Os poemas da primeira parte do livro lembram, em grande medida, os da "geração da ambigüidade" (FERREIRA, 1986, p. XLV), cuja poesia aproxima-se dos preceitos estéticos parnasianos. Não fosse o subtítulo que acompanha os poemas, "Cabo Verde", dificilmente poderiam ser atribuídos a um autor cabo-verdiano. Não se encontram nesses versos iniciais, retratos da realidade das ilhas crioulas, como a labuta portuária ou o ciclo trágico das secas. Canta-se a "lua lívida", o "cisne de veludo".

Aos temas finisseculares, mesclam-se características formais semelhanças às do penumbrismo brasileiro, como a presença de versos polimétricos, a exemplo do Bandeira de A Cinza das Horas ou de Ribeiro Couto, a quem é dedicado um poema. Mas, mesmo variando o número de sílabas por verso, passo importante na flexibilização rítmica que levaria ao verso livre, Manuel Lopes o faz dentro dos preceitos canônicos, alternando decassílabos heróicos, com acentos tônicos que recaem sobre a segunda, sexta e décima sílabas, e versos dodecassílabos ao gosto parnasiano, com a esperada cesura na sexta sílaba. Vejam-se, como exemplo, três versos do poema "Rei":

Mas era desses sonhos que eu sonhava

_ Sem tal pureza de imaginação _

_ no momento em que o sol // morria brando e brando _

(LOPES, 1949, pp. 19 e 22) 
Por vezes, ao esboçar o tema da partida, característico da segunda parte do livro, Manuel Lopes deixa entrever flexibilizações da métrica, como na quadra abaixo, tomado do poema "Historieta". O segundo verso, com suas oito sílabas poéticas, quebra ritmicamente a quadra composta em decassílabos, em um procedimento característico, como já vimos, da fase penumbrista de Bandeira:

\author{
E quando me senti mais deus ainda \\ que o vago deus de toda gente, \\ _ pois era eu teu deus inteiramente, _ \\ fechei os olhos e sonhei distâncias...
}

(LOPES, 1949, p. 26)

\title{
5.3.2 ... ao cais de ver partir
}

Cientes da necessidade de conjugarem suas obras a teorias que lhes dessem sustentação, os claridosos reservaram em sua revista o devido espaço para artigos de natureza ensaística. Numa dessas seções, Manuel Lopes atenta-nos para a idéia de que um dos objetivos buscados era justamente uma nova visão do país, a partir de pontos de vista próprios. Tais artigos, presentes sobretudo na primeira fase de Claridade, ainda na década de 1930, receberam, não por acaso, o título de "Tomada de vista". Neles, Manuel Lopes, ao mesmo tempo em que repudia a visão exterior, sedenta de exotismo, busca traçar um perfil do cabo-verdiano como alguém dialeticamente dividido o 'querer partir e ter que ficar' e o 'querer ficar e ter que partir', idéias que o orientaram na segunda parte de Poemas de quem ficou, "Partir", na qual se percebe a adesão de sua poética ao "quere bipartido" do cabo-verdiano.

A simples observação dos títulos dos poemas que compõem cada uma das duas partes do livro já evidencia as diferentes concepções que orientaram, em cada caso, a escrita poética de Manuel Lopes. Em "Momentos", predominam títulos construídos a partir de substantivos abstratos isolados ou em expressões nominais: "Dispersão", "O Canto do Cisne", "Alucinação", "Desencanto", "Dança”, "Consummatum", "Isolamento", “Amor...”, "Libertação”, "Experiência”, "Ignorância”. 
Em "Partir", por sua vez, o ambiente difuso e abstrato dá lugar a imagens palpáveis, com o predomínio, nos títulos, de substantivos concretos, muitos dos quais, apontando para elementos típicos da realidade cabo-verdiana: "Navio", "Écran", "Cais", "Pescadores de Santo Antão", “Terra”.

Para Hamilton (1984, p. 123), contudo, há na poesia de Manuel Lopes, mesmo na que fora composta após a Claridade, um distanciamento entre a postura evasionista assumida pelo eu-lírico e os problemas concretos dos cabo-verdianos, como as secas e as fomes cíclicas (ou crônicas?) que assolavam constantemente as ilhas. Tal distanciamento seria decorrente do fato de Lopes conceber a problemática social caboverdiana como fruto das condições naturais desfavoráveis e do provincianismo engendrado pela insularidade, mais do que da condição colonial opressiva em que se via mergulhado o arquipélago.

Mais do que uma opção dentre outras, a saída do arquipélago, reforçada pelo apelo constante feito pelo mar e pelos navios, que também se vão, parece inevitável, embora nem sempre se realize, decorrendo, da permanência, um sentimento de frustração que se busca compensar pelo exercício poético. Como o aeroporto de Bandeira, o Porto Grande do Mindelo dá suas lições de partir, embora o que se veja continue sendo o beco ou "o perfil dum vapor que não me quis levar".

Jul'Antone, personagem do conto "Galo cantou na baía", representante dessa vida cabo-verdiana presa ao mar e a suas determinações, dá-nos seu testemunho a esse respeito: "Fujo. Todo o caminho era bom. Para o norte ou para o sul, para leste ou para oeste, todo o caminho era bom. Contanto que fosse caminho de mar, caminho longe. Porque isto aqui já dera o que tinha que dar." (LOPES, 1984, p. 18)

O protagonista do conto é, pois, um representante da cultura ligada ao mar e ao apelo de partir que dele parece provir cotidianamente. Ou, mais do que um mero exemplar dos habitantes que buscam seu sustento à roda do porto grande do Mindelo, esquiva-se da vida cabo-verdiana ligada à terra, à vocação para o trabalho agrícola.

Se fizemos essa breve incursão por um trabalho em prosa, gênero em que Manuel Lopes encontrou o melhor de sua expressão, foi para evidenciar o ambiente de desalento e expectativa de superação da realidade, ainda que pela poesia, no processo de "tomada de vista" ou de "posição", apregoada no artigo que mencionamos acima e que determina a mudança de tom entre as duas partes de que se compõe Poemas de quem ficou. A leitura do poema que dá nome ao livro fala por si só: 
POEMA DE QUEM FICOU

Eu não te quero mal

por este orgulho que tu trazes ;

Por este ar de triunfo iluminado

com que voltas...

. . . O mundo não é maior

que a pupila dos teus olhos:

tem a grandeza

da tua inquietação e das tuas revoltas.

.. . Que teu irmão que ficou

sonhou coisas maiores ainda,

mais belas que aquelas que conheceste...

Crispou as mãos à beira-do-mar

e teve saudades estranhas, de terras estranhas,

com bosques, com rios, com outras montanhas,

-bosques de névoa, rios de prata, montanhas de oiro -

que nunca viram teus olhos

no mundo que percorreste...

(Claridade, $\mathrm{N}^{\circ} .3$, p. 1) 
CONSIDERAÇÕES FINAIS 
Se falamos, aqui, em considerações finais, talvez o façamos somente por uma convenção formal. Desde o início de nossos trabalhos, percebemos não apenas a amplitude, mas a profundidade das relações existentes entre a poesia de Bandeira e de outros autores do modernismo brasileiro e a moderna literatura cabo-verdiana, que esboça seus primeiros passos com o grupo ligado à revista Claridade. Percebemos ainda, pela escassa bibliografia existente, que um substancioso corpus para pesquisa espera ainda a atenção de estudiosos que se disponham a analisá-lo.

A contribuição maior de nosso trabalho e de outros que igualmente se debruçam sobre o estudo das relações existente entre a literatura brasileira e as dos demais países de língua portuguesa, sobretudo africanos, é contribuir com o fortalecimento dos laços culturais e comunitários que nos unem, e que, não raro menosprezados, condenam-nos ao isolamento.

Octavio Paz (1990), analisando as relações de contato entre as literaturas dos países de língua espanhola, reclama da condição de isolamento de muitas delas e da carência do que ele chama de homens-ponte, isto é, autores cujas obras se mostrem capazes de promover diálogos intensos e duradouros com os demias. Tal raciocínio nos remete ao modelo da literatura como um sistema de "vasos comunicantes" (SANTILLI, 1985), a que fizemos alusão no início desse trabalho, pelo qual potencializa-se a idéia de troca constante do fluido literário em todos os sentidos possíveis do sistema.

Tal modelo de relação, perfeitamente ilustrado pelo caso específico da presença da poesia de Bandeira entre os claridosos, aponta para a possibilidade de um questionamento da idéia de centro cultural absoluto, no qual seriam forjados os valores a serem imitados ou seguidos pelas margens do sistema. Ao contrário disso, o estabelecimento de uma relação mútua entre agentes cujos espaços de enunciação encontram-se às margens dos grande centros mundiais de poder funciona como um mecanismo de resistência cultural à homogeneização ou a formas estanques de muticulturalismo, as quais, longe de valorizarem a diversidade, são, na expressão de Lawrence Grossberg, “indiferentes às diferenças” (apud CONNOR, 1993, p. 136).

O movimento da Claridade, pedra de toque da moderna literatura cabo-verdiana, fundamenta-se pela tensão entre a valorização do local e a abertura para o mundo, entre o apregoado "telurismo" ou o "fincar os pés em Cabo Verde" e a ruptura do sentimento de insularidade. Tensão, parece-nos, característica não apenas das literaturas caboverdiana e brasileira, mas de todas as produzidas em espaços coloniais ou pós-coloniais. 
Nesse duplo movimento da literatura cabo-verdiana, isto é, nesse processo dialético de investigar profundamente as próprias raízes culturais para, a partir delas, erigir uma literatura moderna capaz de romper com a condição colonial e insular, a poesia de Bandeira cumpriu um papel decisivo ao apresentar-se como heterogêneo capaz de absorver recursos da cultura popular local e das vanguardas estéticas nascidas do simbolismo europeu.

Ao valorizar o cotidiano, trazendo para dentro do texto registros lingüísticos locais, descobrindo uma pulsão poética natural, de ritmos flexíveis, libertos de regramentos absolutos, Bandeira estendeu com sua poesia uma ponte pela qual muitos outros autores puderam transpor, como ele, a via nem sempre fácil do modernismo; os claridosos, sem cerimônia, empreenderam tal travessia. 
BIBLIOGRAFIAS 


\section{Obras de autores cabo-verdianos ${ }^{34}$}

_ AlCÂNTARA, Osvaldo. Cântico da manhã futura. Praia: Banco de Cabo Verde, 1986.

_ ALMEIDA, José Evaristo d'. O Escravo, Lisboa, ALAC, 1989.

_ANDRADE, Mário Pinto de. (Org.) Antologia Temática da Poesia Africana - Vol 1: Na noite grávida de punhais. Lisboa: Sá da Costa, 1975.

_ BARBOSA, Jorge. Arquipélago. São Vicente: Edições Claridade, 1935. . Ambiente. Praia: Minerva de Cabo Verde, 1941. . Caderno de um ilhéu. Lisboa: Agência Geral do Ultramar, 1956. . Obra Poética. Lisboa: Imprensa Nacional/Casa da Moeda, 2002. [Coleção dos países de língua portuguesa: 29].

_ CARDOSO, Pedro. Sonetos e Redondilhas. Vila Nova de Famalicão: Tipografia Minerva, 1934.

_ CLARIDADE, $\mathrm{N}^{\mathrm{os}} 1,2$ e 3. São Vicente: Cabo Verde, 1936-1937. ${ }^{35}$

_ CLARIDADE, Revista de Cultura e Arte (1936-1960). 2a ed. Lisboa: África Edit./Inst. Port. do Livro e da Leitura, 1986. [Ed. Fac-similar org. por Manuel Ferreira].

_ FERREIRA, Manuel. No Reino de Caliban - Antologia Panorâmica da Poesia Africana. Lisboa, Seara Nova, 1975. 2 vols. . Hora di Bai. São Paulo: Ática, 1980.

_ FIGUEIREDO, Jaime de (sel. e apresentação) Modernos Poetas Cabo-verdianos. Achamento de Cabo Verde: Edições Henriquinas, 1961.

_ FORTES, Corsino. Pão \& Fonema. 2a . ed. Lisboa: Sá da Costa, 1980.

_ LOPES, Baltasar. O dialeto crioulo de Cabo Verde. Lisboa: Imprensa Nacional, 1947. .Chiquinho. São Paulo: Ática, 1986. [Coleção Autores Africanos, 25]

_ LOPES, José. Hesperitanas. Lisboa: J. Rodrigues \& Cia., 1933.

_ LOPES, Manuel. Poemas de quem ficou. Angra do Heroísmo/Açores: Edição do autor, 1949. . Galo Cantou na Baía e Outros Contos. Lisboa: Edições 70, 1984.

_ MARTINS, Ovídio. Gritarei Berrarei Matarei - não vou para Pasárgada. Roterdã: Caboverdianidade, 1973.

\footnotetext{
${ }^{34}$ Inclui antologias e periódicos.
} 
_ PEDRO, António. Diário. Praia: Imprensa Nacional, 1929.

_ TAVARES, Eugénio. Mornas: cantigas crioulas. Lisboa: J. Rodrigues e Cia., 1932.

${ }^{35}$ Consulta a originais do Acervo Mário de Andrade do IEB-USP. 


\section{Obras sobre literatura cabo-verdiana e seus autores}

_ ABDALA Jr, Benjamin. "Utopia e dualidade no contato de culturas - o nascimento da literatura cabo-verdiana", In: Revista USP, $\mathrm{N}^{0} 18$, Dossiê Brasil/África, jun/jul/ago, 1993.

- ALMADA, David Hopffer. Caboverdianidade e tropicalismo. Recife: Fundação Gilberto Freyre, 1992.

_ BARBOSA, Jorge. "Crônicas de São Vicente”, In: Cabo Verde. Praia, Cabo Verde, março de 1953.

_ CABRAL, Amílcar. Obras Escolhidas de Amílcar Cabral. A Arma da Teoria Unidade e Luta I. 2a . Ed. Lisboa: Seara Nova, 1978.

_ CABRAL, Juvenal. Memórias e reflexões. Praia: Imprensa Nacional, 1947.

_CANIATO, Benilde Justo. Hora di Bai: romance de Cabo Verde. São Paulo: FFLCH/USP, 1980. [Dissertação de Mestrado].

. Percursos pela África e por Macau. Cotia/SP: Ateliê,

2005.

- CARDOSO, Pedro. Folclore cabo-verdiano. Paris: Editora Solidariedade Caboverdiana, 1993.

_ FERREIRA, Manuel. A Aventura Crioula. $3^{\mathrm{a}}$. Ed. Lisboa: Plátano Editora, 1985.

- Literaturas Africanas de Expressão Portuguesa, $2^{\mathrm{a}}$ edição.

Lisboa, Instituto de Cultura e Língua Portuguesa, 1986. [Col. Biblioteca Breve, vol. 6].

_ FIGUEIREDO, Jaime de. (Org.) Modernos Poetas Caboverdianos - Antologia. Praia:

Ed. Henriquinas, 1961.

_ FRAGOSO, Francisco. Renunciando Pasárgada... (ou Estudo Diacrônico sobre o Verdadeiro Caminho da Literatura Cabo-verdiana). Louvaina: Ed. do Autor, s.d. (1980).

_ HAMILTON, Russel. Literaturas Africanas. Literaturas Necessárias. Lisboa: Edições 70, 1984. V. II [Biblioteca de Estudos Africanos].

_ LABAN, Michel (org.) Cabo Verde - encontro com escritores. Porto: Fundação Engenheiro António de Almeida, 1992. 2 vols.

_ LARANJEIRA, Pires. Literatura Calibanesca. Porto: Afrontamento, 1985. 
De letra em riste. Porto: Afrontamentos, 1992. [Coleção

Textos, 21]

Literaturas Africanas de Expressão Portuguesa. Lisboa:

Universidade Aberta, 1995.

_ LIMA, Norma Sueli Rosa. Revisitando Claridade: o encantamento da poesia caboverdiana com o modernismo brasileiro. Niterói: Instituto de Letras / UFF, 2000.

_ LOPES, Baltasar. Cabo Verde visto por Gilberto Freyre. Praia, Cabo Verde, 1956.

_ LOPES, Manuel. "Reflexões sobre a literatura cabo-verdiana", In: Colóquios caboverdianos, $\mathrm{N}^{\mathrm{O}} 22$, Lisboa: Junta de Investigação do Ultramar, 1959.

_ MARGARIDO, Alfredo. Estudos sobre Literaturas das Nações Africanas de Língua Portuguesa. Lisboa: A Regra do Jogo, 1980.

_ MARIANO, Gabriel. Cultura Caboverdeana - Ensaios. Lisboa: Veja, 1991. [Col. Palavra Africana].

_ MIRANDA, Nuno de. Compreensão de Cabo Verde. Lisboa: Junta de Investigação do Ultramar, 1963.

_ OLIVEIRA, João Nobre de. A Imprensa Cabo-verdiana 1820 - 1975. Macau: Fundação Macau, 1998.

_ OLIVEIRA, José Osório de. Poesia de Cabo Verde. Lisboa: Agência Geral das Colônias, 1944.

_ PEREIRA, Ana Luísa Ventura. A Oeste das Ilhas, a América - Açores e Cabo Verde numa mesma perspectiva. São Paulo: FFLCH-USP, 1995. [Dissertação de mestrado].

_ ROMANO, Luís. Evocação de Portugal e Presença do Brasil na Literatura Caboverdiana. Mossoró: Secretaria de Educação e Cultura, 1966. [Col. Mossoroense, Série $\left.\mathrm{B}, \mathrm{n}^{\mathrm{o}} 81\right]$.

_ SANTOS, Elsa Rodrigues dos. As Máscaras Poéticas de Jorge Barbosa e a Mundividência Cabo-verdiana. Lisboa: Editorial Caminho, 1989. [Col. Universitária].

- SANTOS, Rubens Pereira dos. Vidas Secas e Os flagelados do vento leste: ínsulamento e tragédia. São Paulo: FFLCH-USP, 1995. [Tese de Doutoramento]

_ SILVEIRA, Onésimo. Consciencialização na Literatura Cabo-verdiana. Lisboa: Casa dos Estudantes do Império, 1963.

_ VÁRIOS. Portuguese Literary and Cultural Studies, 8 (Cape Verde - Language, Literature \& Music). Center for Portuguese Studies and Culture, University of Massachusetts Dartmouth, Spring, 2002. 


\section{Obras de Manuel Bandeira}

_ BANDEIRA, Manuel. Poemas traduzidos. 2ª Ed. Porto Alegre: Globo, 1948. . De poetas e de poesia. Rio de Janeiro: Ministério da Educação

e Cultura, 1954.

. "Versificação em Língua Portuguesa". In: Enciclopédia Delta

Larousse. Rio de Janeiro: Delta Larousse, 1956.

- Obras Poéticas de Manuel Bandeira, Lisboa: Editorial

Minerva, 1956. b . Apresentação da Poesia Brasileira. $3^{\mathrm{a}}$. ed. Rio de Janeiro: Casa dos Estudantes, 1957.

Poesia e Prosa. Rio de Janeiro: Aguilar, 1958, 2 vols.

. "Raimundo Correa e o sortilégio verbal", in Introdução a

Raimundo Correia - Poesia Completa e Prosa. Rio de Janeiro: Aguilar, 1961, pp. 1232.

. Estrela da Vida Inteira. Rio de Janeiro: José Olympio, 1966. a
. Estrela da Vida Inteira. $20^{\mathrm{a}}$. ed. Rio de Janeiro: Nova Fronteira, 1993.

Andorinha, Andorinha. Rio de Janeiro, José Olympio, 1966. b

[Seleção de textos e coordenação: Carlos Drummond de Andrade].

Fronteira, $1984 .^{36}$

- Itinerário de Pasárgada, $5^{\mathrm{a}}$ edição. Rio de Janeiro: Nova

_ BANDEIRA, Manuel (Org.) Obras poéticas de Gonçalves Dias. Rio de Janeiro:

Companhia Editora Nacional, 1944.

\footnotetext{
${ }^{36}$ Primeira edição de 1954, preparada a pedido de Fernando Sabino e Paulo Mendes Campos.
} 


\section{Obras sobre Manuel Bandeira}

_ ANDRADE, Mário de. “A Poesia de 1930”. In: Aspectos da Literatura Brasileira. São Paulo: Martins, s.d., pp. 27-45.

_ ARRIGUCCI Jr, Davi. Humildade, Paixão e Morte - A Poesia de Manuel Bandeira. São Paulo: Companhia das Letras, 1992.

_ BACIU, Stefan. Manuel Bandeira de corpo inteiro. Rio de Janeiro: José Olympio, 1966.

_ BRAYNER, Sônia. (Org.) Manuel Bandeira. Rio de Janeiro: Civilização Brasileira/INL-MEC, 1980. [Fortuna Crítica, 5].

_ COELHO, Joaquim-Francisco. Manuel Bandeira Pré-Modernista. Rio de Janeiro: José Olympio, 1982.

_ COUTO, Ribeiro. Dois Retratos de Manuel Bandeira. Rio de Janeiro: São José, 1960.

_ FONSECA, Edson Nery da. Alumbramento e Perplexidades. Vivências Bandeirianas. São Paulo: ARX, 2002.

_ GARBUGLIO, José Carlos. Bandeira entre o beco e a Pasárgada. Poitiers: Centre de Recherches Latino-américaines, 1974.

_ GOLDSTEIN, Norma. Do Penumbrismo ao Modernismo - O Primeiro Bandeira e outros Poetas Significativos. São Paulo: Ática, 1983.

_ GOLDSTEIN, Norma (Org.) Traços marcantes no percurso poético de Manuel Bandeira. São Paulo: Humanitas, 2005.

_ HOLANDA, Sérgio Buarque de. "Trajetória de uma Poesia”. In: Cobra de Vidro, $2^{\mathrm{a}}$.ed. São Paulo: Perspectiva, 1978. pp.

_ LOPEZ, Telê Porto Ancona (org.) Manuel Bandeira: Verso e Reverso. São Paulo: T. A. Queiroz, 1987.

_ MONTEIRO, Adolfo Casais. Manuel Bandeira. Rio de Janeiro: MEC, 1958. [Cadernos de Cultura, 111].

_ MORAES, Marcos Antônio de. (Org.) Correspondência Mário de Andrade \& Manuel Bandeira. São Paulo: Edusp, 2001.

_ RIBEIRO, João. "A cinza das horas" e "Carnaval”. In: Crítica. Os Modernos. Rio de Janeiro: Academia Brasileira de Letras, 1952. pp. 66-77. 
_ ROSENBAUM, Yudith. Manuel Bandeira: uma poesia da ausência. São Paulo: Imago/Edusp, 1993.

_ SOUZA, Gilda e Antonio Candido de Mello e. "Introdução". In: BANDEIRA, Manuel. Estrela da Vida Inteira. Rio de Janeiro: José Olympio, 1966. pp. I-XX.

_ VÍTOR, Nestor. Cartas à Gente Nova. Rio de Janeiro: Anuário do Brasil, 1923. 


\section{Obras Gerais}

_ ABDALA Jr, Benjamim. "Crioulidade e identidade nas literaturas de Língua Portuguesa", In: Simpósio de Literatura Comparada. Belo Horizonte: UFMG, 1987.

. "Estudos comparados de literaturas de língua portuguesa: perspectivas político-culturais", In: Metamorfoses 1, Rio de Janeiro: UFRJ/Edições Cosmos, 2000. . De vôos e ilhas. Literatura e comunitarismos. Cotia/SP:

Ateliê, 2003. . (Org.) Margens da Cultura. São Paulo: Boitempo

Editorial, 2004.

- AlBUQUERQUE, Luís \& SANTOS, Maria Emília Madeira (Coords.). História Geral de Cabo Verde. Lisboa / Praia: Centro de Estudos de História e Cartografia Antiga, Instituto de Investigação Científica Tropical / Direcção Geral do Patrimônio Cultural de Cabo Verde, 1995.

_ ALBUQUERQUE, Orlando de. Crioulismo e Mulatismo (Uma tentativa de interpretação fenomenológica). Lobito: Capricórnio, 1976.

_ ALMEIDA, Guilherme de. Meu Portugal. São Paulo: Nacional, 1933.

_ AMARAL, Aracy. Blaise Cendrars no Brasil e os modernistas. São Paulo: Martins, 1970.

_ ANDERSON, Benedict. Nação e consciência nacional. São Paulo, Ática, 1986.

_ ANDRADE, Carlos Drummond de. Passeios na ilha. Rio de Janeiro: Simões, 1952. Reunião: 10 livros de poesia. Rio de Janeiro: José

Olympio, 1969.

_ ANDRADE, Mário de. O Movimento Modernista. Rio de Janeiro: Casa do Estudante, 1942. . A Lição do Amigo. Cartas de Mário de Andrade a Carlos

Drummond de Andrade. Rio de Janeiro: José Olympio, 1982.

_ ANDRADE, Mário Pinto de. Origens do nacionalismo africano. Lisboa, Dom Quixote, 1997.

_ ATAÍDE, Trisão. Estudos, 2a ${ }^{\text {a }}$ série, Rio de Janeiro: Terra do Sol, 1928.

_ ÁVILA, Affonso (Org.) O modernismo. São Paulo: Perspectiva, 1975. 
_ BACHELARD, Gaston. La poétique de l'espace. Paris: Puf, 1957.

. A Água e os Sonhos - ensaio sobre a imaginação da matéria.

Trad.: Antônio de Pádua Danesi. São Paulo, Martins Fontes, 1989. . Dialectique de la Durée. Paris: Quadrige/PUF, 1989. b

_ BAKHTIN, Mikhail. Le principe dialogique. Paris : Seuil, 1981.

_ BAKHTIN, Mikhail (V. N. Volochínov). Marxismo e Filosofia da Linguagem. Problemas Fundamentais do Método Sociológico na Ciência da Linguagem. $8^{a}$ ed. São Paulo : Hucitec, 1997.

_ BALAKIAN, Anna. O Simbolismo. Trad.: José B. Caldas. São Paulo: Perspectiva, 1985.

_ BARTHES, Roland. L’Aventure Sémiologique. Paris: Seuil, 1985.

_ BASTIDE, Roger. A poesia afro-brasileira. São Paulo: Martins, 1943. . Poetas do Brasil. São Paulo: Edusp/Duas Cidades, 1997.

_ BENJAMIN, Walter. Magia e Técnica. Arte e Cultura. $4^{\mathrm{a}}$ ed. São Paulo, Brasiliense, 1990.

_ BERRINI, Beatriz. Utopia, Utopias. São Paulo, Educ, 1997.

_ BHABHA, Homi K. O Local da Cultura. 2a reimp. Belo Horizonte, UFMG, 2003. [Humanitas, 25].

_ BILAC, Olavo. Poesias. Rio de Janeiro: F. Alves, 1946.

_ BLOCH, Ernst. The Utopian Function of Art and Literature, Cambridge: MIT Press, 1988

Le principe espérance. Tome I, II, III. Paris, Gallimard, 1976, 1982, 1992.

_ BLOOM, Harold. The Anxiety of Influence: a theory of poetry. New York / London: Oxford University Press, 1975.

_ BONNAFÉ, Pierre. Le Nationalisme Africain - aperçues sur sa naissance et son developpement. Paris, Centre détudes des relations internationals, 1964. [Série C, Recherches, No. 9, déc, 1964].

_ BOPP, Raul. Movimentos Modernistas no Brasil. 1922-1928. Rio de Janeiro: Livraria São José, 1966.

_ BORGES, Jorge Luis. Esse ofício do verso. Trad.: José Marcos Macedo. São Paulo: Companhia das Letras, 2001.

_ BOSI, Alfredo. O Ser e o Tempo da Poesia. São Paulo, Cultrix / Edusp, 1977. 
. "Moderno e modernista no Brasil”, In: Céu, Inferno. São Paulo:

Ática, 1988. . História Concisa da Literatura Brasileira. 32a . ed. São Paulo:

Cultrix, 1994.

- . "Sobre alguns modos de ler poes
Leitura de Poesia. São Paulo: Ática, 1996. pp. 7-48.

. Dialética da Colonização, $3^{\mathrm{a}}$. ed., São Paulo, Companhia das Letras, 1996. b

_ BOURDIEU, Pierre. O poder simbólico. Lisboa/Rio de Janeiro, Difel/Bertrand do Brasil, 1989.

_ BRITO, Mário da Silva. História do Modernismo Brasileiro. Antecedentes da Semana de Arte Moderna. 6a . ed. Rio de Janeiro: Civilização Brasileira, 1997.

_ BRUNEL, P. \& CHEVREL, Y. (Orgs.). Précis de Litterature Comparée. Paris, PUF, 1985.

_ CAMARA Jr., J. Mattoso. Contribuição à Estilística Portuguesa. 3 ed.rev., Rio de Janeiro: Ao Livro Técnico/MEC, 1977.

_ CANDIDO, Antonio. Literatura e Sociedade. Estudos de Teoria e História Literária. São Paulo, Companhia Editora Nacional, 1964. [Coleção Ensaio, 5] . Na sala de aula. Caderno de análise literária. São Paulo: Ática, 1985.

. O Estudo Analítico do Poema, $3^{\text {a }}$ ed., São Paulo, Humanitas, 1999.

_ CARVALHO, Ronald de. Estudos brasileiros. 2a . série, RJ: F. Briguiet, 1931.

_ CENDRARS, Blaise. Kodak. Paris: Stock, 1924.

_ CHEVAlIER, Jean \& GHEERBRANT, Alain. Dicionário de Símbolos. 2a . Ed. Rio de Janeiro: Nova Fronteira, 1989.

_ CIONARESCU, Alexandre. L'Avenir du Passé. Paris, Gallimard, 1972. [Les Essais, CLXXI].

_ COHEN, Jean. Estrutura da linguagem poética. 2a . ed. São Paulo: Cultrix, 1978.

_ CONNOR, Steven. Cultura Pós-moderna - Introdução às teorias do contemporâneo.

$2^{a}$ ed. Trad.: Adail Ubirajara Sobral e Maria Stela Gonçalves. São Paulo: Loyola, 1993.

_ COUTINHO, Afrânio et alii. A literatura no Brasil. Rio de Janeiro: Sul Americana, 1969. 
_ COUTINHO, Eduardo \& CARVALHAL, Tânia (Orgs.). Literatura Comparada: Textos Fundadores. Rio de Janeiro: Rocco, 1994.

_ COUTO, Rui Ribeiro. Poesias reunidas. Rio de Janeiro: J. Olympio, 1960. . Sentimento Lusitano. São Paulo: Martins, 1961.

_ DELEUZE, Gilles \& GUATTARI, Félix. Mil Platôs - Capitalismo e Esquizofrenia. Trad.: Aurélio G. Neto e Célia P. Costa. Rio de Janeiro: Editora 34, 1995. Vol. 1.

_ DERRIDA, Jacques. Marges de la Philosophie. Paris: Éditions de Minuit, 1972.

_ DIAS, Gonçalves. Poesias de A. Gonçalves Dias. T. II. Rio de Janeiro: Garnier, 1926.

_ DUFRENNE, Mikel. O Poético. Porto Alegre, Globo, 1969.

_ FANON, Frantz. Os Condenados da Terra. Trad.: José Laurêncio de Melo. Rio de Janeiro: Civilização Brasileira, 1968.

_ FIGUEIREDO, Jackson de. Do Nacionalismo na Hora Presente. Rio de Janeiro: Livraria Católica, 1921.

_ FREYRE, Gilberto. Casa Grande \& Senzala. Rio de Janeiro: Maria Schimidt, 1933. . Manifesto Regionalista. Recife: Região, 1952.

_ _ Um Brasileiro em Terras Portuguesas. Rio de Janeiro: José Olympio, 1953. Aventura e Rotina. Lisboa: Livros do Brasil, 1953. b

- _ Integração Portuguesa nos Trópicos. Lisboa: Ministério do Ultramar, 1958. . Novo Mundo nos Trópicos. São Paulo: CEN/Edusp, 1971. [Col. Brasiliana, 348].

_ GARCIA CANCLINI, Néstor. "La épica de la globalización y el melodrama de la interculturalidad". In: MORAÑA, Mabel (org.) Nuevas perspectivas desde/sobre América Latina. Santiago: Editorial Cuarto Proprio, 2000.

. Culturas Híbridas. $4^{\mathrm{a}}$ ed. São Paulo: Edusp, 2003.

[Ensaios Latino-americanos, 1].

_ GLISSANT, Édouard. Poétique de la Relation. Paris: Gallimard, 1990. . Introduction à une poétique du divers. Paris: Gallimard, 1996. . Traité du tout-monde. Paris: Gallimard, 1997.

_ GOES, Fernando. “O Simbolismo”, In: Panorama da Poesia Brasileira. São Paulo: Civilização Brasileira, 1959, v. 4.

_ GRAMSCI, Antônio. Cadernos do Cárcere. Trad.: Carlos Coutinho, Luiz Henriques e Marco Aurélio Nogueira. Rio de Janeiro: Civilização Brasileira, 1999. 6 vols. 
_ GRUZINSKI, Serge. O Pensamento Mestiço. Trad.: Rosa Freire d'Aguiar. São Paulo, Companhia das Letras, 2001.

_ GUILLÉN, Claudio. Entre lo Uno y lo Diverso. Introducción a la Literatura Comparada. Barcelona: Editorial Crítica, 1985.

_ HALL, Stuart. Da Diáspora - Identidades e Mediações Culturais. Belo Horizonte: UFMG / Brasília: Unesco, 2003. [Coleção Humanitas, 93]

_ HAUSER, Arnold. Historia Social de la Literatura y del Arte. Madrid: Guadarrama, 1968. V. 3.

_ HOBSBAWN, Eric J. Nações e Nacionalismo desde 1780 - programa, mito e realidade. $2^{\text {a }}$.ed. São Paulo, Paz \& Terra, 1998. [Trad.: Maria Célia Paoli e Anna M. Quirino].

_ HOLANDA, Sérgio Buarque de. Visão do Paraíso. 6a. ed. São Paulo: Brasiliense, 1999.

_ JAKOBSON, Roman. Lingüística e Comunicação. Trad.: Izidoro Blikstein e José Paulo Paes. São Paulo: Cultrix, 1969.

_ JAUSS, Hans Robert. Pour une Esthétique de la Recepcion. Trad.: Claude Maillard. Paris: Gallimard, 1978.

• "A Estética da Recepção: colocações gerais", In: COSTA, Lima

(org.). A Leitura e o Leitor. Textos de Estética da Recepção. Rio de Janeiro: Paz e Terra, 1979.

__LAFETÁ, João Luiz. 1930: a crítica e o modernismo. São Paulo: Duas Cidades, 1974. _ LESSA, Luís Carlos. O modernismo brasileiro e a língua portuguesa. Rio de Janeiro: Agir, 1966.

_ LEVIN, Samuel. Estruturas Lingüísticas em Poesia. Tradução: José Paulo Paes. São Paulo, Cultrix/Edusp, 1975.

_ LEVITAS, Ruth. The Concept of Utopia. New York: Ph. Allan, 1990.

_ LIMA, Jorge de. Obra Completa. Rio de Janeiro: J. Aguilar, 1958.

_ LOURENÇO, Eduardo. Mitologia da Saudade. São Paulo, Companhia das Letras, 1999.

_ MARTINS, Wilson. A Literatura Brasileira: o Modernismo. 1916-1945. 2a . ed. São Paulo: Cultrix, 1967, v. 6.

_ MATTOSO CÂMARA, Joaquim. Dicionário de Língüística e Gramática. 16 .ed., Petrópolis: Vozes, 1992. 
_ MEDEIROS, Maria Alice de Aguiar. Elogio da Dominação - Relendo Casa Grande \& Senzala. Rio de Janeiro: Achamé, 1984.

_ Merriam-Webster's Encyclopedia of Literature. Springfield, Massachusetts: MerriamWebster, 1995.

_ MORE, Thomas. Utopia. $2^{\text {a }}$. ed. Trad.: Jefferson Luiz Camargo e Marcelo Brandão Cipolla. São Paulo: Martins Fontes, 1999.

_ MOSER, Walter. "La culture postmoderne entre le congédiement de l'utopie et le retour de la mélancolie". http://www.fas.umontreal.ca/littco/spaetzeit/ s./d.

_ MÜNSTER, Arno. Ernst Bloch: Filosofia da Práxis e Utopia Concreta. São Paulo: Unesp, 1993.

_ MURICY, Andrade. Panorama do Movimento Simbolista Brasileiro. Rio de Janeiro: Instituto Nacional do Livro, 1952. 3 vols.

_ OLIVEIRA, José Osório de. Literatura Brasileira. Lisboa: Lumen Empresa Internacional Editora, 1926.

. Pequena antologia da moderna poesia brasileira. Lisboa:

S. P. N, 1944.

_ OLIVEIRA VIANNA, Francisco José de. Populações meridionais do Brasil. $7^{\mathrm{a}}$ ed.

Belo Horizonte: Itatiaia / Niterói: Universidade Federal Fluminense, 1987. 2 vols.

_ ORTIZ, Fernando. Contrapunteo Cubano del Tabaco y del Azúcar. 2a . ed., Havana: Consejo Nacional de Cultura, 1963.

_PAZ, Octavio. In /mediaciones. 3 $3^{\text {a }}$ ed. Barcelona: Seix Barral, 1990.

_ PLATÃO. A República. $7^{\mathrm{a}}$. ed. Trad.: Maria Helena Pereira. Lisboa: Fundação Calouste Gulbenkian, 1993.

_ RAMA, Ángel. "Os processos de transculturação na narrativa latino-americana”, in: AGUIAR, Flávio \& VASCONCELOS, Sandra. Ángel Rama - Literatura e Cultura na América Latina. São Paulo: Edusp, 2001. [Ensaios Latino-americanos, 6].

_ RAMOS, Péricles Eugênio da Silva. Poesia Simbolista. São Paulo: Melhoramentos, 1965.

_ RICOEUR, Paul. Ideologia e Utopia. Lisboa: Edições 70, 1991.

_ SANTIAGO, Silviano. Uma Literatura nos Trópicos - Ensaios sobre dependência cultural. São Paulo, Perspectiva, 1978.

_ SANTILLI, Maria Aparecida. Africanidade - contornos literários. São Paulo: Ática, 1985. 
_ SANTOS, Boaventura de Sousa. Pela mão de Alice: o social e o político na pósmodernidade. Porto: Afrontamento, 1992.

. "Between Prospero and Caliban: colonialism, postcolonialism, and inter-identity", In: Luso-Brazilian Review, volume 39, number 2, Winter 2002. University of Wisconsin Press. pp. 9-43.

_ SARAIVA, António José \& LOPES, Óscar. História da Literatura Portuguesa. 20ª ed. Martins: Europa América, 1999.

_ SARAIVA, Arnaldo. Modernismo Brasileiro e Modernismo Português. Subsídios para o seu estudo e para a história das suas relações. Campinas: Editora da Unicamp, 2004.

_ SARTRE, Jean Paul. “Orphée Noir”. In: SENGHOR, Léopold (Org.) La Nouvelle Poésie Nègre at Malgache. Paris: Presse Universitaire de France, 1948. pp. IX-XLIV

_ SAUSSURE, Ferdinand de. Curso de Lingüística Geral. Trad.: Antônio Chelini, José Paulo Paes e Izidoro Blikstein. São Paulo : Cultrix / Edusp, 1969.

_ TELLES, Gilberto Mendonça. Vanguardas Européias e Modernismo Brasileiro. $6^{\mathrm{a}}$. ed. Petrópolis: Vozes, 1982.

_ THIBAUDET, Albert. Le liseur de romans. Paris: G. Crès \& Cie, 1925.

_ TODOROV, Tzvetan. "Teorias da Poesia”, in: O Discurso da Poesia, Coimbra, Almedina, 1982. pp. 7-14.

_ TOLEDO, Dionísio de Oliveira (Org.). Teoria da Literatura: Formalistas Russos, Porto Alegre: Editora Globo, 1971.

_ TORRE, Guillermo de. Historia de las literaturas de vanguardia. Madrid: Ediciones Guadarrama, 1971.

_ TORRES, Antônio. As razoens da inconfydencia. Rio de Janeiro: A. J. Castilho, 1925.

_ TRIGO, Salvato. Ensaios de Literatura Comparada (Afro-luso-brasileira). Lisboa: Veja, s./d.

_ TYNIANOV, Youri. "Os traços flutuantes da significação do verso”. In: $O$ discurso da poesia. Coimbra: Almedina, 1982. pp. 15-27.

- VERÍSSIMO, José. Estudos de Literatura Brasileira, Sexta Série, Rio de Janeiro: Garnier, 1907.

_ VERLAINE, Paul. Oeuvres poétiques completes. Paris: Gallimard, 1954.

_ VILHENA, Ernesto. Aventura e Rotina: crítica de uma crítica. Lisboa, 1955.

_ VÍTOR, Nestor. Crítica de ontem. Rio de Janeiro: Leite Ribeiro \& Maurílio, 1919. . Cartas à Gente Nova. Rio de Janeiro: Anuário do Brasil, 1923. 